\title{
Characterization of Organic Matter in Lake Sediments from Minnesota and Yellowstone National Park
}

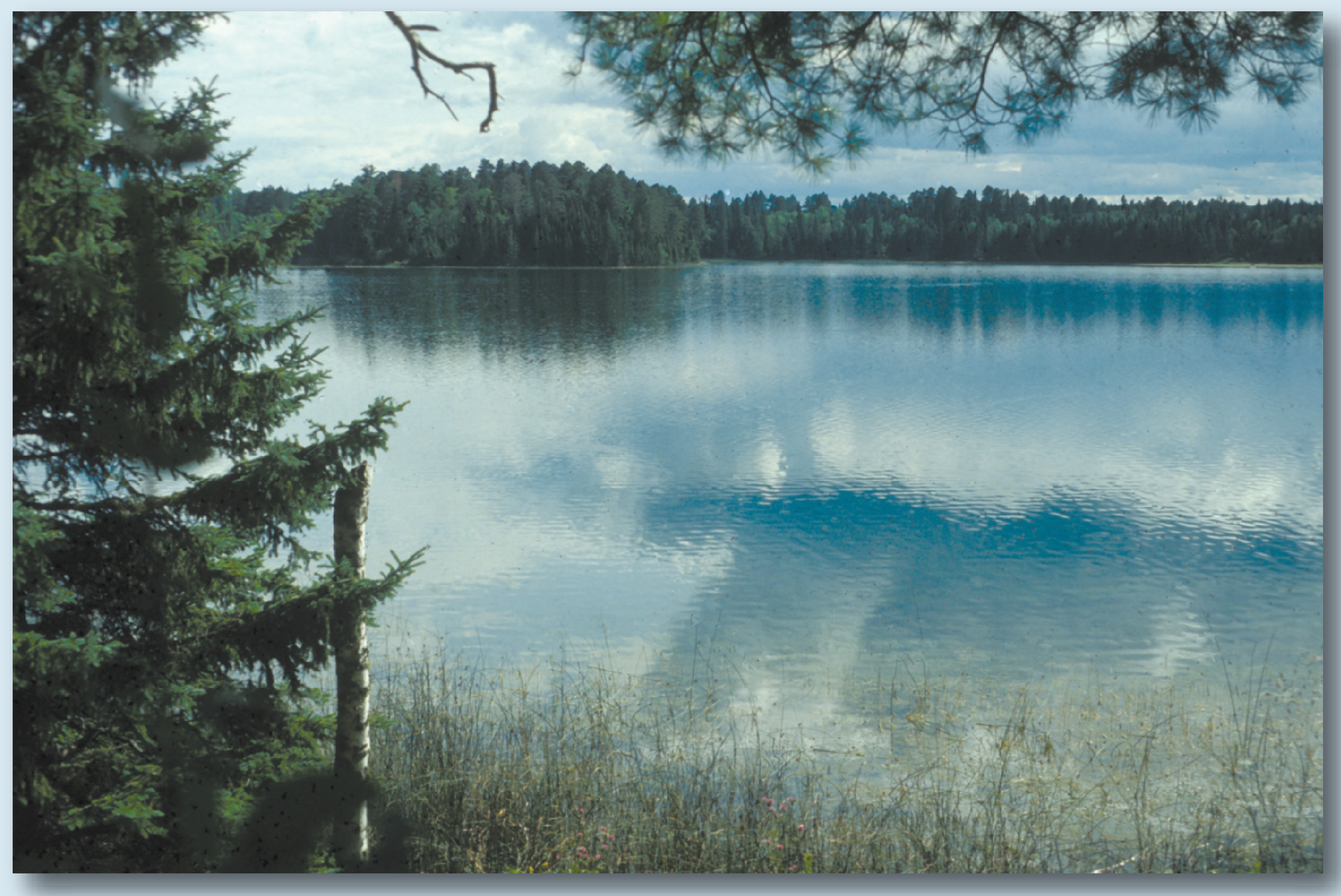

Elk Lake, Minnesota, is typical of the many lakes in glaciated parts of the Midwestern United States.

Open-File Report 2006-1053 


\section{Characterization of Organic Matter in Lake Sediments from Minnesota and Yellowstone National Park}

By Walter E. Dean

Open-File Report 2006-1053 


\title{
U.S. Department of the Interior \\ Gale A. Norton, Secretary
}

\section{U.S. Geological Survey \\ P. Patrick Leahy, Acting Director}

\author{
U.S. Geological Survey, Reston, Virginia: 2006 \\ Version 1.0
}

\author{
This publication is only available online at \\ http://pubs.usgs.gov/of/2006/1053 \\ For more information on the USGS — the Federal source for science about the Earth, its natural and living resources, \\ natural hazards, and the environment: \\ World Wide Web: http://www.usgs.gov \\ Telephone: 1-888-ASK-USGS
}

\begin{abstract}
Any use of trade, product, or firm names is for descriptive purposes only and does not imply endorsement by the U.S. Government.

Although this report is in the public domain, permission must be secured from the individual copyright owners to reproduce any copyrighted materials contained within this report.
\end{abstract}

Suggested citation:

Dean, W.E., 2006, Characterization of organic matter in lake sediments from Minnesota and Yellowstone National Park: U.S. Geological Survey Open-File Report 2006-1053, 40 p. 


\section{Contents}

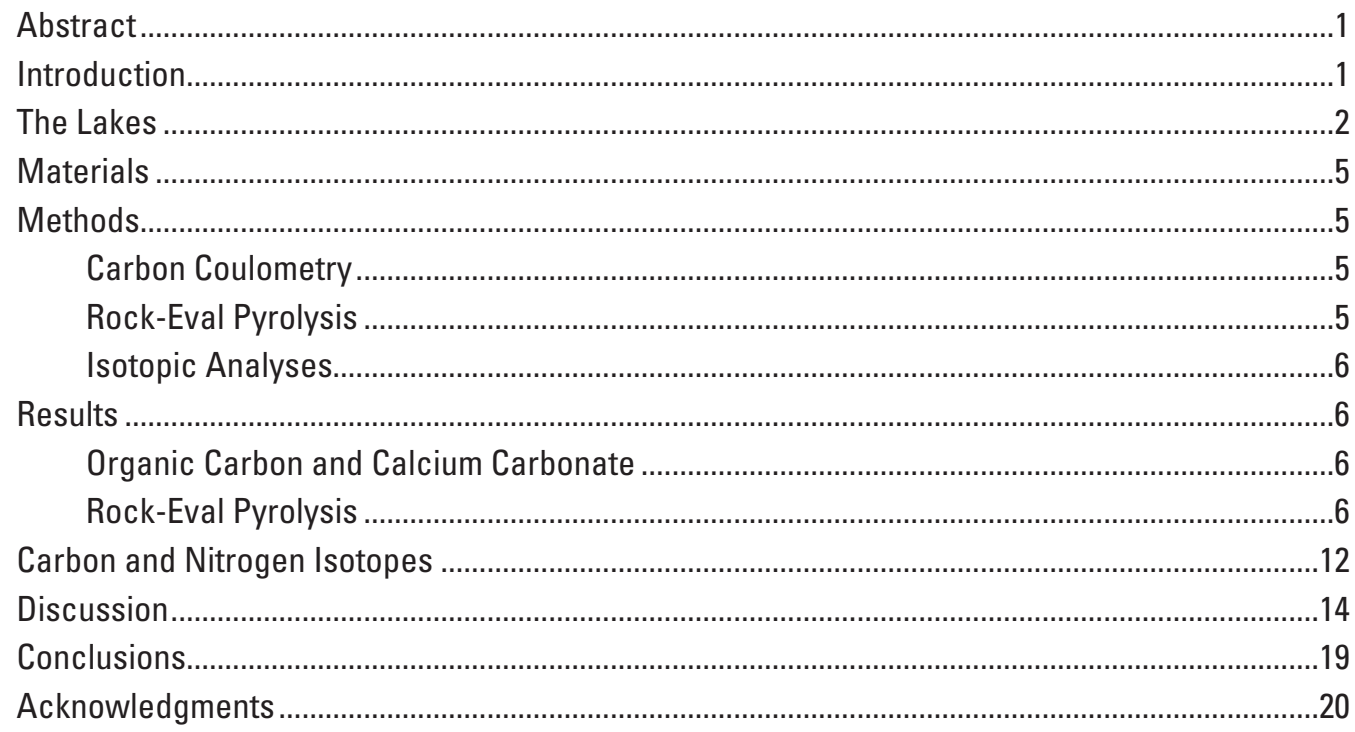

\section{Figures}

1. Map of Minnesota and adjacent North and South Dakota showing the

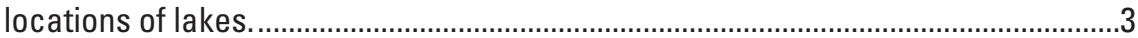

2. Map of Yellowstone National Park showing the locations of lakes............................4

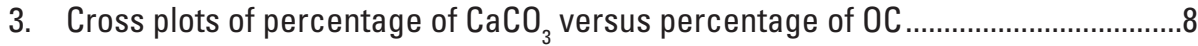

4. Cross plots of Rock-Eval pyrolysis oxygen index versus hydrogen index for samples of Minnesota lake sediments.................................................................9

5. Cross plot of Rock-Eval pyrolysis oxygen index versus hydrogen index for samples of sediments from lakes in Yellowstone National Park ..............................10

6. Cross plots of percentage of OC versus Rock-Eval pyrolysis S2 peak height........11

7. Ranges of values of $\delta^{13} \mathrm{C}$ in various plant materials and organic matter

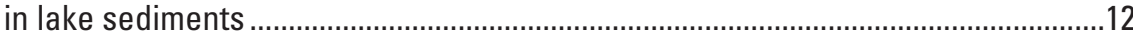

8. Ranges of values of $\delta^{15} \mathrm{~N}$ in various nitrogen bearing pools and in

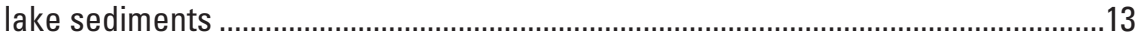

9. Cross plots of Rock-Eval pyrolysis hydrogen index versus values $\delta^{13} \mathrm{C}$

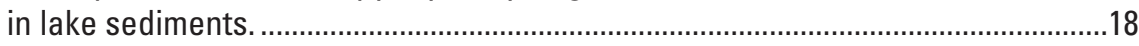

10. Values of Rock-Eval pryolysis hydrogen index $(\mathrm{HI})$ and ${ }^{13} \mathrm{C}$ of organic matter in sediments in Lake Greifen, Switzerland

\section{Appendix Tables}

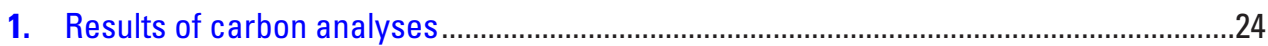

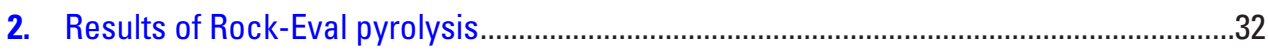

3. Results of carbon and nitrogen isotope analyses ............................................................ 


\title{
Characterization of Organic Matter in Lake Sediments from Minnesota and Yellowstone National Park
}

\author{
By Walter E. Dean
}

\section{Abstract}

Samples of sediment from lakes in Minnesota and Yellowstone National Park (YNP) were analyzed for organic carbon (OC), hydrogen richness by Rock-Eval pyrolysis, and stable carbon- and nitrogen-isotope composition of bulk organic matter. Values of $\delta^{13} \mathrm{C}$ of lake plankton tend to be around -28 to -32 parts per thousand $(\% o)$. Organic matter with values of $\delta^{13} \mathrm{C}$ in the high negative 20s overlap with those of organic matter derived from $\mathrm{C} 3$ higher terrestrial plants but are at least $10 \%$ more depleted in ${ }^{13} \mathrm{C}$ than organic matter derived from $\mathrm{C} 4$ terrestrial plants. If the organic matter is produced mainly by photosynthetic plankton and is not oxidized in the water column, there may be a negative correlation between $\mathrm{H}$-richness (Rock-Eval pyrolysis $\mathrm{H}$-index) and $\delta^{13} \mathrm{C}$, with more $\mathrm{H}$-rich, algal organic matter having lower values of $\delta^{13} \mathrm{C}$. However, if aquatic organic matter is oxidized in the water column, or if the organic matter is a mixture of terrestrial and aquatic organic matter, then there may be no correlation between H-richness and carbon-isotopic composition. Values of $\delta^{13} \mathrm{C}$ lower than about $-28 \%$ probably indicate a contribution of bacterial biomass produced in the hypolimnion by chemoautotrophy or methanotrophy. In highly eutrophic lakes in which large amounts of ${ }^{13} \mathrm{C}$-depleted organic matter is continually removed from the epilimnion by photosynthesis throughout the growing season, the entire carbon reservoir in the epilimnion may become severely ${ }^{13} \mathrm{C}$-enriched so that ${ }^{13} \mathrm{C}$-enriched photosynthetic organic matter may overprint ${ }^{13} \mathrm{C}$ depleted chemosynthetic bacterial organic matter produced in the hypolimnon.

Most processes involved with the nitrogen cycle in lakes, such as production of ammonia and nitrate, tend to produce ${ }^{15} \mathrm{~N}$-enriched values of $\delta^{15} \mathrm{~N}$. Most Minnesota lake sediments are ${ }^{15} \mathrm{~N}$-enriched. However, some of the more OC-rich sediments have $\delta^{15} \mathrm{~N}$ values close to zero $\left(\delta^{15} \mathrm{~N}\right.$ of air), suggesting that organic matter production is by nitrogen fixation, which further implies that nitrogen is limiting. Most lakes from YNP also have values of $\delta^{15} \mathrm{~N}$ near zero.

\section{Introduction}

The sediments of moderately to highly productive (mesotrophic to eutrophic) temperate zone lakes underlain by sedimentary rocks typically contain olive-green sediments rich in organic matter (usually greater than 20 percent organic matter by loss on ignition at $550^{\circ} \mathrm{C}$, or greater than 10 percent organic carbon) called gyttja (Hansen, 1959). Because many of these lakes are in basins underlain by calcareous glacial drift, they contain calcium-magnesium-bicarbonate-rich ("hard") waters and precipitate calcium carbonate $\left(\mathrm{CaCO}_{3}\right)$, mostly as lowmagnesium calcite, during the late summer. This $\mathrm{CaCO}_{3}$ may dilute the concentration of organic matter somewhat and produce a calcareous sediment called marl (Dean, 1981). For reasons discussed herein, most of the organic matter in gyttja and marl is autochthonous, produced by phytoplankton and aquatic macrophytes in the lake. This conclusion is contrary to a common perception that the organic matter in most temperate lakes is derived from terrestrial sources (for example, Mackereth, 1966; Brunskill and others, 1971; Molot and Dillon, 1996). In some eutrophic lakes, particularly those with a seasonally anoxic hypolimnion, bacterial processes in the hypolimnion may contribute a significant amount of bacterial biomass to the total organic matter delivered to the sediments.

Plant pigment studies of Minnesota lake sediments (Sanger and Gorham, 1970; Gorham and Sanger, 1975) showed that most of the organic matter in an average Minnesota lake is autochthonous, and that only in the least productive lakes in Precambrian bedrock in the arrowhead region of northeastern Minnesota does allochthonous terrestrial organic matter make significant contributions to sedimentary organic matter. Autochthonous organic matter is enriched in proteinaceous, low molecular weight, $\mathrm{H}$ - and $\mathrm{N}$-rich compounds with low $\mathrm{C} / \mathrm{N}$ ratios (typically less than 10; Meyers and Ishiwatari, 1993). Allocthonous terrestrial organic matter is enriched in humic, high molecular weight, $\mathrm{C}$-rich compounds and $\mathrm{C} / \mathrm{N}$ ratios tend to be much higher, with values typically between 20 and 30 (Meyers and Ishiwatari, 1993). The average OC 
(organic carbon) concentration in the sediments of 46 lakes considered to be representative of lakes throughout Minnesota is 12 percent (range 3-29 percent; Dean and others, 1993). The average $\mathrm{OC} / \mathrm{N}$ ratio in the sediments of those $46 \mathrm{Min}-$ nesota lakes is 9.0 (range 7.6-14), and the only sediments with $\mathrm{OC} / \mathrm{N}$ ratios greater than 11 were from 5 of 10 lakes in northeastern Minnesota.

Plant pigment analyses of sediments from lakes in the English Lake District demonstrated that most of the organic matter in those lakes, as in the Minnesota lakes, was autochthonous (Gorham and others, 1974). The average OC concentration in the English lakes is 7.0 percent (range 4.0-13 percent) and the average $\mathrm{OC} / \mathrm{N}$ ratio is 12.2 (range 9.4-14.1) with little variation between lake productivity groups (Dean and others, 1988).

Most of the organic matter in sediments in the depositional basins of the Great Lakes is autochthonus (plankton), has OC concentrations greater than 1 percent, and OC/N ratios of 7-9 (Kemp and others, 1977; Meyers and Ishiwatari, 1993). Glacial-age sediment in the Great Lakes with little organic matter has OC/N ratios greater than 16 (Kemp and others, 1977). Organic contents and OC/N ratios measured in sediments in cores from three Wisconsin Lakes range from 4.4 to 18 percent and 8.5 to 11.3 , respectively, with no significant differences between eutrophic, mesotrophic, and oligotrophic productivity levels (Konrad and others, 1970). Most of the cited examples are from lakes in glaciated areas underlain by sedimentary bedrock. The importance of geology to autochthonous productivity is that glacial drift produced from sedimentary bedrock is more likely to be rich in plant nutrients, especially phosphorus, relative to drift produced by crystalline igneous or metamorphic bedrock. High concentrations of organic matter in the Experimental Lakes Area (ELA) on the Precambrian shield of northwestern Ontario $(\mathrm{OC}=20 \pm 7)$ are due to lack of clastic and carbonate dilution rather than high productivity, but this organic matter still retains $\mathrm{OC} / \mathrm{N}$ ratios (average $=9.7$ ) typical of autochthonous organic matter in more southern lakes on glaciated sedimentary strata (Brunskill and others, 1971).

These previous studies, based mainly on plant pigment analyses and $\mathrm{OC} / \mathrm{N}$ ratios, suggest that most of the organic matter in all but the most oligotrophic lakes is autochthonous, with $\mathrm{OC} / \mathrm{N}$ ratios mostly less than 10 . The slightly elevated values in some oligotrophic northeastern Minnesota lakes and some oligotrophic English lakes may reflect a slightly higher component of allocthonous terrestrial vegetation than in most mesotrophic to eutrophic lakes.

For this investigation, several other geochemical techniques were used to characterize organic matter in lakes with potentially variable sources of organic matter in order to determine if they can improve our understanding of sources of organic matter in lake sediments and the effects of depositional and diagenetic conditions on the quantity and quality of that organic matter. I examined the organic matter in sediments from cores of seven lakes along the Mississippi River valley in Minnesota (fig. 1) with OC concentrations ranging from 2 percent to 35 percent. Pickerel Lake is in eastern South Dakota just across the border with Minnesota and has many of the characteristics of the lakes of the Northern Great Plains in northwestern Minnesota. Organic matter was also examined in Holocene sediments from long cores from four lakes with basins in the diverse bedrock of Yellowstone National Park (YNP) and in surface sediments from eight other lakes throughout YNP (fig. 2) with OC concentrations ranging from 4 percent to 16 percent. Techniques used include: (1) measurement of total and inorganic carbon (and organic carbon by difference); (2) measures of the hydrogen and oxygen richness of the organic matter by Rock-Eval pyrolysis of bulk sediment; and (3) stable carbon- and nitrogen-isotope composition of the bulk organic fraction. Not all techniques were applied to all samples.

Results from Rock-Eval pyrolysis should provide information on the type of organic matter in terms of its hydrogen (hydrocarbon) richness. Carbon-isotope composition should provide information about sources of organic matter in terms of whether it is aquatic or terrestrial, and, if aquatic, was it produced by photoautotrophs in the epilimnion, or by chemoautotrophs in the hypolimnion. Carbon isotopes should also provide information on processes operating in the water column and sediments, such as sulfate reduction, methanogenesis, and methanotrophy. Nitrogen isotopes should provide information about whether the organic matter was produced by nitrogen-fixing cyanobacteria or by nitrate-utilizing phytoplankton. Nitrogen isotopes should also provide information about processes operating in the complicated nitrogen cycle in the water column, including nitrification, denitrification, and ammonia volatilization.

\section{The Lakes}

Elk Lake is a deep $(30 \mathrm{~m}$ ) lake in a relatively pristine, forested setting in Itasca State Park, the headwaters area of the Mississippi River. Plant pigment analyses have been made on Holocene sediments from Elk Lake (Sanger and Hay, 1993) as have carbon-isotope analyses of the organic fraction, and carbon- and oxygen-isotope analyses and Rock-Eval pyrolysis of the bulk sediment (Dean and Stuiver, 1993). Williams and Shingobee Lakes are about $450 \mathrm{~km}$ southeast of Itasca Park in the headwaters of the Shingobee River that drains into the Mississippi. Williams is hydrologically closed with a residence time of about 3 years, whereas Shingobee is an open lake with a residence time of 6 months. Surface sediments of Williams Lake contain an average of 25 percent OC and less than 1 percent $\mathrm{CaCO}_{3}$, whereas surface sediments of Shingobee contain an average of 9 percent OC and 46 percent $\mathrm{CaCO}_{3}$ (Dean and Bradbury, 1997). Carbon and nitrogen isotopic analyses have been made of the organic fraction, and carbon and oxygen isotopic analyses have been made on bulk sediment and ostracodes (Schwalb and others, 1995; Dean and Schwalb, 2002; Schwalb and Dean, 2002).

Spectacle and Green Lakes are another hydrologically closed/open pair of lakes on the Anoka Sand Plain of eastcentral Minnesota (fig. 1). Surface sediments of Spectacle 


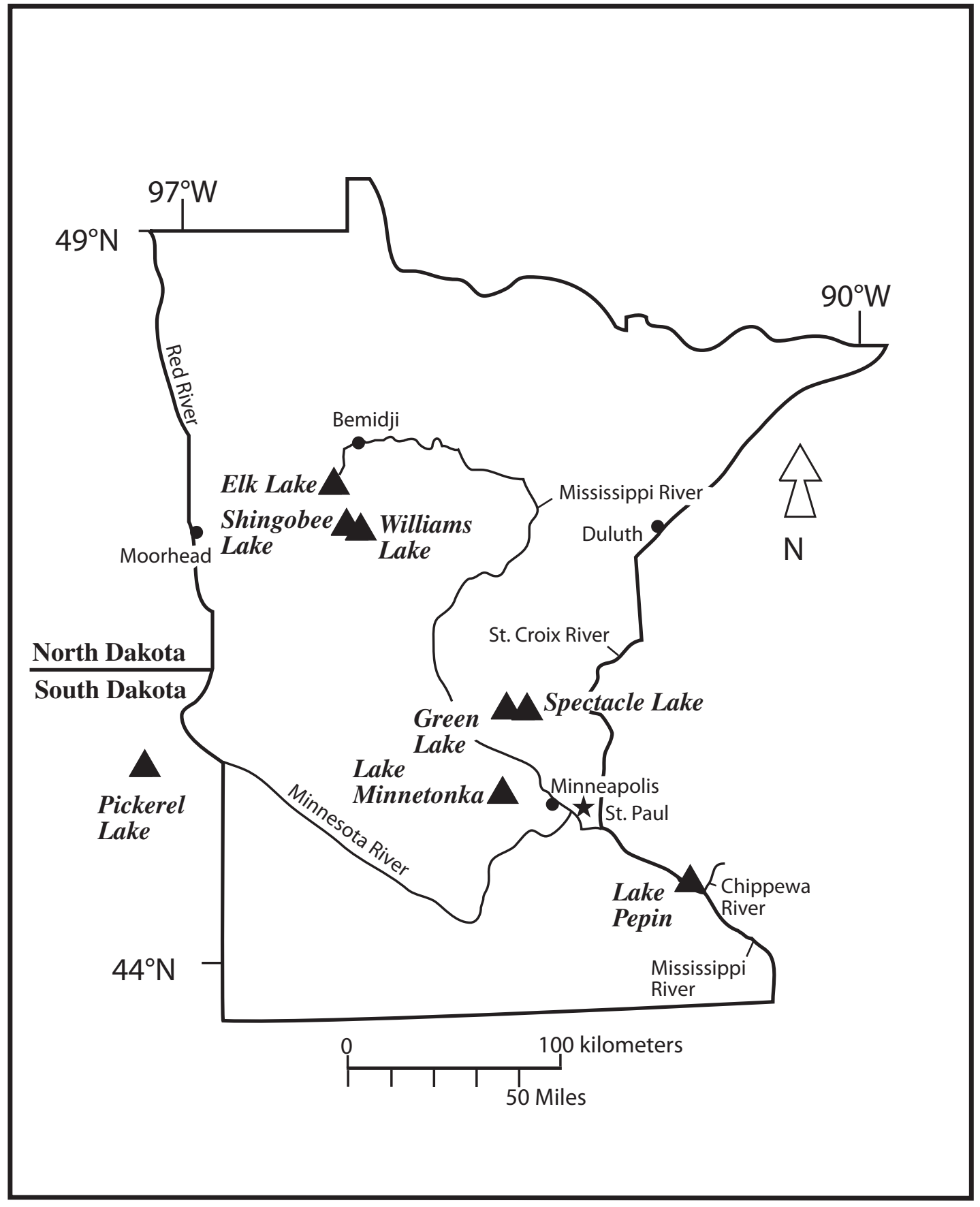

Figure 1. Map of Minnesota and adjacent North and South Dakota showing the locations of lakes discussed in this report. 


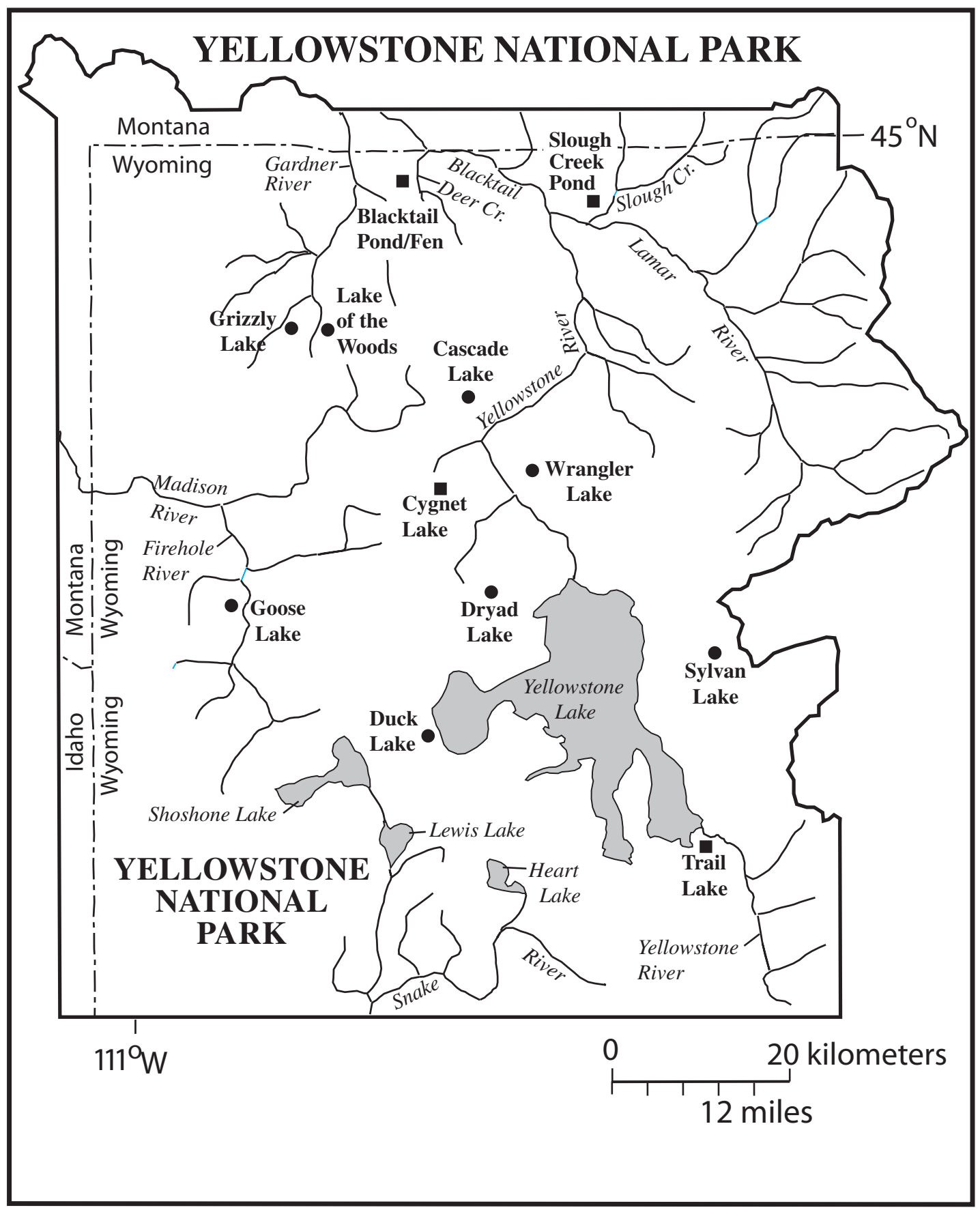

Figure 2. Map of Yellowstone National Park showing the locations of lakes discussed in this report. Lakes with cores that collected the entire Holocene records are shown as solid squares. Lakes with only short cores are shown as solid circles. 
Lake contain 21 percent $\mathrm{OC}$ and no $\mathrm{CaCO}_{3}$, whereas surface sediments of Green Lake contain 11 percent OC and 31 percent $\mathrm{CaCO}_{3}$. Lake Minnetonka is a large, many-bayed hypereutrophic lake with heavily populated shores within 13 municipalities, six of which discharge effluent from sewagetreatment plants into the lake or its tributaries (Megard, 1972). The OC contents of sediments from Minnetonka are highly variable but mostly greater than 10 percent. Lake Pepin is a natural pool formed by damming of the Mississippi River 9500 years ago by an alluvial fan at the mouth of the Chippewa River, which enters the Mississippi from Wisconsin (fig. 1; Wright and others, 1998; Brachfeld and Banerjee, 2000). The organic content of Lake Pepin sediments is low (1-3 percent OC), and should contain a higher proportion of allochthonous, terrestrial organic matter than the other six Minnesota lakes in this study. Pickerel Lake occupies one of the many depressions in calcareous drift deposited by a long tongue of the Laurentide ice sheet that extended down the Red River Valley along the Minnesota-North Dakota border. Lower Holocene sediments in Pickerel Lake are highly variable, but sediments deposited during the last 6,000 years contain a remarkable constant 40 percent $\mathrm{CaCO}_{3}$ and 4-6 percent OC. Carbon and nitrogen isotopic analyses have been made of the organic fraction, and carbon and oxygen isotopic analyses have been made on bulk sediment and ostracodes (Schwalb and Dean, 1998; Dean and Schwalb, 2000).

Trail and Sylvan Lakes are located in lodgepole pine forests with basins in the andesitic Absaroka volcanic province of eastern and southern YNP (fig. 2). Slough Creek Pond and Blacktail Pond Fen are located on Precambrian metamorphic and Tertiary volcanic bedrock, but the glacial drift contains a considerable amount of limestone and dolomite clasts, mainly derived from Paleozoic rocks in the Beartooth Mountains of southern Montana. Because of this calcareous drift, many of the lakes of northern YNP precipitate $\mathrm{CaCO}_{3}$. In addition to having calcareous sediments, Slough Creek Pond and Blacktail Pond Fen differ from the other lakes studied in YNP in that they are situated in open Douglas-fir parkland and not dense forests. The remaining eight lakes studied in YNP (fig. 2) are in dense lodgepole pine forests on the Rhyolite Plateau that covers central, western, and southern YNP (Whitlock and Millspaugh, 1996). The OC content of sediments of lakes in YNP is highly variable but is generally less than 10 percent.

\section{Materials}

Most sediment samples were obtained using a squarerod modified Livingstone piston corer (Wright, 1967). Most cores collected the entire Holocene section. Short cores (ca $4 \mathrm{~m}$ ) were obtained from Green Lake, Spectacle Lake, and the north arm of Lake Minnetonka. Pepin core D2 is one of 25 short cores taken primarily for phosphate studies (Engstrom and Almendinger 1997). The long core from Lake Pepin, collected with a Livingstone piston corer, obtained a 8,400-year sediment record of Lake Pepin (Brachfeld, and
Banerjee, 2000). Surface sediments from eight Yellowstone lakes were collected with a gravity corer to study the accumulation of ash from the 1988 Yellowstone fires (Whitlock and Millspaugh, 1996). Surface sediments from six Minnesota lakes, selected from 46 lakes reported by Dean and others (1993) as representative of a cross section of lake sediments in lakes throughout Minnesota, were collected with a Jenkins sampler.

\section{Methods}

\section{Carbon Coulometry}

Concentrations of total carbon (TC) and inorganic carbon (IC) in samples were determined by coulometric titration of $\mathrm{CO}_{2}$ following extraction from the sediment by combustion at $950^{\circ} \mathrm{C}$ and acid volatilization, respectively (Engleman and others, 1985), in USGS laboratories, Denver, Colo. Weight percent IC was converted to weight percent $\mathrm{CaCO}_{3}$ by dividing by 0.12 , the fraction of carbon in $\mathrm{CaCO}_{3}$. Organic carbon (OC) was determined by difference between TC and IC. Results of carbon analyses are listed in Appendix 1.

\section{Rock-Eval Pyrolysis}

Rock-Eval pyrolysis provides a rapid estimate of hydrogen and oxygen richness of organic matter in sediments and sedimentary rocks (Tissot and Welte, 1984; Peters, 1986). By this method, free and adsorbed hydrocarbons (HC) released by programmed heating of a sample in the Rock-Eval II instrument in flowing helium at a relatively low temperature $\left(250^{\circ} \mathrm{C}\right)$ are measured with a flame ionization detector and recorded as the area under the first peak of a pyrogram ( $\mathrm{S} 1$, in $\mathrm{mg} \mathrm{HC/g}$ sample). The second peak on a pyrogram is composed of $\mathrm{HC}$ released by thermal breakdown of kerogen or protokerogen by programmed heating of the sample to $550^{\circ} \mathrm{C}$ ( $\mathrm{S} 2$, in $\mathrm{mg} \mathrm{HC/g}$ sample). $\mathrm{CO}_{2}$ also is generated by kerogen degradation and is analyzed by a thermal conductivity detector as the third peak on a pyrogram ( $\mathrm{S} 3$, in $\mathrm{mg} \mathrm{CO}_{2} / \mathrm{g}$ sample). When normalized to the OC content, the $\mathrm{S} 2$ peak becomes the hydrogen index (HI, in $\mathrm{mg} \mathrm{HC} / \mathrm{g} \mathrm{OC}$ ), and the $\mathrm{S} 3$ peak becomes the oxygen index (OI, in $\mathrm{mg} \mathrm{CO}_{2} / \mathrm{g} \mathrm{OC}$ ).

The Rock-Eval pyrolysis technique has been used for many years as a rapid screening tool for the determination of the hydrocarbon source-rock potential of sedimentary rocks (Tissot and Welte, 1984; Peters, 1986). With careful treatment, pyrolysis can also be used to determine the hydrogen richness of "protokerogen" in modern sediments (for example Liebezeit and Wiesner, 1990; Calvert and others, 1991; Pedersen and others, 1992; Arthur and others, 1994; Dean and Gardner, 1998). Protokerogen consists largely of humic macromolecules as well as polysaccharides and proteins not yet completely degraded by heterotrophs (Whelen and Thompson-Rizer, 1993). Results of Rock-Eval pyrolysis are listed in Appendix 2. 


\section{Isotopic Analyses}

Stable carbon- and nitrogen-isotope ratios of bulk organic matter were determined by standard techniques on decalcified samples (Dean and others, 1986; Rau and others, 1987). A powdered sample was reacted with buffered acetic acid for 24 hours to dissolve carbonate minerals. The residue was then centrifuged, decanted, washed three times, and dried. The residue was then combusted at $1000^{\circ} \mathrm{C}$ with copper oxide in a sealed quartz tube. The resulting $\mathrm{CO}_{2}$ and $\mathrm{N}_{2}$ were then dehydrated and purified in a high-vacuum gas-transfer system, and the isotope ratios were determined with an isotope-ratio mass spectrometer. Results are reported in the usual per mil (\%o) $\delta$-notation relative to the Vienna Peedee belemnite (VPDB) marine-carbonate standard for carbon and air for nitrogen:

$$
\left.\delta^{13} \mathrm{C} \% \text { o (VPDB) or } \delta^{15} \mathrm{~N} \% \text { o ( } \mathrm{N} \text { air }\right)=\left[\left(\mathrm{R}_{\text {sample }} / \mathrm{R}_{\text {std }}\right)-1\right] \times 10^{3}
$$

where $\mathrm{R}$ is the ratio of ${ }^{13} \mathrm{C}$ to ${ }^{12} \mathrm{C}$ or ${ }^{15} \mathrm{~N}$ to ${ }^{14} \mathrm{~N}$, and std is the ratio in the standard (VPDB or air). Results of carbon- and nitrogen-isotope analyses are listed in Appendix 3.

\section{Results}

\section{Organic Carbon and Calcium Carbonate}

The concentrations of both $\mathrm{OC}$ and $\mathrm{CaCO}_{3}$ are highly variable both between and within lakes (fig. 3). Part of this variation is due to variation in water chemistry, which, in turn, could be due to differences in bedrock geology, surficial geology, and (or) climate, particularly the precipitation/evaporation (P/E) ratio. For example, in Minnesota there is a steep climatic gradient across the state and into the Dakotas, with net precipitation in the northeastern part of Minnesota and net evaporation in the prairies of western Minnesota and the Dakotas. Most lakes in eastern Minnesota have waters dominated by calcium and bicarbonate. As one goes west, evaporation increases, $\mathrm{CaCO}_{3}$ begins to precipitate, the bedrock and surfical geology change, and calcium and bicarbonate are replaced by magnesium, sodium, and sulfate ions (Gorham and others, 1983). As previously mentioned, the northern part of YNP is covered with calcareous glacial drift so that lakes like Blacktail Pond and Slough Creek Pond precipitate $\mathrm{CaCO}_{3}$. However, it is unlikely that the variations within the cores from Slough Creek Pond and, especially, Blacktail Pond (fig. 3B) are due to variations in the influx of $\mathrm{CaCO}_{3}$. Sediments in cores from many lakes show an inverse correlation between the concentrations of $\mathrm{CaCO}_{3}$ and $\mathrm{OC}$ as shown for Lake Minnetonka (fig. 3A) and Blacktail Pond (fig. 3B). The surface sediments from central Minnesota lakes that have measurable $\mathrm{CaCO}_{3}$ and up to 25 percent OC (Group 3 lakes of Dean and Gorham, 1976) also show this inverse relation (fig. 3A). Some lakes also show an inverse correlation in surface sediments as a function of water depth, as shown by Shingobee Lake in figure 3A (higher $\mathrm{CaCO}_{3}$ samples are from shallow water and higher
OC samples are from deeper water). I attribute this inverse correlation as due mostly to dissolution of $\mathrm{CaCO}_{3}$ by the "carbon pump."

By carbon pump, I refer to the lacustrine carbon pump as described by Dean (1999) in which carbon is fixed by photosynthesis in the epilimnion, thus removing $\mathrm{CO}_{2}$, increasing the $\mathrm{pH}$, and increasing the dissolved $\mathrm{O}_{2}$. Respiration of this fixed organic carbon $(\mathrm{OC})$ in the hypolimnion consumes $\mathrm{O}_{2}$, produces $\mathrm{CO}_{2}$, and lowers the $\mathrm{pH}$. This carbon pump also recycles phosphorus $(\mathrm{P})$ and, if the carbon-fixing organisms are diatoms, silica ( $\mathrm{Si}$ ). In hardwater lakes, the increased $\mathrm{pH}$ in the epilimnion can trigger precipitation of $\mathrm{CaCO}_{3}$. However, the lower $\mathrm{pH}$ of the hypolimnion can result in the dissolution of much of the $\mathrm{CaCO}_{3}$ produced in the epilimnion. More $\mathrm{CaCO}_{3}$ is dissolved at the sediment/water interface before it is buried, and even more is dissolved in corrosive pore waters. Williams Lake does precipitate $\mathrm{CaCO}_{3}$ during the summer (McConnaughey and others, 1994), but the surface sediments are virtually carbonate-free (fig. 3A). Adsorbed coatings of dissolved organic compounds can reduce rates of $\mathrm{CaCO}_{3}$ dissolution (Hoch and others, 1999; Wetzel, 2001). If oxygen depletion in the hypolimnion is severe enough to produce seasonal anoxia, there is a profound effect on the cycles of redox-sensitive elements such as iron $(\mathrm{Fe})$ and manganese $(\mathrm{Mn})$, causing the concentration of the dissolved forms $\left(\mathrm{Fe}^{+2}\right.$ and $\left.\mathrm{Mn}^{+2}\right)$ to increase in the hypolimnion (Dean and others, 2003). The carbonate and, especially, the redox aspects of the carbon pump have been summarized in detail by Wetzel (2001), although he did not call it that.

Increased OC content of lake sediments often accompanies eutrophication following land clearing and other activities by European settlers (about A.D. 1850 in Minnesota), and this usually is accompanied by decreased $\mathrm{CaCO}_{3}$ content. For example, the average $\mathrm{OC}$ and $\mathrm{CaCO}_{3}$ contents of presettlement Holocene sediments in Shingobee Lake are 2.5 percent and 70 percent (fig. 3A); the average contents in surface sediments from Shingobee Lake are 8.8 percent and 46 percent, although both values have a considerable range (diagonal blue line in figure $3 \mathrm{~A}$ ). The change in Green Lake sediments is even more striking. Sediments at $150 \mathrm{~cm}$ (about A.D. 1850) in a core from Green Lake contain about 80 percent $\mathrm{CaCO}_{3}$ and 6 percent OC. However, sediments at 20 -cm depth only contain 32 percent $\mathrm{CaCO}_{3}$ but almost 15 percent $\mathrm{OC}$ (fig. 3A). Sediments in the northern YNP lakes, especially Blacktail Pond, show the same inverse trend but with more scatter (fig. 3B). Although the lacustrine carbon pump probably does not operate universally in all lakes, it appears that burial of a large amount of OC can increase dissolution of $\mathrm{CaCO}_{3}$. The amount of $\mathrm{CaCO}_{3}$ that accumulates on the lake floor, and ultimately is buried in the sediments, is a function of how much is produced in the epilimnion and how much is destroyed in the hypolimnion and sediments.

\section{Rock-Eval Pyrolysis}

An OI-HI cross plot, a proxy for a van Krevelen-type $\mathrm{O} / \mathrm{C}-\mathrm{H} / \mathrm{C}$ diagram (Tissot and Welte, 1984), is the conventional 

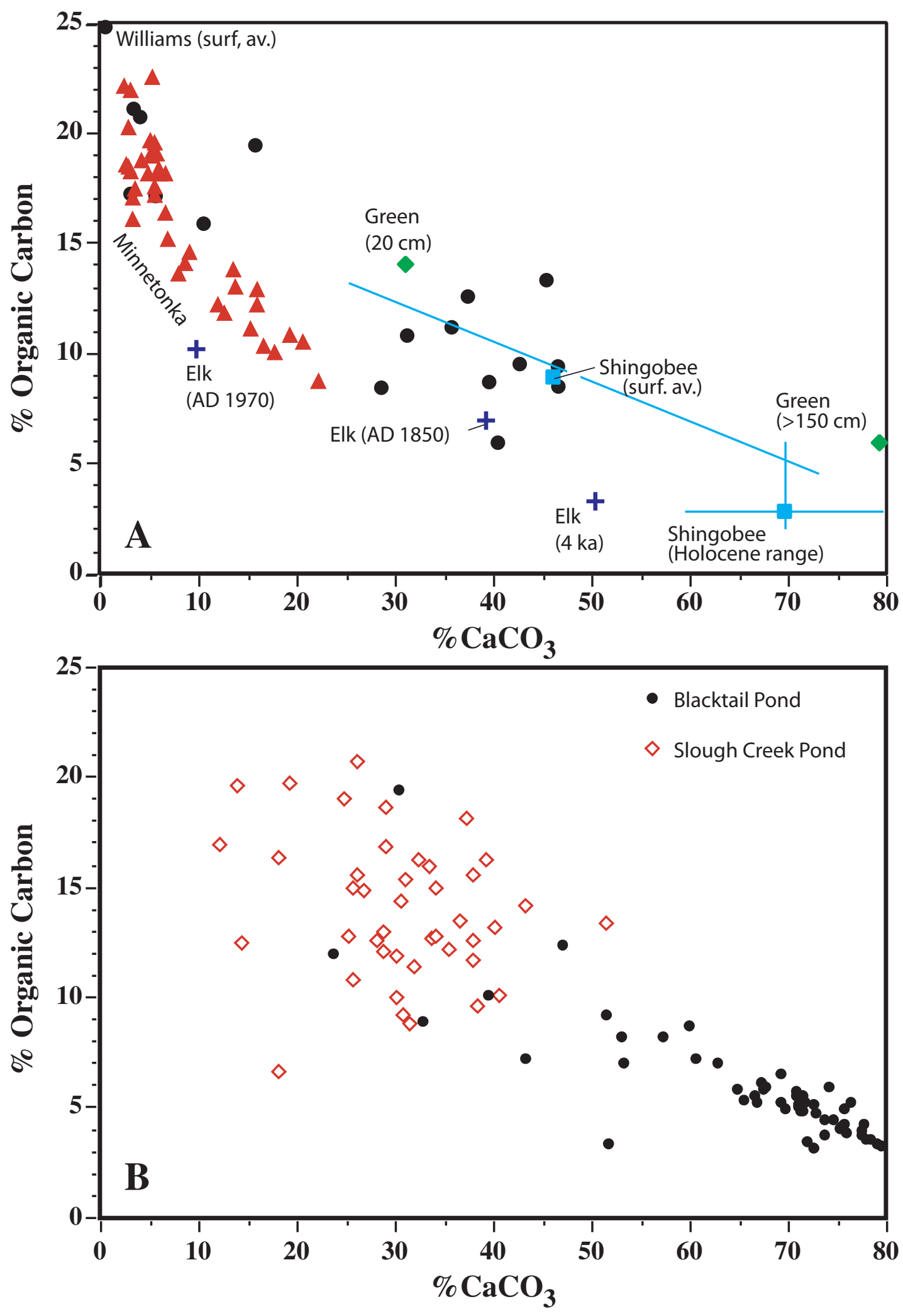
Figure 3. (previous page) Cross plot of percentage of $\mathrm{CaCO}_{3}$ versus percentage of $\mathrm{OC}$ in: $(A)$ Surface sediments from central Minnesota lakes and in a core from Lake Minnetonka. Solid circles are surface sediments from central Minnesota lakes that contain both $\mathrm{CaCO}_{3}$ and $\mathrm{OC}$ (Group 3 sediments of Dean and Gorham, 1976). Red triangles are sediments from Lake Minnetonka. Horizontal and vertical lines labeled "Shingobee (Holocene range)" represent the ranges of concentrations of $\mathrm{CaCO}_{3}$ and $\mathrm{OC}$ measured in Holocene sediments in Shingobee Lake. The square symbol at the intersection of the horizontal and vertical lines represents the average concentrations of $\mathrm{CaCO}_{3}$ and $\mathrm{OC}$ in Holocene sediments in Shingobee Lake. The diagonal line is the best fit line $(r=0.92 ; n=6)$ for the range of concentrations of $\mathrm{CaCO}_{3}$ and $\mathrm{OC}$ measured in surface sediments in Shingobee Lake (Dean and Bradbury, 1997), and the square symbol labeled "Shingobee (surf. av.)" is the average of the surface-sediment measurements. The symbol labeled "Green $(20 \mathrm{~cm})$ " is the composition of Green Lake sediments at 20 centimeter $(\mathrm{cm})$ depth, and the point labeled "Green (greater than $150 \mathrm{~cm}$ )" is the average composition of Green Lake sediments deeper than $150 \mathrm{~cm}$. The points labeled "Elk (4 ka)," "Elk (AD 1850)," and "Elk (AD 1970)" are the compositions of sediments from the deepest part of Elk Lake deposited about 4,000 years ago, 155 years ago, and 35 years ago, respectively. $(B)$ Cores from Blacktail Pond and Slough Creek Pond in northern Yellowstone Park.

way of displaying results of Rock-Eval pyrolysis and defining types of kerogen in hydrocarbon source rocks. An OI-HI plot for samples from Spectacle Lake, Lake Pepin, Elk Lake, and Lake Minntonka in Minnesota, and for samples of surface sediments from 18 Minnesota lakes is shown in figure 4. An OI-HI plot for samples from Trail Lake and Slough Creek Pond in YNP is shown in figure 5. Three types of kerogen (I, II, and III) and their thermal maturation pathways are shown by the curves on the OI-HI plots. Type I kerogen consists of extremely lipidrich, sapropelic, algal organic compounds typified by lacustrine oil shale of the Eocene Green River Formation (Tissot and Welte, 1984). Type III kerogen is the other extreme and consists of H-poor organic compounds, such as those found in terrestrial organic matter. Type II kerogen also consists of H-rich compounds such as those found in autochthonous lacustrine and marine organic matter. Marine hydrocarbon source rocks typically contain type II kerogen. Type III kerogen also may be formed by oxidation of type II kerogen, which lowers the HI and increases the OI (Tissot and Welte, 1984).

The extreme range of HI values shown for the data from Trail Lake and Slough Creek Pond (fig. 5) could result from a mixture of autochthonous and terrestrial organic matter or, more likely, from variable oxidation of algal organic matter in the depositional environment. Trends in the data for the Minnesota lakes (fig. 4) with negative slopes, going from high HI, low OI, to lower $\mathrm{HI}$ and much higher OI are likely oxidation trends. The samples from Lake Pepin on the Mississippi River contain mostly type III terrestrial organic matter. The samples from Spectacle Lake contain unoxidized algal type I organic matter. The samples from hypereutrophic Lake Minnetonka also contain type I organic matter, but the organic matter in this urban lake has been variously oxidized. Most other Minnesota lakes fall in the range of type II organic matter but with HI values less than 400. The plant-pigment data of Sanger and Gorham (1970) and Gorham and Sanger (1975) indicate that the organic matter in most Minnesota Lakes is predominantly autochthonous. The three lakes from northeastern Minnesota, judged by plant pigments to contain significant allocthonous organic matter, plot in the middle for the field of Minnesota surface sediments in figure
4. Therefore, I conclude that the low HI values in Minnesota surface sediments are due to oxidation of autochthonous organic matter that originally had higher HI values, and, for three lakes, are due to significant influx of allocthonous organic matter. Elk Lake today is seasonally anoxic below $10 \mathrm{~m}$ (July-October; Megard and others, 1993) and may have been anoxic in the past (Dean, 1993). Plant-pigment data (Sanger and Hay, 1993) indicate that the lake evolved from oligo- to mesotrophic conditions in its early history to meso- to eutrophic conditions over the last 3,000 years, and at no time was there large-scale influx of allocthonous organic matter. The entire Holocene sediment record in Elk Lake is laminated (varved), and, therefore, I would expect the autochthonous organic matter in these sediments to be well preserved. However, the Lake is deep $(30 \mathrm{~m})$ and the low HI values may be due to oxidation of organic matter on its long trip through the water column.

Because the $\mathrm{HI}$ is derived from $\mathrm{S} 2$ by normalizing to percentage of $\mathrm{OC}(\mathrm{HI}=[\mathrm{S} 2 / \% \mathrm{OC}] \times 100)]$,Langford and Blanc-Valleron (1990) suggested that the average value for $\mathrm{HI}$ for a particular data set could be obtained from the slope of a regression equation for a graph of \%OC versus S2 (fig. 6). In the examples from Lake Pepin, Lake Minnetonka, Spectacle Lake, and Elk Lake in Minnesota and Slough Creek Pond and Trail Lake in YNP, the slopes of the regression equations are 2.73, 11.6, 10.6, 2.03, 6.07, and 6.49, respectively (fig. 6). Multiplying these slope coefficients by 100 (Langford and Blanc-Valleron, 1990) yields average values of HI of 273, 1160, 1060, 203, 607, and 649, respectively. Langford and Blanc-Valleron (1990) further suggested that lines with zero intercept and slopes of $7(\mathrm{HI}=700)$ and 2 $(\mathrm{HI}=200)$ separate the pyrolitic hydrocarbon yields of type I and type II, and type II and type III kerogen, respectively (dashed lines in figure 6). Figure 6 shows that the samples from Lake Pepin with values of S2 less than 10 are the most $\mathrm{H}$-depleted. Likewise samples from Spectacle Lake with values of S2 greater than 200 are the most $\mathrm{H}$-enriched. The samples from Lake Minnetonka and Elk Lake and from the two YNP lakes are of intermediate $\mathrm{H}$ richness, with values of S2 mostly between 10 and 200 . 


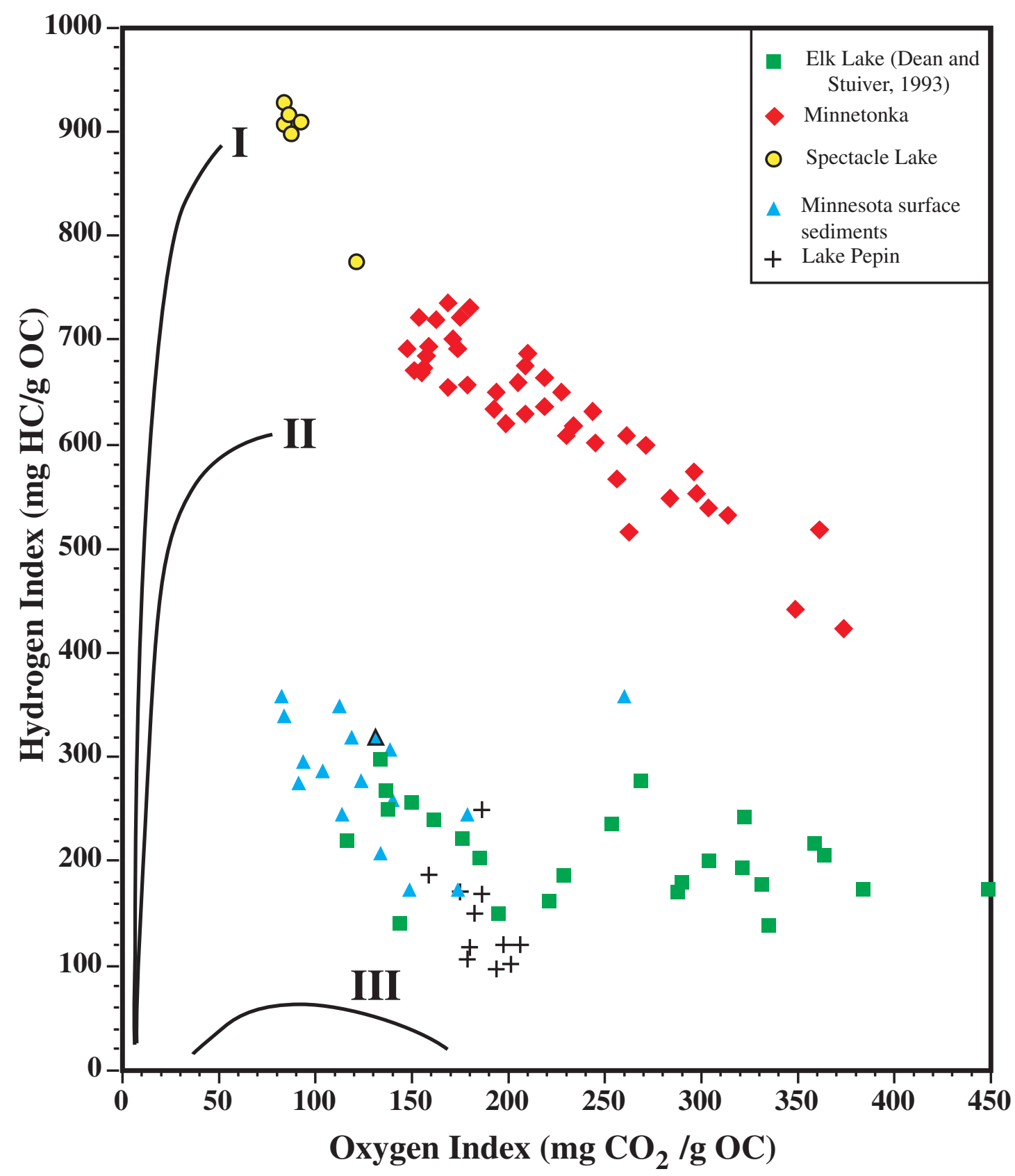

Figure 4. A cross plot of Rock-Eval pyrolysis oxygen index versus hydrogen index for samples of selected Minnesota lake sediments. Curves labeled I, II, and III describe the thermal maturation pathways of type I, type II, and type III kerogen. 


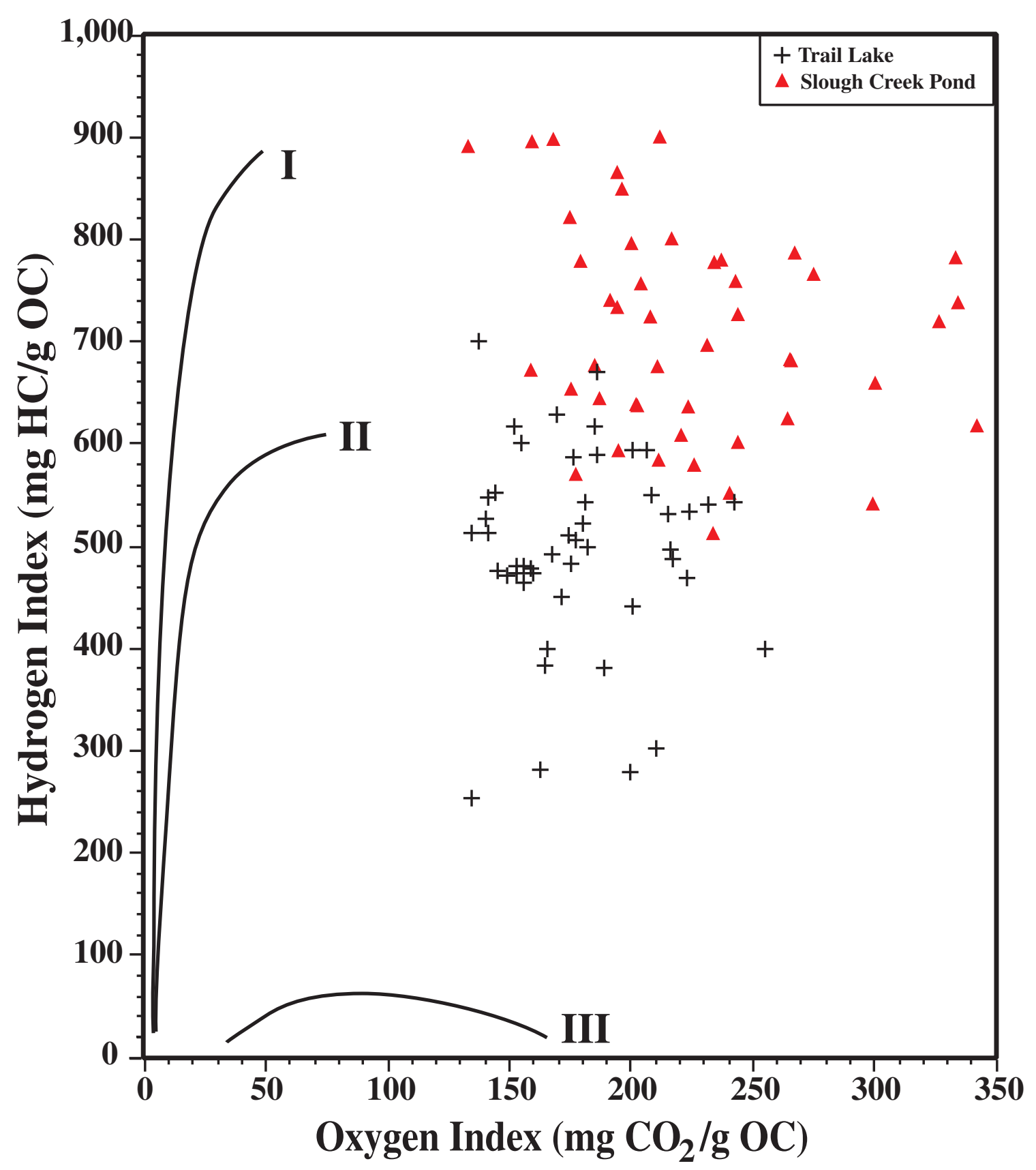

Figure 5. A cross plot of Rock-Eval pyrolysis oxygen index versus hydrogen index for samples of sediments from Trail Lake and Slough Creek Pond in Yellowstone National Park. Curves labeled I, II, and III describe the thermal maturation pathways of type I, type II, and type III kerogen. 

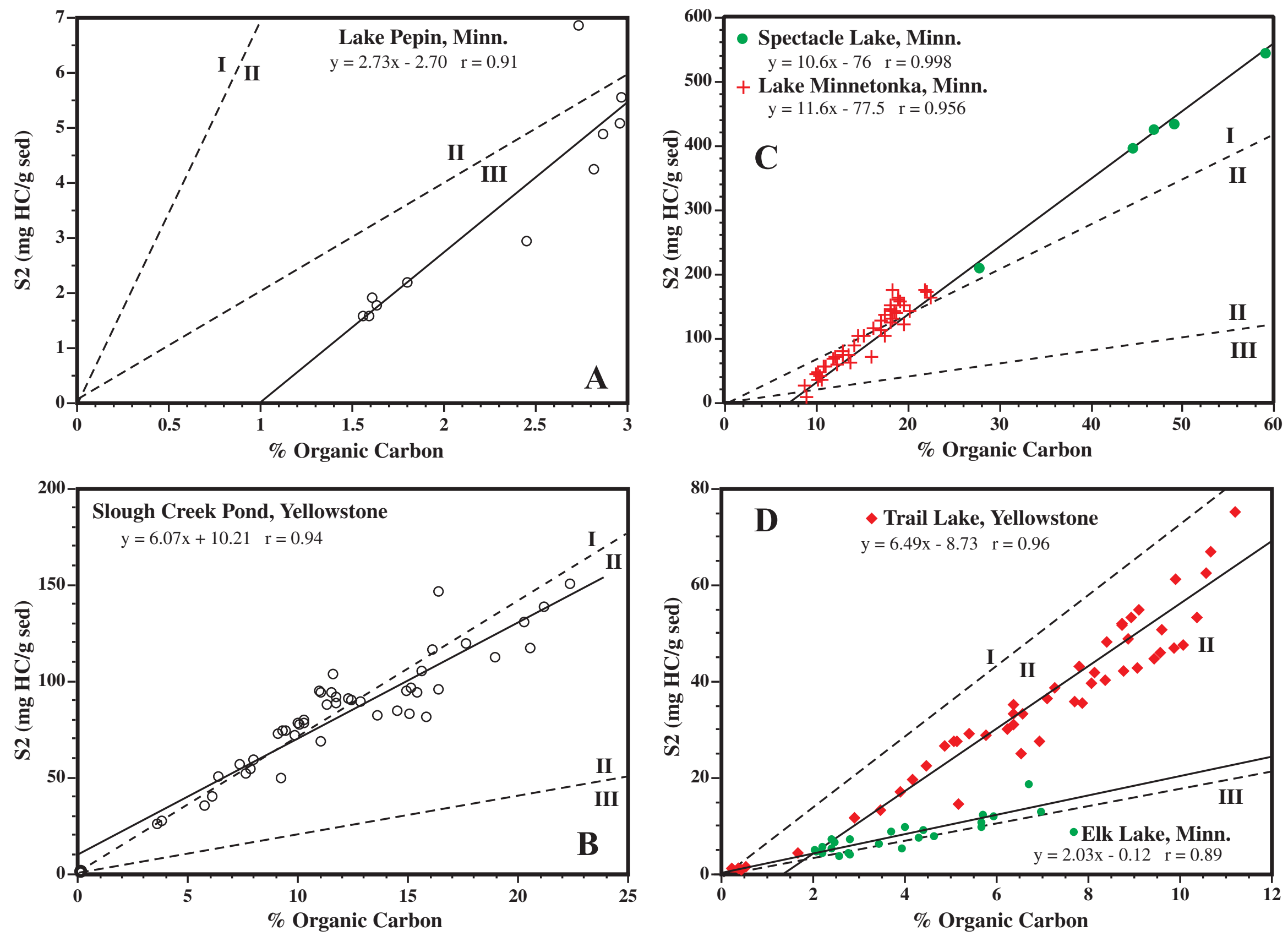

Figure 6. Cross plots of percentage of OC versus Rock-Eval pyrolysis S2 peak height in milligrams of hydrocarbons (HC) per gram of OC for samples of lake sediments from $(A)$ Lake Pepin in Minnesota; $(B)$ Slough Creek Pond, Yellowstone National Park; $(C)$ Spectacle Lake and Lake Minnetonka in Minnesota; $(D)$ Elk Lake in Minnesota and Trail Lake in Yellowstone National Park. 


\section{Carbon and Nitrogen Isotopes}

The potential of values of $\delta^{13} \mathrm{C}$ and $\delta^{15} \mathrm{~N}$ in organic matter in lake sediments as source signatures can be seen in figs. 6 and 7, which show values of $\delta^{13} \mathrm{C}$ and $\delta^{15} \mathrm{~N}$ in lake sediments from Minnesota and Yellowstone, and in different types of plants $\left(\delta^{13} \mathrm{C}\right)$ and in different forms of nitrogen in the nitrogen cycle $\left(\delta^{15} \mathrm{~N}\right)$. Most higher plants follow the $\mathrm{C} 3$ photosynthetic pathway and produce organic carbon that is depleted in ${ }^{13} \mathrm{C}$ (more negative values of $\delta^{13} \mathrm{C}$ ). Usually, most $\mathrm{C} 3$ terrestrial vegetation tends to have values of $\delta^{13} \mathrm{C}$ around -26 to $-28 \%$ o. Unfortunately, lake plankton also tend to fractionate isotopes of carbon in the same range as C3 higher plants with values of $\delta^{13} \mathrm{C}$ usually in the high negative 20s to low negative 30s (Oana and Deevey, 1960; Deines, 1980; fig. 7). C4 plants, such as warm prairie grasses, fix carbon that is significantly enriched in ${ }^{13} \mathrm{C}$ (less negative values of $\delta^{13} \mathrm{C}$; O'Leary, 1988; Cerling and Quade, 1993).

\section{$\delta^{13}$ Corg (VPDB)}

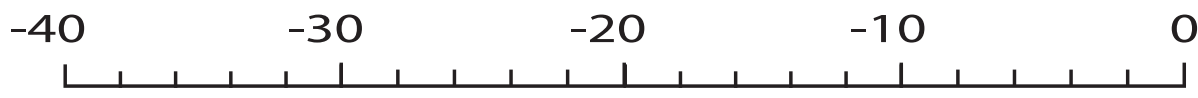

C3 plants _ _ C4 plants

peat

lake plankton

(Dean and Stuiver, 1993)

(Dean and Anders, 1991;

Collister and Hayes, 1991)

algal oxidized

surf. seds., Minnesota lakes

Green River Oil Shale

(Hollander and others, _Lake Greifen (Switzerland)

1992)

Holocene early mid Elk Lake (Dean and Stuiver, 1993)

and late

Lake Minnetonka (late Holocene)

Green Lake (late Holocene) - - - Spectacle Lake (late Holocene)

$($ Holocene; core 97-P1)
$(1992 ;$ core D2) + Lake Pepin

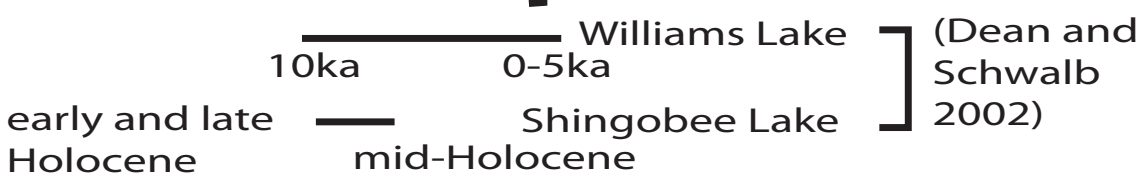

Pickerel Lake

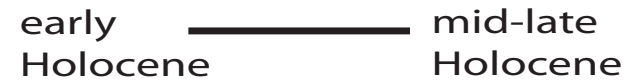

(Dean and Schwalb, 2000)

surface seds., YNP

Holocene Trail Lake, YNP

Holocene Blacktail Pond Fen, YNP

Holocene $\quad$ Slough Creek Pond, YNP

Holocene Cygnet Lake, YNP

Figure 7. Ranges of values of $\delta^{13} \mathrm{C}$ in various plant materials and in organic matter in lake sediments. Data for lake plankton, C3 plants, C4 plants, and peat were compiled by Bender (1971) and Deines (1980). YNP, Yellowstone National Park. 


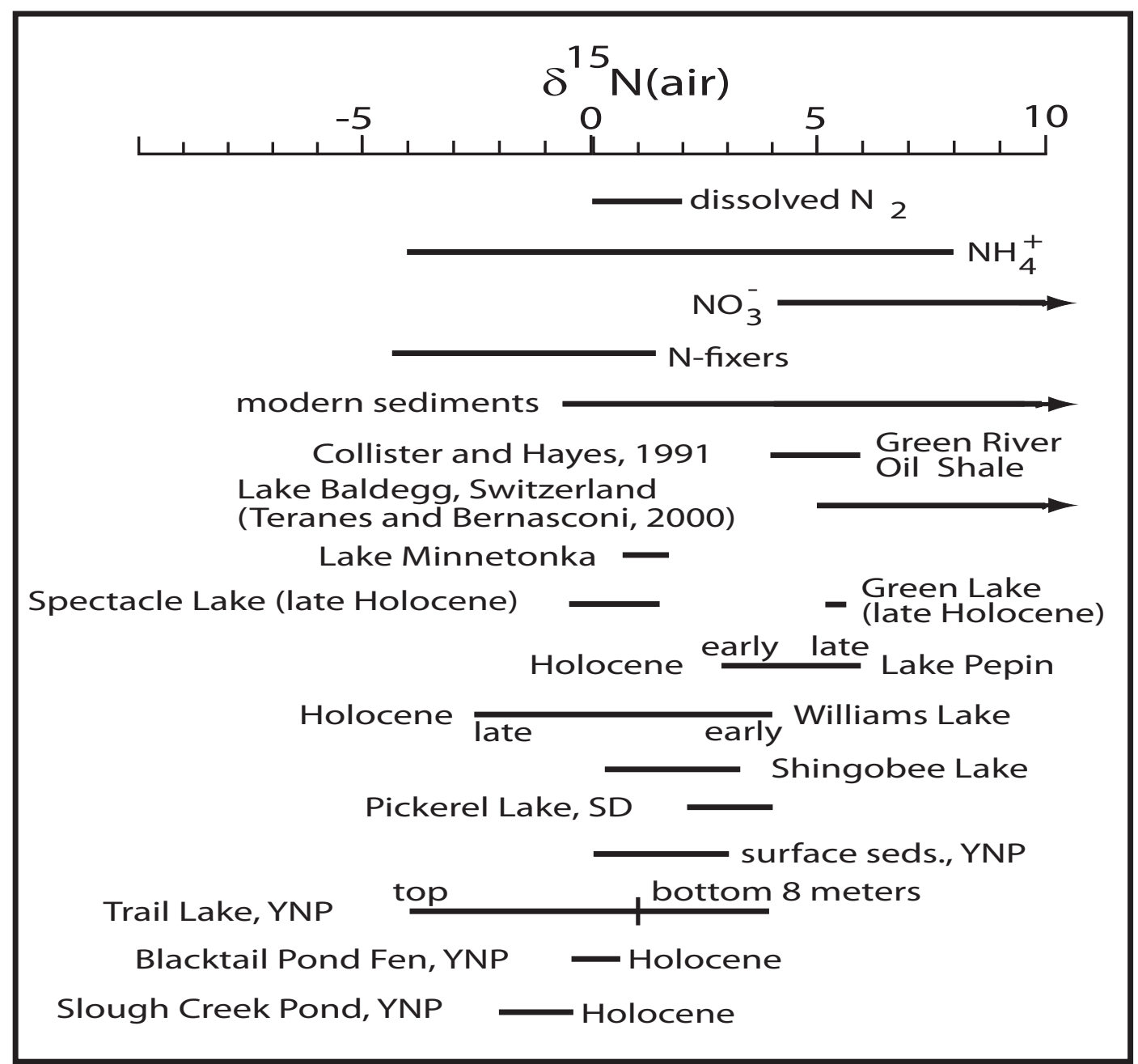

Figure 8. Ranges of values of $\delta^{15} \mathrm{~N}$ in various nitrogen-bearing pools (from Rau and others, 1987), and in organic matter in lake sediments. SD, South Dakota; YNP, Yellowstone National Park.

These observations assume that photosynthesis is the primary control on the isotopic signature in an aquatic carbon cycle. However, in more productive aquatic systems, anoxic conditions in the water column or in the sediments may create conditions favorable for microbially mediated processes such as sulfate reduction, chemoautotrophy, methanogenesis, and methanotropy, which can produce distinct isotopic signatures to sedimentary carbon that may be more ${ }^{13} \mathrm{C}$-depleted or more ${ }^{13} \mathrm{C}$-enriched than carbon produced by photosynthetic processes (Hollander and Smith, 2001). Hydrologic conditions, such as increased residence time and ground-water interactions, also can alter carbon-isotope signatures.

For the Yellowstone lakes, the carbon isotope results generally support the Rock-Eval pyrolysis results: Trail
Lake, which had the least H-rich organic matter, has values of $\delta^{13} \mathrm{C}$ ranging from $-25 \%$ to $-29 \%$, and Slough Creek Pond, which had the most H-rich (most algal) organic matter, has $\delta^{13} \mathrm{C}$ values in the range of $-29 \%$ o to $-31 \%$, more similar to values in lake plankton and the most algal rich of Minnesota surface sediments (fig. 7). Samples from Blacktail Pond Fen have values of $\delta^{13} \mathrm{C}$ that span almost the entire range of values in both Slough Creek Pond and Trail Lake, whereas samples from Cygnet Lake are considerably more enriched $i{ }^{13} \mathrm{C}$ than those from the other Yellowstone lakes. Surface sediments from eight lakes have $\delta^{13} \mathrm{C}$ values in a narrow range of $-27 \%$ o to $-30 \%$, suggesting that the organic matter is either algal or derived from C3 forest plants. 
The samples from Minnesota Lakes give a somewhat confusing signal if simple photosynthetic isotopic fractionation is assumed. Samples of surface sediments from lakes thoughout Minnesota (Dean and Stuiver, 1993) have values of $\delta^{13} \mathrm{C}$ that range from -22 to $-32 \%$. Those sediments, based on fossil pigments (Sanger and Gorham, 1970; Gorham and Sanger, 1975), that contain the most algal organic matter are most depleted in ${ }^{13} \mathrm{C}$, and sediments with the most oxidized organic matter are most enriched in ${ }^{13} \mathrm{C}$ (fig. 7). These results are to be expected because samples most depleted in ${ }^{13} \mathrm{C}$ (values of $\delta^{13} \mathrm{C}$ in the high negative 20s and low negative 30s) are the most H-rich, that is, the organic matter is isotopically more like lake plankton and less like peat (fig. 7). However, samples from Lake Minnetonka and Spectacle Lake that are $\mathrm{H}$-rich (fig. 4) have higher values of $\delta^{13} \mathrm{C}$ than those from Lake Pepin that are H-poor (figs. 4 and 7), which is difficult to explain by photosynthetic fractionation. Values of $\delta^{13} \mathrm{C}$ in samples from Elk Lake, Williams Lake, Shingobee Lake, and Pickerel Lake are lowest in early Holocene sediments and highest in mid-Holocene sediments (fig. 7). In cores from Elk Lake and Shingobee Lake, values of $\delta^{13} \mathrm{C}$ return to ${ }^{13} \mathrm{C}$-depleted early Holocene levels in late Holocene sediments but remain unchanged in cores from Williams Lake and Pickerel Lake (fig. 7).

Most processes involved in the nitrogen cycle tend to drive values of $\delta^{15} \mathrm{~N}$ toward more positive values relative to $\mathrm{N}_{2}$ in air, which, by definition, has a value of 0 (fig. 8). Methanogenic and nitrogen-fixing organisms can produce negative values of $\delta^{15} \mathrm{~N}$, but most processes operating in the nitrogen cycle tend to produce nitrogen that is more enriched in ${ }^{15} \mathrm{~N}$. It is noteworthy that sediments from Lake Pepin, the wide spot in the Mississippi River in Minnesota with the least algal, $\mathrm{H}$ rich organic matter, have the highest values of $\delta^{15} \mathrm{~N}$, as do the late Holocene sediments from Green Lake (fig. 8). Those sediments with the most H-rich organic matter (for example, Lake Minnetonka and Spectacle Lake in Minnesota and all of the Yellowstone lakes) have $\delta^{15} \mathrm{~N}$ values around 0 (fig. 8). The low values in algal-rich sediments suggest that $\mathrm{N}$-fixing bacteria (cyanobacteria) may represent a significant proportion of the primary producers in those lakes.

\section{Discussion}

The organic carbon and S2 data plotted in figure 6 show that the two variables are highly correlated, which indicates that most of the organic matter in these sediments is lipid-rich, algal organic matter. Using both the $\mathrm{HI}$ and the S2 peak as measures of H-richness (figs. 4, 5, and 6), the sediments from Spectacle Lake and Lake Minnetonka in Minnesota (figs. 4 and 6C) and Slough Creek Pond in YNP (figs. 5 and 6B) are the most H-rich; sediments from Lake Pepin in Minnesota (figs. 4 and 6A) are the least H-rich, and sediments from Elk Lake in Minnesota and Trail Lake in YNP (fig. 6D) are intermediate in $\mathrm{H}$ richness.
Based on these H-richness measurements, and the ${ }^{13} \mathrm{C}$-depleted isotopic signature of type I kerogen from lacustrine Green River oil shale (fig. 7), the sediments in Minnetonka and Spectacle should be much more depleted in ${ }^{13} \mathrm{C}$ with values of $\delta^{13} \mathrm{C}$ of about $-30 \%$ to $-32 \%$,. Spectacle Lake is hydrologically closed with a longer residence time than nearby Green Lake, which is hydrologically open and has a much shorter residence time. The longer residence time of Spectacle Lake might explain the ${ }^{13} \mathrm{C}$-enriched signature of organic matter in the sediments of that lake as ${ }^{13} \mathrm{C}$-depleted carbon is fixed by $\mathrm{H}$-rich plankton causing the entire carbon reservoir to be enriched in ${ }^{13} \mathrm{C}$ (McKenzie, 1985; Hollander and McKenzie, 1991).

Williams Lake and Shingobee Lake are another hydrologically closed/open pair of lakes in the headwaters area of the Shingobee River in northwestern Minnesota (fig. 1). Williams Lake apparently was hydrologically open in the early Holocene, with geochemical and isotopic characteristics of sediments similar to those in Shingobee Lake when the two lakes were connected as part of a larger lake, "Lake Willobee" formed by a debris flow across the Shingobee River (Dean and Schwalb, 2002; Schwalb and Dean, 2002). After the debris flow was breached, Williams Lake had no surface inflow and evolved into a closed lake by about $5 \mathrm{ka}$. This hydrologic closure is documented by the ca. $10 \%$ increase in $\delta^{13} \mathrm{C}$ (from ca $-34 \%$ o to $-24 \%$; fig. 7). Over the same time period (10-5 ka), the vegetation in the drainage basins of these lakes evolved from coniferous forest to prairie (the so-called "prairie period" in Minnesota; Whitlock and others, 1993; Locke, 1995; Schwalb and others, 1995), synchronous with the eastward expansion of prairie and oak savanna that is well documented for the north-central United States (Webb and others, 1983; Whitlock and others, 1993; Baker and others, 1998). The ca. $3 \%$ increase in $\delta^{13} \mathrm{C}$ in sediments of Shingobee Lake has been attributed to a change in dominant vegetation from forest to prairie, and $3 \%$ of the $10 \%$ increase in $\delta^{13} \mathrm{C}$ in Williams Lake (fig. 7) also has been attributed to vegetation change (Dean and Schwalb, 2002; Schwalb and Dean, 2002. After the forests returned to northwestern Minnesota, values of $\delta^{13} \mathrm{C}$ in Shingobee Lake (fig. 7; Dean and Schwalb, 2002) returned to early Holocene lower values of $\delta^{13} \mathrm{C}$ (ca. $-33 \%$; fig. 7). The sediments of Williams Lake remained enriched in ${ }^{13} \mathrm{C}\left(\delta^{13} \mathrm{C}-24 \%\right.$ o to $-26 \%$; fig. 7$)$ because the lake remained hydrologically closed.

A shift to higher values of $\delta^{13} \mathrm{C}$ during the mid-Holocene also was found in sediments from Elk Lake, northwestern Minnesota (Dean and Stuiver, 1993; Dean and others, 2002), and in sediments from Pickerel Lake in northeastern South Dakota (fig. 7; Dean and Schwalb, 2000). Sediments deposited in Elk Lake during the prairie period have an OC accumulation rate more than twice that for sediments deposited prior to the prairie period (Dean, 1993), higher plant pigment concentrations (Sanger and Hay, 1993), and a higher total flux of diatoms (Bradbury and Dieterich-Rurup, 1993). These different lines of evidence all suggest that productivity of Elk Lake was higher during the prairie period. The increase in 
values of $\delta^{13} \mathrm{C}$ of both organic and inorganic carbon during the prairie period was the result of increased burial of ${ }^{13} \mathrm{C}$-depleted organic matter making the entire carbon reservoir of the lake ${ }^{13} \mathrm{C}$-enriched according to the model of McKenzie (1985) (Dean and Stuiver, 1993). Values of $\delta^{13} \mathrm{C}$ in late Holocene sediments of Elk Lake decreased as lake productivity decreased. There are distinct covariant increases in values of $\delta^{18} \mathrm{O}$ and $\delta^{13} \mathrm{C}$ in carbonate in the early Holocene in Pickerel Lake, which suggests that there was an increase in water-residence time (Dean and Schwalb, 2000). However, these trends are paralleled by an upward trend in values of $\delta^{13} \mathrm{C}$ in OC (from $-30 \%$ o to $-24 \%$; fig. 7 ). This suggests that the change from forest to prairie conditions may have had an even greater influence than water-residence time by providing more ${ }^{13} \mathrm{C}$ to soils and hence to the dissolved inorganic carbon (DIC) reservoir in the lake. Both factors could have produced more ${ }^{13} \mathrm{C}$-enriched carbon values in precipitated carbonate in Pickerel Lake.

So far, this discussion has only considered photoautotrophic production of organic matter. During the spring-summer growing season in a lake, ${ }^{13} \mathrm{C}$-depleted $\mathrm{CO}_{2}$ is continually being removed from the photic zone and fixed in ${ }^{13} \mathrm{C}$-depleted organic matter, which is sedimented. The $\mathrm{CO}_{2}$ reservoir in the epilimnion by the end of the growing season will be enriched in ${ }^{13} \mathrm{C}$ relative to that at the beginning of the growing season so that any carbon fixed in organic matter at the end of the season will be similarly enriched in ${ }^{13} \mathrm{C}$ (Hollander and Smith, 2001). If the particulate organic carbon (POC) that ultimately accumulates in the sediments is more ${ }^{13} \mathrm{C}$-depleted than POC produced during the summer in the epilimnion, then there must be another source of ${ }^{13} \mathrm{C}$-depleted POC. Likely candidates for production of this ${ }^{13} \mathrm{C}$-depleted POC are chemoautotrophic or methanotrophic bacteria in the hypolimnion (Hollander and Smith, 2001). Lake sediments with high OC contents commonly are anoxic for extended periods of time during the year, which can result in extensive methanogenesis and release of ${ }^{13} \mathrm{C}$-depleted methane (values of $\delta^{13} \mathrm{C}$ typically about $-50 \%$ o to $-70 \%$ ) to the hypolimnion (Striegl and Michmerhuizen, 1997). Methanotrophic bacteria can further fractionate the carbon-isotopic signature of the methane they utilize by up to $30 \%$ (Summons and others, 1994). By this combination of ${ }^{13} \mathrm{C}$-depleting processes (methanogenesis and methanotrophy), the POC produced by methanotrophy can be depleted by as much as $-90 \%$ (Whiticar and others, 1986). In the recently deposited sediments of eutrophic Lake Mendota in Wisconsin, values of $\delta^{13} \mathrm{C}$ in organic matter in summer varves are $2-3 \%$ o lower than POC produced in the epilimnion during the summer because of the addition of ${ }^{13} \mathrm{C}$-depleted POC produced by methanotrophic bacteria in the hypolimnion (Hollander and Smith, 2001). Thus, in moderately eutrophic lakes, such as modern Lake Mendota and pre-1930 Lake Greifen in Switzerland (Hollander and others, 1992; Hollander and Smith, 2001) production of ${ }^{13} \mathrm{C}$-enriched phytoplankton POC that accumulates in the sediments is insufficient to overprint the highly ${ }^{13} \mathrm{C}$-depleted POC produced by chemoautotrophic and methanotrophic process in the hypolimnion. In hypereutrophic lakes, such as modern Lake Greifen, epilimnetic production of ${ }^{13} \mathrm{C}$-enriched phytoplankton during the summer can be so intense that this POC overwhelms any ${ }^{13} \mathrm{C}$-depleted POC produced by bacteria in the hypolimnion (Hollander and Smith, 2001).

Applying these principles to the lakes discussed previously, provides some insight into the extreme variability in values of $\delta^{13} \mathrm{C}$. The lakes of southern YNP contain low concentrations of sulfate ( $\mathrm{SO}_{4}$; National Park Service, 1994) and are not likely to have very much sulfate reduction occurring in their sediments or hypolimnions, but may have some methanogenesis. Hence the relatively high values of $\delta^{13} \mathrm{C}$ in sediments in Trail Lake and Cygnet Lake ( $-25 \%$ o to $-30 \%$; fig. 6) are mostly from POC produced by phytoplankton during late summer in the epilimnion. Values of $\delta^{13} \mathrm{C}$ in sediments from Trail Lake range between -24 and $-28 \%$ and have no trend with values of HI (fig. A), which would be expected if the organic matter was a mixture of terrestrial and algal POC. The OC-S2 plot for Trail Lake (fig. 6D) indicates that the sediments in Trail Lake contain type II organic matter, but close to the I-II line. Also, values of $\delta^{13} \mathrm{C}$ fall within a fairly narrow range (fig. 9A). Therefore, the variation in $\mathrm{HI}$ and $\mathrm{S} 2$ in Trail Lake sediments (figs. 5, 6D, and 9A) primarily is due to variable oxidation of algal organic matter in the water column.

The lakes in northern YNP are carbonate-rich and can contain up to $150 \mathrm{mg} / \mathrm{L} \mathrm{SO}_{4}$ (National Park Service, 1994); springs in that part of YNP often have a strong odor of $\mathrm{H}_{2} \mathrm{~S}$. The higher dissolved ions in northern YNP lakes are derived from Paleozoic carbonate-rock debris in glacial drift. Consequently, some sulfate reduction should be occurring in the hypolimnions of Blacktail Pond Fen and Slough Creek Pond (fig. 2). Bacterial POC depleted in ${ }^{13} \mathrm{C}$ resulting from sulfate reduction would explain the low values of $\delta^{13} \mathrm{C}$ (less than $-30 \%$ ) in the sediments of these lakes. The lowest values of $\delta^{13} \mathrm{C}$ in surface sediments from eight other lakes in YNP are from sediments of Lake of the Woods $(-31 \%$ ) and Grizzly Lake (-28.3\%o), both in northern YNP (fig. 2). Values of $\delta^{13} \mathrm{C}$ in sediments from Slough Creek Pond are all ${ }^{13} \mathrm{C}$-depleted, ranging from -27 to $-31 \%$, with a positive correlation with values of HI (fig. 9A; correlation is significant at the 95 percent confidence level). This positive trend is the opposite of what would be expected by mixing of terrestrial and algal organic matter. The OC-S2 plot for Slough Creek Pond (fig. 6B) indicates that the sediments in Slough Creek Pond contain a mixture of type I and type II organic matter, but all samples containing type II organic matter are close to the I-II line. The variation in $\mathrm{HI}$ and $\mathrm{S} 2$ in sediments from Slough Creek Pond (figs. 5, 6B, and 9A) could be due to oxidation of type I organic matter, as suggested by the negative HI-OI trend in figure 5, but the extremely ${ }^{13} \mathrm{C}$-depleted values of $\delta^{13} \mathrm{C}$ (less than 29\%o; fig. 9A) suggest that the POC in this lake is a mixture of $\mathrm{H}$-rich, more ${ }^{13} \mathrm{C}$-enriched algal $\mathrm{POC}$ from the epilimnion, and more ${ }^{13} \mathrm{C}$-depleted, less $\mathrm{H}$-rich bacterial POC from sulfate reduction in the hypolimnion.

The ${ }^{15} \mathrm{~N}$-depleted values of organic matter in the sediments of lakes in YNP (fig. 8) suggest that a large proportion of the organic matter in these lakes may be from $\mathrm{N}$-fixing 
phytoplankton (cyanobacteria). Prevalent $\mathrm{N}$-fixation would also imply that the lakes of YNP are nitrogen-limited. Values of $\delta^{15} \mathrm{~N}$ in sediments from Lake Minnetonka and Spectacle Lake in Minnesota (fig. 8) also are near zero suggesting that $\mathrm{N}$-utilization in these lakes also was mainly by $\mathrm{N}$-fixation. If nitrogen is not limiting, most $\mathrm{N}$-utilization by plankton is from nitrate $\left(\mathrm{NO}_{3}^{-}\right)$or ammonia $\left(\mathrm{NH}_{4}^{+}\right)$(Wetzel, 2001), which most likely explains the positive values of $\delta^{15} \mathrm{~N}$ in the lake sediments illustrated in figure 8 . The very ${ }^{15} \mathrm{~N}$-enriched values of $\delta^{15} \mathrm{~N}$ in sediments deposited over the last 100 years in Lake Baldegg in Switzerland (5\% to 13\%o; fig. 8) apparently are due to extreme nitrate utilization caused by eutrophication (Teranes and Bernasconi, 2000). They found, based on sediment-trap and historical data, that values of $\delta^{15} \mathrm{~N}$ increased with decreasing nitrate concentration in the water column. Increasing denitrification with the expansion of anoxia in the hypolimnion is another potential process that would increase the dissolved inorganic nitrogen pool in ${ }^{15} \mathrm{~N}$, and an increase in $\delta^{15} \mathrm{~N}$ of organic matter (Teranes and Bernasconi, 2000). (Collister and Hayes (1991) concluded that the existence of ${ }^{15} \mathrm{~N}$-enriched organic matter in the Green River Formation (fig. 8) requires a complex nitrogen cycle. They suggested that cyanobacterial assimilation of ammonia and nitrate, enriched in ${ }^{15} \mathrm{~N}$ by denitrification and nitrification (fig. 8), most likely accounts for ${ }^{15} \mathrm{~N}$-enrichment in the oil shale.

In Minnesota lakes, extremely ${ }^{13} \mathrm{C}$-depleted (less than $-29 \%$ o) organic matter occurs in the early and late Holocene sediments of Elk Lake, in all sediments of Shingobee Lake, in early Holocene sediments of Williams lake, and in late Holocene sediments of Green Lake (fig. 7). Today and in the early Holocene, Elk Lake was well stratified and at least seasonally anoxic; it may have been meromictic during the early Holocene (Dean and others, 2002). However, during the middle Holocene (prairie period), diatom evidence suggests that wind mixing likely kept the hypolimnion more oxic (Bradbury and Dieterich-Rurup, 1993; Dean and others, 2002). Values of HI in Elk Lake sediments are unusually low if the organic matter was derived from $\mathrm{H}$-rich algae (figs. 3 and 9B). One possible explanation is that much of the organic matter produced by photosynthesis in the epilimnion of Elk Lake is oxidized in the epilimnion (low HI), and is further decomposed in the thick, seasonally anoxic hypolimnion of this deep $(30 \mathrm{~m})$ lake. The $\mathrm{CO}_{2}$ produced by decomposition would then be available for chemoautotrophic bacteria to produce ${ }^{13} \mathrm{C}$-depleted, $\mathrm{H}$-poor bacterial POC. The distinctly more ${ }^{13} \mathrm{C}$-enriched organic matter deposited in sediments during the prairie period (fig. 9B) suggests that less bacterial POC was reaching the sediments. As discussed earlier, productivity in Elk Lake apparently was higher during the prairie period, perhaps producing more ${ }^{13} \mathrm{C}$-enriched photosynthetic POC; during the same time, the lake was more turbulent (wind-mixed), limiting microbial activity in a more oxic hypolimnion. Whatever the mechanism for the relatively ${ }^{13} \mathrm{C}$-enriched organic matter in prairie-period sediments, the low values of $\delta^{13} \mathrm{C}$ in all Holocene sediments in Elk Lake suggest that bacterial POC always was an important component to the sedimentary organic matter, particularly during the early and late Holocene when the lake was more stratified. At those times, Elk Lake may have been much like Lake Uinta during deposition of the Eocene Green River Formation (fig. 7), which also has a significant microbial biomass contribution (Collister and Hayes, 1991). During deposition of the sulfide-rich Green River Formation, sulfate reduction likely was the most important process in the saline, anoxic monimolimnion of Lake Uinta (Tuttle and Goldhaber, 1991), producing another source of ${ }^{13} \mathrm{C}$-depleted microbial biomass.

Shingobee Lake is eutrophic, and the hypolimnion becomes anoxic within a month after overturn in both the spring and fall (Dean and Schwalb, 2002). In late summer, the hypolimnion of Shingobee Lake contains up to $14,000 \mathrm{ppm}$ methane with a value of $\delta^{13} \mathrm{C}$ of up to $-73 \%$ o (R.G. Striegl, U.S. Geological Survey, unpublished data). In contrast, the hypolimnion of Williams Lake in late summer contains a maximum of $3,800 \mathrm{ppm}$ methane with a value of $\delta^{13} \mathrm{C}$ of up to $-52 \%$ (R.G. Striegl, unpublished data). During late summer, $\mathrm{CO}_{2}$ in the hypolimnion of Shingobee Lake is up to $4 \%$ more ${ }^{13} \mathrm{C}$-depleted than $\mathrm{CO}_{2}$ in the epilimnion. Clearly, ${ }^{13} \mathrm{C}$-depleted POC from methanotrophy is, and always has been, an important component to sedimentary organic matter in Shingobee.

As mentioned earlier, the surface sediments from Minnesota lakes that are the most ${ }^{13} \mathrm{C}$-depleted (ca. $-28 \%$ o to $-32 \%$ ) tend to contain the most algal organic matter, as indicated by plant pigments (fig. 7). Figures 9C and 9D show that the most ${ }^{13} \mathrm{C}$-depleted samples are the most $\mathrm{H}$-rich, and that the $\mathrm{H}$-rich samples have the highest total pigment concentrations.

The samples from Lake Minnetonka (fig. 1) are from the hypereutrophic North Arm of the lake, one of 15 basins that comprise the lake (Megard, 1972). These samples are highly enriched in ${ }^{13} \mathrm{C}\left(\delta^{13} \mathrm{C}-22 \%\right.$ o to $-26 \%$; fig. 7). The conditions in Lake Minnetonka might be like those in modern Lake Greifen where the production of ${ }^{13} \mathrm{C}$-enriched POC in the epilimnion in late summer overwhelms any ${ }^{13} \mathrm{C}$-depleted bacterial POC produced in the hypolimnion. In fact, the mean depth of the North Arm is only $4.3 \mathrm{~m}$ with a maximum depth of 14.0 $\mathrm{m}$ (Megard, 1972) so it is unlikely that this arm of the lake has much of a hypolimnion. Values of ${ }^{15} \mathrm{~N}$ are near zero (fig. 8) suggesting that the POC in the epilimnion is mostly produced by $\mathrm{N}$-fixing cyanobacteria. In Lower Lake Minnetonka, cyanobacteria are by far the dominant plankton, blooming mainly from July to October (Megard, 1972) when the $\mathrm{CO}_{2}$ in the epilimnion is likely to be the most ${ }^{13} \mathrm{C}$-enriched. The most ${ }^{13} \mathrm{C}$-depleted organic matter in Lake Minnetonka tends to be the most H-rich (fig. 9B), which also suggests that H-rich algal organic matter must be part of the POC mix in the sediments.

In Lake Greifen in Switzerland, cultural eutrophication, in response to increased nutrient loading (mainly phosphate), produced an anoxic hypolimnion after 1930 with the deposition of laminated sediments (Hollander and others, 1992). Organic matter in sediments deposited before 1930 was mostly produced by photosynthesis in the epilimnion and oxidized in the oxic hypolimnion resulting in $\mathrm{HI}$ values of 400-500 (fig. 10A). The slight negative correlation between $\delta^{13} \mathrm{C}$ and $\mathrm{HI}$ in sediments deposited before 1930 (fig. 10B) 

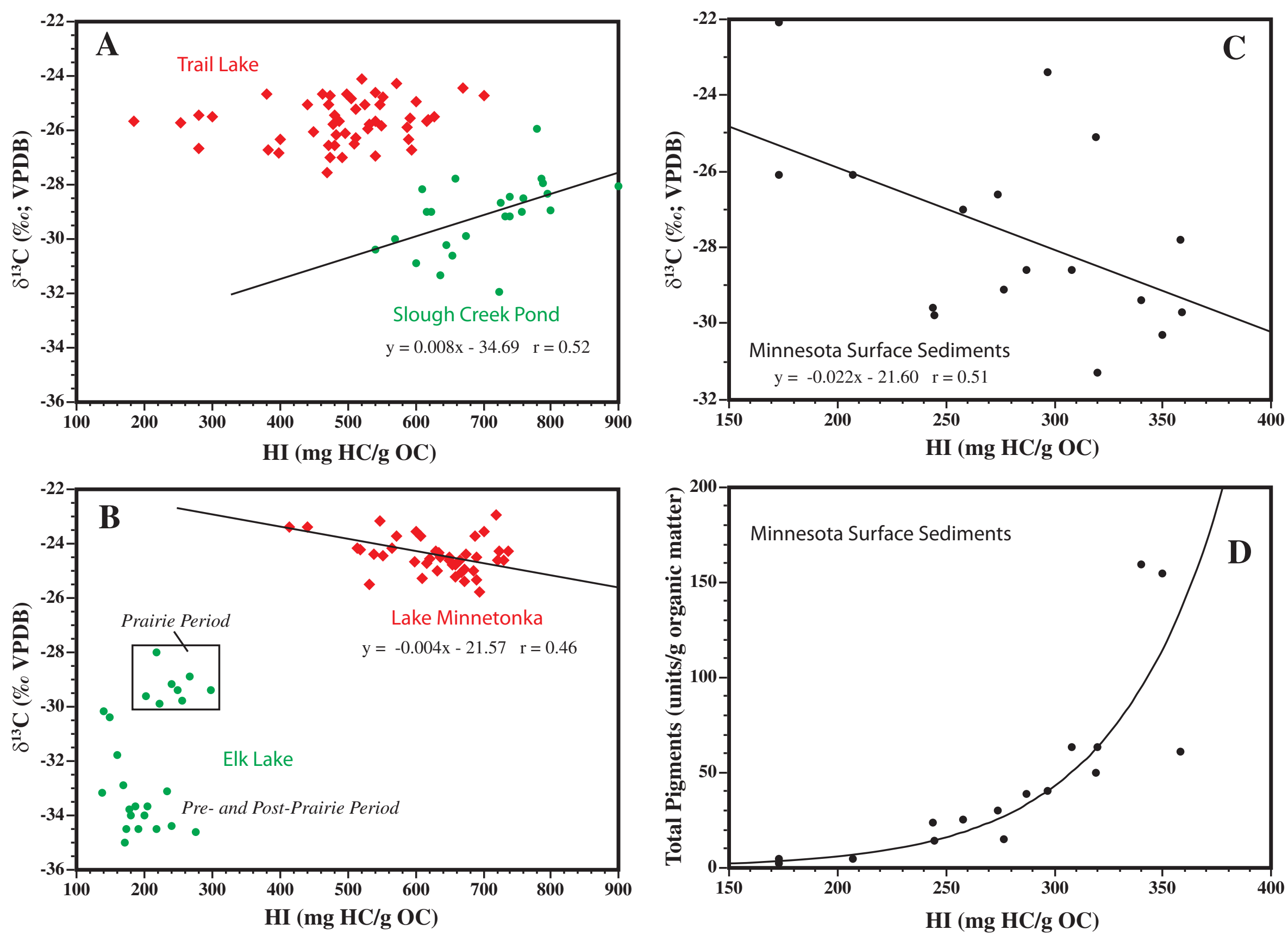

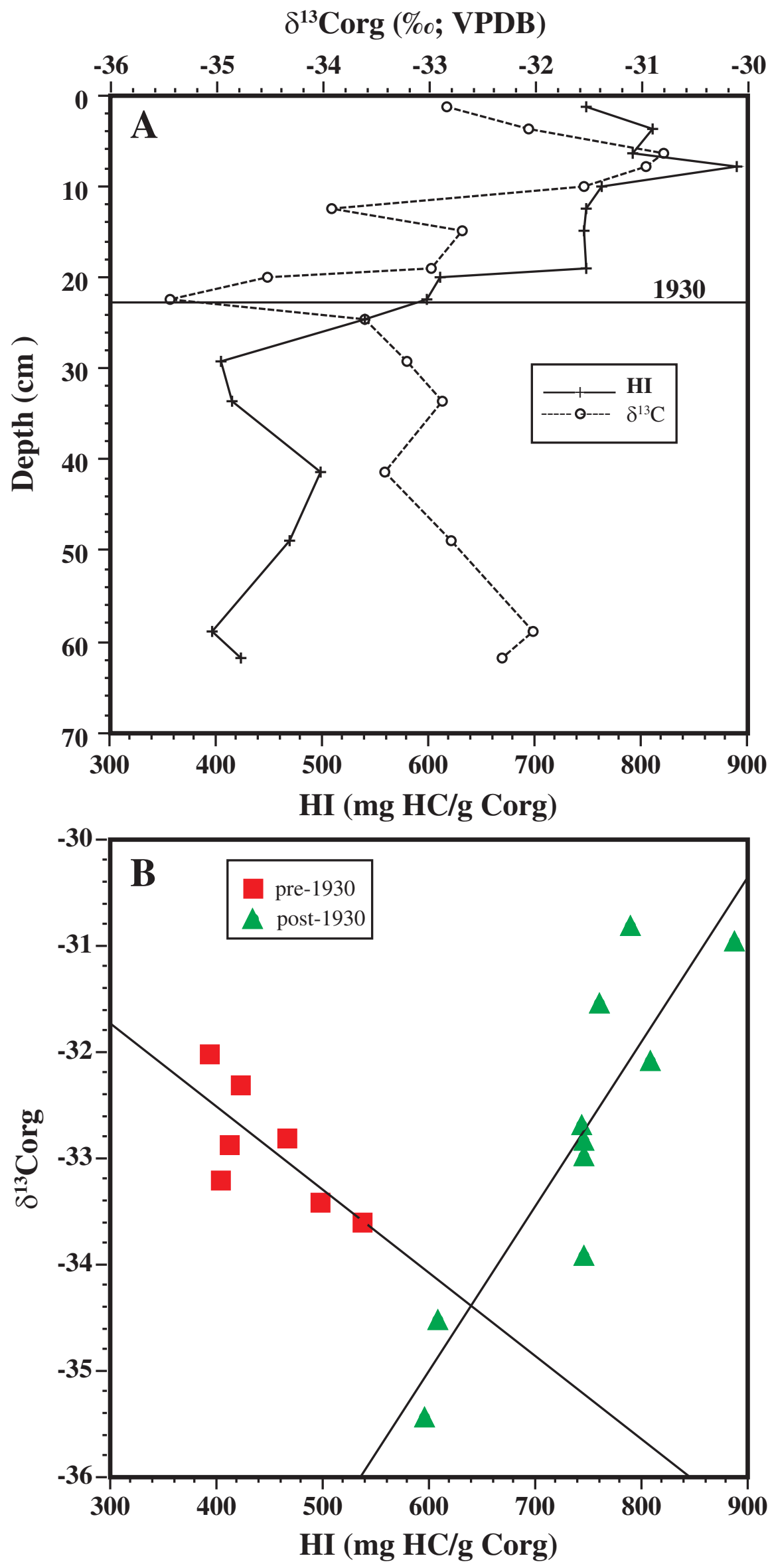

Figure 9. (previous page) Cross plots of Rock-Eval pyrolysis hydrogen index (HI) versus values $\delta^{13} \mathrm{C}$ in organic matter in lake sediments from $(A)$ Trail Lake and Slough Creek Pond in YNP; $(B)$ Lake Minnetonka and Elk Lake in Minnesota; (C) 18 Minnesota Lakes. A cross plot of HI versus concentrations of total plant pigments in surface sediments of the same 18 Minnesota lakes in shown in D. Data on pigments in surface sediments were provided by J.E. Sanger (see Sanger and Hay, 1993, for methods and interpretations of pigment results). VPDB, Vienna PeeDee Belemnite.

Figure 10. (left) Values of Rock-Eval pyrolysis hydrogen index and $\delta^{13} \mathrm{C}$ of organic matter in the top $60 \mathrm{~cm}$ of sediment from Lake Greifen in Switzerland are plotted in stratigraphic sequence $(A)$ and as a cross plot $(B)$. Data are from Hollander and others (1992). 
suggests that there was some mixing of terrestrial organic matter, but with predominantly aqueous organic matter (Hollander and others, 1992). The immediate post-1930 period of intense eutrophication with methanotrophy in the hypolimnion is represented in figure 10 by two samples with values of $\delta^{13} \mathrm{C}$ of less than $-34 \%$ and values of $\mathrm{HI}$ of about 600 . The lake then rapidly evolved to a condition whereby photoautotrophic production of ${ }^{13} \mathrm{C}$ - and $\mathrm{H}$-enriched biomass overwhelmed production of $\delta^{13} \mathrm{C}$-depleted microbial biomass, producing a mix of organic matter with values of $\delta^{13} \mathrm{C}$ greater than $-34 \%$ and values of $\mathrm{HI}$ greater than 750 (fig. 10B). The organic matter in sediments in hypereutrophic Lake Minnetonka are much more ${ }^{13} \mathrm{C}$-enriched than any in Lake Greifen (fig. 7), which suggests that any ${ }^{13} \mathrm{C}$-depleted microbial biomass that is produced in the hypolimnion is not significantly diluting the abundant ${ }^{13} \mathrm{C}$-enriched cyanobacterial biomass produced in the epilimnion in late summer.

Finally, the few studies that have addressed the effect of diagenesis on $\mathrm{C}$ - and $\mathrm{N}$-isotope composition have generally concluded that values of $\delta^{13} \mathrm{C}$ and $\delta^{15} \mathrm{~N}$ in sediments do record primary signals and are little affected by diagenesis. Dean and others (1986) concluded that a $1-2 \%$ o diagenetic ${ }^{13} \mathrm{C}$-depletion is possible in typical marine sediments, although they found no changes in down-core data from the Peru margin. Surdam and Stanley (1981) reported values of $\delta^{13} \mathrm{C}$ in amorphous, sapropelic kerogen from samples of the Miocene Monterey Formation. These rocks have undergone a considerable amount of diagenesis, and yet values of $\delta^{13} \mathrm{C}$ are all between $-20.3 \%$ o and $-23.6 \%$. If any imprint of diagenesis on the ${ }^{13} \mathrm{C}$ signature of organic matter were to occur, it should be present in the Monterey Formation. Galimov and others (1982) and Deines (1980) reviewed the effects of various diagenetic processes on values of $\delta^{13} \mathrm{C}$ in marine organic matter and found no evidence for diagenetic change. Cronin and Morris (1982) found no significant changes in $\delta^{13} \mathrm{C}$ with increasing diagenesis in OCrich sediments off Namibia. Meyers (1997) concluded that the absence of evidence of diagenetic shifts in values of $\delta^{13} \mathrm{C}$ in many lacustrine sediment records indicates that microbes and plankton utilize a large enough fraction of the carbon pool that a potentially significant diagenetic effect is minimal. Studies from Lake Ontario (Hodell and Schelske, 1998), Lake Baldegg (Teranes and Bernasconi, 2000), and Lake Lugano in Switzerland (Lehman and others, 2002), suggest that despite significant diagenetic loss of organic matter, values of $\delta^{13} \mathrm{C}$ and $\delta^{15} \mathrm{~N}$ in sediments are little affected.

\section{Conclusions}

Sediments in cores from many lakes show an inverse correlation between the concentrations of $\mathrm{CaCO}_{3}$ and OC. This is attributed, in part, to the lacustrine carbon pump in which carbon is fixed by photosynthesis in the epilimnion, thus removing $\mathrm{CO}_{2}$ and increasing the $\mathrm{pH}$ and dissolved $\mathrm{O}_{2}$. Respiration of this fixed organic carbon (OC) in the hypolimnion consumes $\mathrm{O}_{2}$, produces $\mathrm{CO}_{2}$, and lowers the $\mathrm{pH}$. The lower $\mathrm{pH}$ of the hypolimnion can result in the dissolution of much of the
$\mathrm{CaCO}_{3}$ produced in the epilimnion. More $\mathrm{CaCO}_{3}$ is dissolved at the sediment/water interface and in corrosive pore waters.

The OC and Rock-Eval pyrolysis S2 data for lake sediments used in this investigation show that the two variables are highly correlated, which probably indicates that most of the organic matter in these sediments is lipid-rich, algal, organic matter. Using the S2 peak as a measure of H-richness, the sediments from Spectacle Lake and Lake Minnetonka in Minnesota, and Slough Creek Pond and Trail Lake in YNP are the most H-rich, and sediments from Lake Pepin in Minnesota, presently a wide spot in the Mississippi River, are the least H-rich.

In a moderately eutrophic lake, organic carbon fixed by photosynthesis in the epilimnion will become more ${ }^{13} \mathrm{C}$ enriched during the entire growing season as ${ }^{13} \mathrm{C}$-depleted $\mathrm{CO}_{2}$, preferentially utilized by photoautotrophic phytoplankton, is continually being removed and fixed in ${ }^{13} \mathrm{C}$-depleted organic matter. Some of this ${ }^{13} \mathrm{C}$-depleted organic matter may be decomposed in the hypolimnion producing anoxia and ${ }^{13} \mathrm{C}$ depleted $\mathrm{CO}_{2}$. Methanogenesis in anoxic sediments can release a considerable amount of ${ }^{13} \mathrm{C}$-depleted methane to the hypolimnion. Chemoautotrophic or methanotrophic bacteria in the anoxic hypolimnion can further fractionate the carbon-isotopic signature producing extremely ${ }^{13} \mathrm{C}$-depleted bacterial biomass. Bacterial biomass by sulfate reduction in Eocene Lake Uinta probably was a significant contributor to the extremely ${ }^{13} \mathrm{C}$ depleted oil shale in the sulfide-rich Green River Formation $\left(\delta^{13} \mathrm{C}-30\right.$ to $-34 \%$ ). Lake sediments with values of $\delta^{13} \mathrm{C}$ less than $-28 \%$ likely contain a considerable amount of bacterial biomass produced in the hypolimnion. Sediments from several lakes in Minnesota included in this study (Elk, Williams, Shingobee, and Green) match this criterion, as do lakes in northern YNP with high concentrations of dissolved sulfate.

In highly eutrophic lakes, rapid removal of ${ }^{13} \mathrm{C}$-depleted photosynthetic biomass early in the growing season may cause the carbon pool of the epilimnion to become enriched in ${ }^{13} \mathrm{C}$ so that photosynthesis later in the growing season produces organic matter that is highly enriched in ${ }^{13} \mathrm{C}$, resulting in a net ${ }^{13} \mathrm{C}$-enriched sedimentary carbon pool. Lake Minnetonka and Spectacle Lake in Minnesota have the most ${ }^{13} \mathrm{C}$-enriched sediments (greater than $-25 \%$ ) of the lakes in this study.

The ${ }^{15} \mathrm{~N}$-depleted values of organic matter in the sediments of lakes in YNP suggest that a large proportion of the organic matter in these lakes may be from N-fixing cyanobacteria. Prevalent $\mathrm{N}$-fixation would also imply that the lakes of YNP are nitrogen- limited. Values of $\delta^{15} \mathrm{~N}$ in sediments from Lake Minnetonka and Spectacle Lake in Minnesota also are near zero, suggesting that $\mathrm{N}$-utilization in these lakes also was mainly by $\mathrm{N}$-fixation.

The few studies that have addressed the effect of diagenesis on $\mathrm{C}$ - and $\mathrm{N}$-isotope composition have generally concluded that values of $\delta^{13} \mathrm{C}$ and $\delta^{15} \mathrm{~N}$ in sediments are little affected by diagenesis. Apparently, the absence of evidence of diagenetic shifts in values of $\delta^{13} \mathrm{C}$ and $\delta^{15} \mathrm{~N}$ in marine and lacustrine sediment records indicates that microbes and plankton utilize a large enough fraction of the carbon pool that a potentially significant diagenetic effect is minimal. 


\section{Acknowledgments}

Samples of sediment from cores from Yellowstone National Park were provided by Cathy Whitlock, University of Oregon. Stephanie Brachfeld, University of Minnesota, provided samples from the long 1997 core from Lake Pepin. Dan Engstrom and Jim Almendinger, St. Croix Watershed Research Station, Minnesota, provided samples and data from one of the short cores (D2) from their grid of 25 cores from Lake Pepin. Kerry Kelts and Dawn Graber, Limnological Research Center, University of Minnesota, provided sediment samples from Spectacle Lake. Amy Myrbo, University of Minnesota, provided sediment samples from Lake Minnetonka and Green Lake. Lisa Doner provided valuable assistance in the laboratory. Carbon and nitrogen isotope ratios were determined by Matt Emmons of Mountain Mass Spectrometry, Evergreen, Colorado. Rock-Eval pyrolysis analyses were conducted by Ted Daws in the USGS Organic Geochemistry lab, Denver Colo. The studies of Williams, Shingobee, and Pickerel Lakes could never have been done without Antje Schwalb, as well as Tom Winter, Don Rosenberry, Renee Parkhurst, Rob Striegl, and other members of the USGS Shingobee Headwaters study group. A special thanks to Dave Hollander for his many insights into the interpretation of carbon isotopes in lake sediments. This study was funded by the USGS Global Change and Climate History and Earth Surface Dynamics Programs. Reviews of an earlier draft of this paper by Janet Pitman, Mike Lewan, and Phil Meyers were most helpful and are greatly appreciated.

\section{References}

Arthur, M.A., Dean, W.E., Neff, E.D., Hay, B.J., Jones, G., and King, J., 1994, Late Holocene (0-2000 y BP) organic carbon accumulation in the Black Sea: Global Biogeochemical Cycles, v. 8, p. 195-217.

Baker, R.G., Gonzalez, L.A., Raymo, M., Bettis, A., III, Reagan, M.K., and Dorale, J.A., 1998, Comparison of multiple proxy records of Holocene environments in the midwestern United States: Geology, v. 26, p. 1135-1138.

Bender, M.M., 1971, Variations in the ${ }^{13} \mathrm{C} /{ }^{12} \mathrm{C}$ ratios of plants in relation to the pathway of photosynthetic carbon dioxide fixation: Phytochemistry, v. 10, p. 1239-1343.

Brachfeld, S., and Banerjee, S., 2000, A new high-resolution geomagnetic paleointensity record for the North American Holocene-A comparison of sedimentary and absolute intensity data: Journal of Geophysical Research, B, v. 105, p. 821-834.

Bradbury, J.P., and Dieterich-Rurup, K., 1993, Holocene diatom paleolimnology of Elk Lake, Minnesota, in Bradbury, J.P., and Dean, W.E., eds., Elk Lake, Minnesota - Evidence for rapid climate change in the north-central United States: Geological Society of America, Special Paper 276, p. 215-238.
Brunskill, G.J., Povoledo, J.D., Graham, B.W., and Stainton, M.P., 1971, Chemistry of surface sediments of sixteen lakes in the Experimental Lakes Area, northwestern Ontario: Journal of the Fisheries Research Board of Canada, v. 28, p. 77-294.

Calvert, S.E., Karlin, R.E., Toolin, L.J., Donahue, D.J., Southon, J.R. and Vogel, J.S., 1991, Low organic carbon accumulation rates in Black Sea sediments: Nature, v. 350, p. 692-695.

Cerling, T.E., and Quade, J., 1993, Stable carbon and oxygen isotopes in soil carbonates, in Swart, P.K., Lohmann, K.C., McKenzie, J., and Savin, S., eds., Climate change in continental isotopic records: American Geophysical Union, Geophysical Monograph 78, p. 217-231.

Collister, J.W., and Hayes, J.M., 1991, A preliminary study of the carbon and nitrogen isotope biogeochemistry of lacustrine sedimentary rocks from the Green River Formation, Wyoming, Utah, and Colorado: U.S. Geological Survey Bulletin 1973-C, 16 p.

Cronin, J.R., and Morris, R.J., 1982, The occurrence of high molecular weight humic material from Recent organic-rich sediment from the Namibian shelf: Estuarine, Coastal, and Shelf Science, v. 15, p. 17-27.

Dean, W.E., 1981, Carbonate minerals and organic matter in sediments of modern North Temperate hard-water lakes, in Ethridge, F.G., and Flores, R.M., eds., Recent and ancient nonmarine depositional environments-Models for exploration: Society of Economic Paleontologists and Mineralogists Special Publication 31, p. 177-195.

Dean, W.E., 1993, Physical properties, mineralogy, and geochemistry of Holocene varved sediments from Elk Lake, Minnesota, in Bradbury, J.P., and Dean, W.E., eds., Elk Lake, Minnesota-Evidence for rapid climate change in the north-central United States: Geological Society of America, Special Paper 276, p. 135-157.

Dean, W.E., 1999, The carbon cycle and biogeochemical dynamics in lake sediments: Journal of Paleolimnology, v. 21 , p. $375-393$

Dean, W.E., and Anders, D.E., 1991, Effects of source, depositional environment, and diagenesis on characteristics of organic matter in oil shale from the Green River Formation, Wyoming, Utah, and Colorado.U.S. Geological Survey Bulletin 1973-F, 16 p.

Dean, W.E., Arthur, M.A., and Claypool, G.E., 1986, Depletion of ${ }^{13} \mathrm{C}$ in Cretaceous marine organic matter-Source, diagenetic, or environmental signal?: Marine Geology, v. 70, p. 119-158.

Dean, W.E., and Bradbury, J.P., 1997, Transects of organic carbon, calcium carbonate, and diatoms in surface sediments of 
Williams and Shingobee Lakes, in Interdisciplinary Research Initiative: Hydrological and biogeochemical research in the Shingobee River headwaters area, north-central Minnesota: U. S. Geological Survey Water Resources Investigations Research 96-4215, p. 117-129.

Dean, W.E., Forester, R.M., and Bradbury, J.P., 2002, Early Holocene change in atmospheric circulation in the Northern Great Plains-An upstream view of the 8.2 ka cold event: Quaternary Science Reviews, v. 21, p. 1763-1775.

Dean, W.E., and Gardner, J.V., 1998, Pleistocene to Holocene contrasts in organic matter production and preservation on the California continental margin: Geological Society of America Bulletin, v. 110, p. 888-899.

Dean W.E., and Gorham, E., 1976, Major components of Minnesota lake sediments: Limnology and Oceanography, v. 21, p. 259-284.

Dean, W.E., Gorham, E., and Sanger, J.E., 1988, Geochemistry of surface sediments of lakes in the English Lake District, in Round, F.E., ed., Algae and the aquatic environment: Bristol, Biopress Ltd., p. 244-271.

Dean, W.E., Gorham, E., and Swaine, D.J., 1993, Geochemistry of surface sediments of Minnesota lakes, in Bradbury, J.P., and Dean, W.E., eds., Elk Lake, MinnesotaEvidence for rapid climate change in the north-central United States: Geological Society of America, Special Paper 276, p. 115-134.

Dean, W.E., Neff, B., Rosenberry, D., Winter, T.C., and Parkhurst, R., 2003, The significance of ground water to the accumulation of iron and manganese in the sediments of two hydrologically distinct lakes in north-central Minnesota-A geological perspective: Ground Water, v. 41, p. 951-963.

Dean, W.E., and Schwalb, A., 2000, Holocene environmental and climatic change in the Northern Great Plains as recorded in the geochemistry of sediments in Pickerel Lake, South Dakota: Quaternary International, v. 67, p. 5-20.

Dean, W.E., and Schwalb, A., 2002, The lacustrine carbon cycle as illuminated by the waters and sediments of two hydrologically distinct hardwater lakes in northwestern Minnesota: Journal of Sedimentary Research, v. 72, p. 416-431.

Dean, W.E., and Stuiver, M., 1993, Stable carbon and oxygen isotope studies of the sediments of Elk Lake, Minnesota, in Bradbury, J.P., and Dean, W.E., eds., Elk Lake, MinnesotaEvidence for rapid climate change in the north-central United States: Geological Society of America, Special Paper 276, p. 163-180.

Deines, P., 1980, The isotopic composition of reduced organic carbon, in Fritz, P., and Fontes, J.C., eds., Handbook of environmental isotope geochemistry, Vol. 1, The terrestrial environment: Amsterdam, Elsevier, p. 329-406.
Engleman, E.E., Jackson, L.L., Norton, D.R., and Fischer, A.G., 1985, Determination of carbonate carbon in geological materials by coulometric titration: Chemical Geology, v. 53, p. 125-128.

Engstrom, D.R., and Almendinger, J.E., 1997, Historical changes in sediment and phosphorus loading to the Upper Mississippi River-Mass balance reconstructions from the sediments of Lake Pepin. Final Research Report prepared for the Metropolitan Council Environmental Services, 43 p.

Galimov, E.M., Kodina, L.A., Bogacheva, M.P., and Shirinsky, V.G., 1982, Organic geochemical studies of samples from Deep Sea Drilling Project Leg 64, Gulf of California, Sites 474, 477, 478, 479, and 481, in Curray, J.R., Moore, D.G, and others, Initial reports of the Deep Sea Drilling Project, v. 64, U.S. Government Printing Office, Washington, D.C., p. 819-836.

Gorham, E., Dean, W.E., and Sanger, J.E., 1983, The chemical composition of lakes in the north-central United States: Limnology and Oceanography, v. 28, p. 287-301.

Gorham, E.J., Lund, J.W.G., Sanger, J.E., and Dean, W.E., 1974, Some relationships between algal standing crop, water chemistry, and sediment chemistry in the English lakes: Limnology and Oceanography, v. 19, p. 601-617.

Gorham, E., and Sanger, J.E., 1975, Fossil pigments in Minnesota lake sediments and their bearing upon the balance between terrestrial and aquatic inputs to sedimentary organic matter: Verhandlungen der Internationalen Vereinigung fur Theoretische und Angewandt Limnologie, v. 19, p. 2267-2273.

Hansen, K., 1959, The terms Gyttja and Dy: Hydrobiologie, v. 15, p. 1873.

Hoch, A.R., Reddy, M.M., and Aiken, G.R., 1999, Calcite crystal growth inhibition by humic substances with emphasis on hydrophobic acids from the Florida Everglades: Geochimica et Cosmochimica Acta, v. 64, p. 61-72.

Hodell, D.A., and Schelske, C.L., 1998, Production, sedimentation, and isotopic composition of organic matter in Lake Ontario: Limnology and Oceanography, v. 43, p. 200-214.

Hollander, D.J., and McKenzie, J.A., 1991, CO 2 control on carbon-isotope fractionation during aqueous photosysthesis-A paleo- $\mathrm{pCO}_{2}$ barometer: Geology, v. 19, p. 929-932.

Hollander, D.J., McKenzie, J.A., and ten Haven, H.L., 1992, A 200-year sedimentary record of progressive eutrophication in Lake Greifen (Switzerland)-Implications for the origin of organic-carbon-rich sediments: Geology, v. 20, p. $825-828$.

Hollander, D.J., and Smith, M.A., 2001, Microbially mediated carbon cycling as a control on the $\delta^{13} \mathrm{C}$ of sedimentary 
carbon in eutrophic Lake Mendota (USA)_-New models for interpreting isotopic excursions in the sedimentary record: Geochimica et Cosmochimica Acta, v. 65, p. 4321-4337.

Kemp, A. L., Thomas, W.R.L, Wong, H.K.T., and Johnson, L.M., 1977, Nitrogen and C/N ratios in the sediments of Lakes Superior, Huron, St. Claire, Erie, and Ontario: Canadian Journal of Earth Sciences: v. 14, p. 2402-2413.

Konrad, J.G., Keeney, D.R., Chesters, D.R.G., and Chen, K.L., 1970, Nitrogen and carbon distribution in sediment cores of selected Wisconsin lakes: Journal of Water Pollution Control Federation, v. 42, p. 2094-2101.

Langford, F.F., and Blank-Vallaron, M.M., 1990, Interpreting Rock-Eval pyrolysis data using graphs of pyrolizable hydrocarbons vs. total organic carbon: American Association of Petroleum Geologists Bulletin, v. 74, p. 799-804.

Lehman, M.F., Bernasconi, S.M., Barbieri, A., and McKenzie, J.A., 2002, Preservation of organic matter and alteration of its carbon and nitrogen isotope composition during simulated and in situ early sedimentary diagenesis: Geochimica et Cosmochimica Acta v. 66, p. 3573-3584.

Liebezeit, G., and Wiesner, M.G., 1990, Pyrolysis of Recent marine sediments I. Biopolymers. in Burand B., and Béhar, F., eds., Advances in organic geochemistry 1989, Part II-Molecular geochemistry: Organic Geochemistry, v. 16, p. 1179-1185.

Locke, S.M., 1995, A paleohydrologic model applied to the Holocene stratigraphy of two lakes in north-central Minnesota: University of Minnesota, Ph.D. dissertation, 258 p.

Mackereth, F.J.M., 1966, Some chemical observations on postglacial lake sediments: Royal Society of London, Philosophical Transactions, Ser. B, v. 250, p. 165-213.

McConnaughey, T.A., LaBaugh, J.W., Rosenberry, D.O., Reddy, M.M., Schuster, P.F., and Carter. V., 1994, Carbon budget for a groundwater-fed lake-Calcification supports summer photosynthesis: Limnology and Oceanography, v. 39, p. 1319-1332.

McKenzie, J.A., 1985, Carbon isotopes and productivity in the lacustrine and marine environment, in Stumm, W., ed., Chemical processes in lakes: New York, Wiley, p. 99-118.

Megard, R.O., 1972, Phytoplankton, photosynthesis, and phosphorus in Lake Minntonka in Minnesota: Limnology and Oceanography, v. 17, p. 68-87.

Megard, R.O., Bradbury, J.P., and Dean, W.E., 1993, Climatic and limnologic setting of Elk Lake, in Bradbury, J.P., and Dean, W.E., eds., Elk Lake, Minnesota-Evidence for rapid climate change in the north-central United States: Geological Society of America, Special Paper 276, p. 19-36.
Meyers, P.A., 1997, Organic geochemical proxies in paleoceanographic, paleolimnologic, and paleoclimatic processes: Organic Geochemistry, v. 27, p. 2113-250.

Meyers, P.A., and Ishiwatari, R., 1993, Lacustrine organic geochemistry-An overview of indicators of organic matter sources and diagenesis in lake sediments: Organic Geochemistry, v. 20, p. 867-900.

Moore, D.M., and Reynolds, R.C., Jr., 1997, X-ray diffraction and the identification and analysis of clay minerals: Oxford University Press, 378 p.

Molot, L.A., and Dillon, P.J., 1996, Storage of terrestrial carbon in boreal lake sediments and evasion to the atmosphere: Global Biogeochemical Cycles, v. 10, p. 483-492.

National Park Service, 1994, Baseline water quality data, inventory and analysis, Yellowstone National Park: Technical Report NPS/NRWRD/NRTR 94/22, 941 p.

Oana, S., and Deevey, E.S., 1960, Carbon-13 in lake waters and its possible bearing on paleolimnology: American Journal of Science, v. 258-A, p. 253-272.

O'Leary, M.H., 1988, Carbon isotopes in photosynthesis: BioScience, v. 38, p. 328-336.

Pederson, T.F., Shimmield, G.B. and Price, N.B., 1992, Lack of enhanced preservation of organic-matter in sediments under the oxygen minimum on the Oman Margin: Geochimica et Cosmochimica Acta, v. 56, p. 545-551.

Peters, K.E., 1986, Guidelines for evaluating petroleum source rock using programmed pyrolysis: American Association of Petroleum Geologists Bulletin, v. 70, p. 318-329.

Rau, G.R., Arthur, M.A., and Dean, W.E., $1987,{ }^{15} \mathrm{~N} /{ }^{14} \mathrm{~N}$ variations in Cretaceous Atlantic sedimentary sequences-Implications for past changes in marine nitrogen biogeochemistry: Earth Planetary Science Letters v. 82, p. 269-279.

Sanger, J.E., and Gorham, E., 1970, The diversity of pigments in lake sediments and its ecological significance: Limnology and Oceanography, v. 15, p. 59-69.

Sanger, J.E., and Hay, R., 1993, Fossil pigments in Holocene varved sediments in Elk Lake, Minnesota, in Bradbury, J.P., and Dean, W.E., eds., Elk Lake, Minnesota-Evidence for rapid climate change in the north-central United States: Geological Society of America, Special Paper 276, p. 181-188.

Schwalb, A., and Dean, W.E., 1998, Stable isotopes and sediments from Pickerel Lake, South Dakota, USA: Journal of Paleolimnology, v. 20, p. 5-30. 
Schwalb, A., and Dean, W.E., 2002, Reconstruction of hydrological changes and effective moisture from north-central USA lake sediments: Quaternary Sciences Reviews, v. 21, p. 1541-1554.

Schwalb, A., Locke, S.M., and Dean, W.E., 1995, Ostracode $\delta^{18} \mathrm{O}$ and $\delta^{13} \mathrm{C}$ evidence of Holocene environmental changes in the sediments of two Minnesota lakes: Journal of Paleolimnology, v. 14, p. 281-296.

Striegl, R.G., and Michmerhuizen, C.M., 1997, Methane emission from Minnesota and Wisconsin lakes following icemelt, in Winter, T.C. ed., Interdisciplinary Research Initiative-Hydrological and biogeochemical research in the Shingobee River headwaters area, north-central Minnesota: U.S. Geological Survey, Water Resources Investigations Report 96-4215, p. 77-81.

Summons, R.E., Jahnke, L.L., and Roksandic, Z., 1994, Carbon isotope fractionation in lipids from methanotropic bacteria-Relevance for interpretations of the geochemical record of biomarkers: Geochimica et Cosmochimica Acta, v. 58, p. 2853-2863.

Surdam, R.C., and Stanley, K.G., 1981, Diagenesis and migration of hydrocarbons in the Monterey Formation, Pismo Syncline, California, in Garrison, R.E., and Douglas, R.G., eds., The Monterey Formation and related siliceous rocks of California: Pacific Section, Society of Economic Paleontologists and Mineralogists, Special Publication 15, p. 317-327.

Teranes, J.L., and Bernasconi, S.M., 2000, The record of nitrate utilization and productivity limitation provided by $\delta^{15} \mathrm{~N}$ values in lake organic matter-A study of sediment trap and core sediments from Baldeggersee, Switzerland: Limnology and Oceangraphy, v. 45, p. 801-813

Tissot, B.P. and Welte, D.H., 1984, Petroleum formation and occurrence, 2d ed.: New York, Springer-Verlag, 538 p.

Tuttle, M.L., and Goldhaber, M.B., 1991, Sulfur geochemistry and isotopy of the Green River Formation, Wyoming, Utah, and Colorado: U.S. Geological Survey Bulletin 1973-B, 20 p.

Webb, T., III, Cushing, E.J., and Wright, H.E., Jr., 1983, Holocene changes in vegetation of the Midwest. in Wright, H. E., Jr., ed., Late Quaternary environments of the United States, Volume 2, The Holocene: Minneapolis, University of Minnesota Press, p. 142-165.

Wetzel, R.G., 2001, Limnology, 3d ed.: San Diego, Academic Press, 1006 p.
Whelen, J.K. and Thompson-Rizer, C.L., 1993, Chemical methods for assessing kerogen and protokerogen types and maturity, in Engel M.H., and Macko, S.A., eds., Organic Geochemistry-Principles and Applications: New York, Plenum Press, p. 289-353.

Whiticar, M.J., Faber, J.E., and Schoell, M., 1986, Biogenic methane formation in marine and freshwater environments$\mathrm{CO}_{2}$ reduction vs. acetate fermentation-Isotopic evidence: Geochimica et Cosmochimica Acta, v. 50, p. 693-709.

Whitlock, C., and Millspaugh, S.H., 1996, Testing the assumptions of fire-history studies-An examination of modern charcoal accumulation in Yellowstone National Park, USA: The Holocene, v. 6, p. 7-15.

Whitlock, C., Bartlein, P.J., and Watts, W.A., 1993, Vegetation history of Elk Lake, in Bradbury, J.P., and Dean, W.E., eds., Elk Lake, Minnesota-Evidence for rapid climate change in the north-central United States: Geological Society of America, Special Paper 276, p. 251-274.

Wright, H.E., Jr., 1967, A square-rod piston sampler for lake sediments: Journal of Sedimentary Petrology, v. 3, p. 975-976.

Wright, H.E., Lease, K., and Johnson, S., 1998, Glacial River Warren, Lake Pepin, and the environmental history of southeastern Minnesota, in Patterson, C.J., and Wright, H.E., Jr., eds., Contributions to the Quaternary geology of Minnesota: Minnesota Geological Survey Report of Investigations 49, p. 131-140. 
Appendix 1. Results of carbon analyses.

\begin{tabular}{|c|c|c|c|}
\hline $\begin{array}{c}\begin{array}{c}\text { Depth } \\
\text { (centimeters) }\end{array} \\
\text { cols }\end{array}$ & $\begin{array}{c}\text { Total C } \\
\text { (percent) }\end{array}$ & $\begin{array}{l}\text { Inorg. C } \\
\text { (percent) }\end{array}$ & $\begin{array}{l}\text { Org. C } \\
\text { (percent) }\end{array}$ \\
\hline \multicolumn{4}{|l|}{ Williams Lake } \\
\hline 18 & 32.84 & 0.01 & 32.83 \\
\hline 38 & 33.20 & 0.01 & 33.19 \\
\hline 58 & 32.27 & 0.03 & 32.24 \\
\hline 85 & 30.98 & 0.01 & 30.97 \\
\hline 105 & 31.54 & 0.01 & 31.53 \\
\hline 125 & 34.84 & 0.01 & 34.82 \\
\hline 145 & 32.53 & 0.01 & 32.52 \\
\hline 162 & 31.49 & 0.04 & 31.45 \\
\hline 182 & 33.97 & 0.01 & 33.96 \\
\hline 202 & 32.06 & 0.01 & 32.06 \\
\hline 220 & 32.35 & 0.02 & 32.34 \\
\hline 240 & 28.99 & 0.01 & 28.98 \\
\hline 260 & 29.24 & 0.01 & 29.22 \\
\hline 280 & 26.59 & 0.01 & 26.58 \\
\hline 300 & 24.65 & 0.02 & 24.64 \\
\hline 318 & 19.08 & 0.49 & 18.59 \\
\hline 325 & 12.78 & 2.93 & 9.84 \\
\hline 338 & 15.14 & 3.07 & 12.07 \\
\hline 359 & 10.58 & 0.95 & 9.62 \\
\hline 365 & 8.89 & 3.78 & 5.11 \\
\hline 388 & 9.39 & 4.35 & 5.03 \\
\hline 408 & 7.50 & 4.10 & 3.40 \\
\hline 428 & 7.05 & 4.28 & 2.77 \\
\hline 448 & 6.87 & 4.32 & 2.55 \\
\hline 468 & 11.09 & 4.94 & 6.15 \\
\hline 478 & 7.89 & 4.82 & 3.08 \\
\hline 487 & 7.92 & 5.07 & 2.86 \\
\hline 493 & 8.05 & 4.00 & 4.05 \\
\hline 499 & 8.67 & 4.30 & 4.37 \\
\hline 503 & 8.10 & 4.99 & 3.12 \\
\hline 513 & 7.21 & 5.07 & 2.14 \\
\hline 533 & 6.86 & 5.15 & 1.71 \\
\hline 536 & 8.22 & 6.02 & 2.20 \\
\hline
\end{tabular}

\begin{tabular}{cccc}
\hline $\begin{array}{c}\text { Depth } \\
\text { (centimeters) }\end{array}$ & $\begin{array}{c}\text { Total C } \\
\text { (percent) }\end{array}$ & $\begin{array}{c}\text { Inorg. Cercent) } \\
\text { (percent) }\end{array}$ \\
\hline 546 & 7.39 & 4.93 & 2.47 \\
554 & 4.96 & 4.25 & 0.71 \\
562 & 3.28 & 2.99 & 0.29 \\
563 & 7.32 & 5.80 & 1.52 \\
578 & 5.50 & 4.41 & 1.10 \\
584 & 4.47 & 3.55 & 0.92 \\
588 & 5.37 & 4.13 & 1.24 \\
593 & 6.08 & 4.35 & 1.74 \\
598 & 4.90 & 4.19 & 0.70 \\
603 & 3.65 & 2.89 & 0.76 \\
608 & 7.88 & 6.20 & 1.68 \\
613 & 7.95 & 6.18 & 1.77 \\
623 & 7.85 & 6.57 & 1.27 \\
633 & 8.67 & 7.59 & 1.08 \\
643 & 9.36 & 8.36 & 1.00 \\
653 & 8.92 & 8.17 & 0.74 \\
660 & 10.30 & 8.71 & 1.59 \\
676 & 11.81 & 10.01 & 1.80 \\
686 & 12.70 & 10.26 & 2.43 \\
696 & 11.16 & 9.66 & 1.50 \\
706 & 9.58 & 8.39 & 1.19 \\
712 & 10.91 & 10.32 & 0.60 \\
Shingobee Lake & & & \\
0 & 13.43 & 7.54 & 5.89 \\
14 & 13.28 & 8.08 & 5.20 \\
34 & 13.57 & 8.51 & 5.06 \\
54 & 13.01 & 8.17 & 4.83 \\
74 & 12.98 & 9.46 & 3.52 \\
94 & 12.88 & 10.08 & 2.80 \\
114 & 12.88 & 10.10 & 2.79 \\
134 & 13.02 & 9.40 & 3.62 \\
154 & 13.17 & 9.37 & 3.80 \\
174 & 12.77 & 9.01 & 3.76 \\
191 & 12.90 & 8.89 & 4.01 \\
201 & 12.57 & 8.75 & 3.82 \\
216 & 11.79 & 7.62 & 4.17 \\
236 & 12.09 & 8.50 & 3.59 \\
246 & 11.97 & 7.84 & 4.13 \\
266 & 12.10 & 8.49 & 3.61 \\
290 & 11.82 & 7.81 & 4.01 \\
306 & 10.49 & 7.02 & 3.47 \\
326 & 11.20 & 8.12 & 3.08 \\
& & & \\
\hline 54 & &
\end{tabular}


Appendix 1. Results of carbon analyses.-Continued

\begin{tabular}{|c|c|c|c|c|c|c|c|}
\hline $\begin{array}{c}\text { Depth } \\
\text { (centimeters) }\end{array}$ & $\begin{array}{c}\text { Total C } \\
\text { (percent) }\end{array}$ & $\begin{array}{l}\text { Inorg. C } \\
\text { (percent }\end{array}$ & $\begin{array}{c}\text { Org. C } \\
\text { (percent) }\end{array}$ & $\begin{array}{c}\text { Depth } \\
\text { (centimeters) }\end{array}$ & $\begin{array}{c}\text { Total C } \\
\text { (percent) }\end{array}$ & $\begin{array}{l}\text { Inorg. C } \\
\text { (percent) }\end{array}$ & $\begin{array}{c}\text { Org. C } \\
\text { (percent) }\end{array}$ \\
\hline 346 & 10.64 & 7.68 & 2.96 & 98 & 16.10 & 7.91 & 8.19 \\
\hline 366 & 11.44 & 8.76 & 2.68 & 120 & 16.38 & 8.47 & 7.90 \\
\hline 396 & 10.54 & 7.69 & 2.85 & 140 & 15.53 & 9.25 & 6.28 \\
\hline 416 & 9.47 & 7.44 & 2.04 & 160 & 15.05 & 9.21 & 5.84 \\
\hline 436 & 10.02 & 7.92 & 2.11 & 180 & 15.95 & 9.15 & 6.80 \\
\hline 456 & 11.03 & 8.65 & 2.38 & 120 & 15.44 & 9.22 & 6.22 \\
\hline 476 & 11.24 & 9.01 & 2.23 & 140 & 15.59 & 9.44 & 6.15 \\
\hline 496 & 11.44 & 9.23 & 2.21 & 160 & 14.86 & 9.58 & 5.28 \\
\hline 506 & 11.35 & 9.25 & 2.11 & 170 & 14.74 & 9.69 & 5.05 \\
\hline 516 & 10.53 & 9.30 & 1.22 & 190 & 13.97 & 9.11 & 4.86 \\
\hline 536 & 10.69 & 8.58 & 2.11 & 210 & 12.92 & 8.14 & 4.78 \\
\hline 556 & 10.69 & 8.66 & 2.03 & 170 & 12.37 & 8.24 & 4.14 \\
\hline 566 & 11.06 & 9.20 & 1.86 & 180 & 11.81 & 7.86 & 3.95 \\
\hline 596 & 10.38 & 8.59 & 1.79 & 190 & 11.90 & 7.80 & 4.10 \\
\hline 606 & 10.01 & 8.27 & 1.74 & 200 & 12.29 & 7.95 & 4.34 \\
\hline 626 & 10.66 & 8.77 & 1.88 & 210 & 11.64 & 7.23 & 4.41 \\
\hline 636 & 10.68 & 8.84 & 1.84 & 220 & 11.93 & 6.91 & 5.02 \\
\hline 656 & 10.29 & 8.56 & 1.73 & Spectacle Lake & & & \\
\hline 676 & 10.29 & 8.52 & 1.77 & 2 & 23.02 & & \\
\hline 695 & 10.57 & 8.52 & 2.05 & 12 & 20.78 & & \\
\hline 715 & 10.71 & 9.17 & 1.55 & 22 & 21.08 & & \\
\hline 735 & 10.36 & 9.07 & 1.29 & 32 & 27.30 & & \\
\hline 755 & 11.40 & 9.89 & 1.51 & 42 & 30.93 & & \\
\hline 775 & 8.39 & 6.57 & 1.83 & 52 & 34.15 & & \\
\hline 794 & 11.55 & 9.68 & 1.88 & 62 & 34.95 & & \\
\hline 812 & 11.71 & 9.86 & 1.85 & 72 & 36.29 & & \\
\hline 832 & 10.90 & 8.92 & 1.98 & 82 & 34.48 & & \\
\hline 852 & 10.47 & 8.64 & 1.83 & 92 & 34.80 & & \\
\hline 870 & 11.48 & 9.18 & 2.31 & 105 & 34.06 & & \\
\hline 885 & 11.10 & 9.15 & 1.95 & 113 & 32.09 & & \\
\hline 897 & 10.97 & 9.02 & 1.96 & 123 & 30.25 & & \\
\hline 917 & 10.75 & 7.99 & 2.76 & 133 & 30.41 & & \\
\hline 925 & 7.79 & 6.57 & 1.22 & 143 & 25.76 & & \\
\hline Green Lake & & & & 153 & 29.49 & & \\
\hline 20 & 17.61 & 3.48 & 14.13 & 163 & 30.82 & & \\
\hline 30 & 18.18 & 3.76 & 14.42 & 173 & 34.12 & & \\
\hline 40 & 17.69 & 5.34 & 12.35 & 183 & 32.11 & & \\
\hline 50 & 17.18 & 5.12 & 12.06 & 193 & 32.27 & & \\
\hline 60 & 16.61 & 5.09 & 11.52 & 211 & 33.15 & & \\
\hline 70 & 14.91 & 5.75 & 9.15 & 334 & 32.76 & & \\
\hline 80 & 14.94 & 7.10 & 7.84 & 344 & 32.28 & & \\
\hline 90 & 15.80 & 8.26 & 7.54 & 359 & 30.94 & & \\
\hline
\end{tabular}


Appendix 1. Results of carbon analyses.-Continued

\begin{tabular}{cccc}
\hline $\begin{array}{c}\text { Depth } \\
\text { (centimeters) }\end{array}$ & $\begin{array}{c}\text { Total C } \\
\text { (percent) }\end{array}$ & Inorg. C & Org. C \\
(percent) & (percent) \\
\hline 364 & 29.76 & & \\
374 & 30.95 & & \\
Lake Minnetonka & & & \\
21.5 & 13.04 & 2.49 & 10.56 \\
31.5 & 14.25 & 1.93 & 12.32 \\
41.5 & 15.48 & 1.65 & 13.83 \\
51.5 & 14.66 & 0.98 & 13.68 \\
61.5 & 14.76 & 1.66 & 13.09 \\
71.5 & 12.06 & 1.22 & 10.83 \\
81.5 & 9.58 & 0.60 & 8.98 \\
91.5 & 11.03 & 0.67 & 10.36 \\
101.5 & 18.69 & 0.39 & 18.30 \\
111.5 & 20.63 & 0.35 & 20.28 \\
121.5 & 22.40 & 0.38 & 22.02 \\
131.5 & 22.55 & 0.31 & 22.25 \\
141.5 & 18.85 & 0.35 & 18.50 \\
151.5 & 18.99 & 0.34 & 18.65 \\
161.5 & 18.01 & 0.44 & 17.56 \\
171.5 & 17.53 & 0.42 & 17.11 \\
181.5 & 16.53 & 0.40 & 16.13 \\
201.5 & 17.23 & 0.81 & 16.41 \\
211.5 & 17.95 & 0.69 & 17.26 \\
221.5 & 19.12 & 0.72 & 18.40 \\
231.5 & 18.34 & 0.69 & 17.65 \\
241.5 & 19.84 & 0.70 & 19.14 \\
251.5 & 19.71 & 0.65 & 19.06 \\
261.5 & 19.89 & 0.65 & 19.25 \\
271.5 & 20.31 & 0.63 & 19.68 \\
281.5 & 19.34 & 0.53 & 18.80 \\
291.5 & 20.31 & 0.68 & 19.63 \\
301.5 & 23.30 & 0.65 & 22.65 \\
311.5 & 18.86 & 0.61 & 18.25 \\
321.5 & 19.00 & 0.81 & 18.19 \\
331.5 & 18.94 & 0.72 & 18.22 \\
341.5 & 14.89 & 1.93 & 12.96 \\
351.5 & 15.76 & 1.11 & 14.65 \\
361.5 & 15.21 & 1.04 & 14.17 \\
371.5 & 16.11 & 0.83 & 15.28 \\
381.5 & 13.74 & 1.45 & 12.29 \\
391.5 & 13.46 & 1.54 & 11.92 \\
401.5 & 13.25 & 2.34 & 10.91 \\
411.5 & 13.06 & 1.86 & 11.20
\end{tabular}

\begin{tabular}{cccc}
\hline $\begin{array}{c}\text { Depth } \\
\text { (centimeters) }\end{array}$ & $\begin{array}{c}\text { Total C } \\
\text { (percent) }\end{array}$ & $\begin{array}{c}\text { Inorg. C } \\
\text { (percent) }\end{array}$ & $\begin{array}{c}\text { Org. C } \\
\text { (percent) }\end{array}$ \\
\hline 421.5 & 12.39 & 2.01 & 10.38 \\
431.5 & 12.28 & 2.15 & 10.13 \\
441.5 & 11.50 & 2.67 & 8.83 \\
Lake Pepin & & & \\
(long core) & & & \\
11.5 & 4.45 & 1.14 & 3.31 \\
31.5 & 4.66 & 1.05 & 3.62 \\
51.5 & 4.40 & 0.69 & 3.71 \\
71.5 & 4.23 & 0.67 & 3.56 \\
91.5 & 3.90 & 0.37 & 3.53 \\
111.5 & 3.81 & 0.19 & 3.62 \\
131.5 & 3.72 & 0.41 & 3.31 \\
151.5 & 3.67 & 0.48 & 3.20 \\
171.5 & 3.68 & 0.99 & 2.69 \\
191.5 & 3.62 & 1.14 & 2.48 \\
211.5 & 3.44 & 0.86 & 2.58 \\
231.5 & 3.44 & 1.13 & 2.31 \\
251.5 & 3.44 & 1.09 & 2.35 \\
271.5 & 3.38 & 1.07 & 2.32 \\
286.5 & 3.35 & 1.03 & 2.32 \\
421.5 & 3.60 & 0.92 & 2.67 \\
441.5 & 3.75 & 0.93 & 2.83 \\
461.5 & 3.71 & 0.77 & 2.94 \\
481.5 & 3.50 & 0.91 & 2.60 \\
501.5 & 3.46 & 0.88 & 2.58 \\
521.5 & 3.62 & 0.87 & 2.76 \\
541.5 & 3.54 & 0.93 & 2.61 \\
558.5 & 3.84 & 0.79 & 3.05 \\
581.5 & 3.82 & 0.90 & 2.92 \\
601.5 & 3.86 & 0.84 & 3.02 \\
621.5 & 3.58 & 0.87 & 2.71 \\
641.5 & 3.73 & 0.90 & 2.82 \\
661.5 & 3.66 & 0.91 & 2.76 \\
681.5 & 3.78 & 1.01 & 2.76 \\
701.5 & 3.94 & 0.91 & 3.03 \\
721.5 & 3.79 & 0.60 & 3.19 \\
754.5 & 3.54 & 1.05 & 2.50 \\
771.5 & 3.15 & 0.64 & 2.51 \\
791.5 & 3.67 & 1.09 & 2.58 \\
811.5 & 3.88 & 0.92 & 2.96 \\
831.5 & 3.86 & 0.99 & 2.87 \\
& 3.66 & 0.93 & 2.73
\end{tabular}


Appendix 1. Results of carbon analyses.-Continued

\begin{tabular}{|c|c|c|c|c|c|c|c|}
\hline $\begin{array}{c}\text { Depth } \\
\text { (centimeters) }\end{array}$ & $\begin{array}{c}\text { Total C } \\
\text { (percent) }\end{array}$ & $\begin{array}{l}\text { Inorg. } \\
\text { percen }\end{array}$ & $\begin{array}{l}\text { Org. C } \\
\text { (percent) }\end{array}$ & $\begin{array}{c}\text { Depth } \\
\text { (centimeters) }\end{array}$ & $\begin{array}{c}\text { Total C } \\
\text { (percent) }\end{array}$ & $\begin{array}{l}\text { Inorg. C } \\
\text { (percent) }\end{array}$ & $\begin{array}{c}\text { Org. C } \\
\text { (percent) }\end{array}$ \\
\hline 871.5 & 4.42 & 1.46 & 2.96 & 439 & 9.34 & 4.82 & 4.52 \\
\hline 891.5 & 4.73 & 1.16 & 3.57 & 459 & 7.60 & 4.12 & 3.48 \\
\hline 911.5 & 5.28 & 1.30 & 3.97 & 459 & 7.62 & 4.16 & 3.46 \\
\hline 931.5 & 5.64 & 1.92 & 3.72 & 479 & 10.33 & 5.40 & 4.93 \\
\hline 951.5 & 5.41 & 2.13 & 3.28 & 498 & 11.07 & 5.45 & 5.62 \\
\hline 971.5 & 6.15 & 2.54 & 3.62 & 519 & 10.63 & 5.61 & 5.02 \\
\hline 991.5 & 5.85 & 2.66 & 3.19 & 539 & 8.03 & 4.36 & 3.67 \\
\hline 1011.5 & 6.36 & 2.65 & 3.71 & 569 & 10.47 & 4.71 & 5.76 \\
\hline 1031.5 & 6.88 & 3.54 & 3.34 & 619 & 10.65 & 5.60 & 5.05 \\
\hline 1051.5 & 4.36 & 1.79 & 2.57 & 658 & 9.06 & 4.48 & 4.58 \\
\hline 1071.5 & 5.68 & 2.86 & 2.82 & 699 & 9.37 & 4.78 & 4.59 \\
\hline 1091.5 & 7.38 & 4.51 & 2.87 & 739 & 10.66 & 5.07 & 5.59 \\
\hline 1111.5 & 7.20 & 4.70 & 2.50 & 739 & 10.89 & 5.06 & 5.83 \\
\hline 1131.5 & 5.94 & 3.56 & 2.39 & 779 & 9.75 & 4.73 & 5.02 \\
\hline 1151.5 & 6.58 & 3.91 & 2.67 & 819 & 10.08 & 5.47 & 4.61 \\
\hline 1171.5 & 5.92 & 3.29 & 2.63 & 839 & 8.82 & 4.60 & 4.22 \\
\hline 1191.5 & 8.77 & 5.49 & 3.27 & 869 & 10.23 & 4.46 & 5.77 \\
\hline Pickerel Lake & & & & 909 & 10.33 & 5.31 & 5.02 \\
\hline 1 & 10.01 & 4.12 & 5.89 & 949 & 9.27 & 4.78 & 4.49 \\
\hline 19 & 9.69 & 4.02 & 5.67 & 989 & 9.21 & 4.79 & 4.42 \\
\hline 39 & 8.39 & 4.04 & 4.35 & 989 & 9.31 & & \\
\hline 59 & 10.09 & 4.79 & 5.30 & 1039 & 10.56 & 4.98 & 5.58 \\
\hline 79 & 11.08 & 4.93 & 6.15 & 1079 & 10.24 & 4.84 & 5.40 \\
\hline 102 & 11.49 & 5.10 & 6.39 & 1120 & 9.31 & 4.17 & 5.14 \\
\hline 102 & 11.40 & 5.06 & 6.34 & 1160 & 9.36 & 4.73 & 4.63 \\
\hline 119 & 10.05 & 4.74 & 5.31 & 1189 & 7.72 & 3.63 & 4.09 \\
\hline 139 & 10.00 & 4.47 & 5.53 & 1210 & 7.71 & 4.21 & 3.50 \\
\hline 159 & 9.63 & 4.65 & 4.98 & 1230 & 8.82 & 4.19 & 4.63 \\
\hline 179 & 9.43 & 4.96 & 4.47 & 1250 & 8.71 & 4.52 & 4.19 \\
\hline 198 & 9.74 & 4.99 & 4.75 & 1270 & 8.43 & 4.31 & 4.12 \\
\hline 219 & 11.20 & 5.45 & 5.75 & 1290 & 8.35 & 4.04 & 4.31 \\
\hline 239 & 10.74 & 5.18 & 5.56 & 1310 & 7.15 & 4.04 & 3.11 \\
\hline 239 & 10.76 & 4.84 & 5.92 & 1335 & 4.69 & 2.98 & 1.71 \\
\hline 259 & 8.92 & 4.04 & 4.88 & 1342 & 5.68 & 3.63 & 2.05 \\
\hline 279 & 9.23 & 4.66 & 4.57 & 1360 & 6.73 & 4.33 & 2.40 \\
\hline 298 & 10.22 & 5.13 & 5.09 & 1390 & 7.53 & 5.02 & 2.51 \\
\hline 319 & 9.10 & 4.37 & 4.73 & 1390 & 7.56 & 5.08 & 2.48 \\
\hline 339 & 9.88 & 4.86 & 5.02 & 1407 & 6.52 & 4.10 & 2.42 \\
\hline 359 & 9.16 & 4.59 & 4.57 & 1423 & 5.22 & 3.32 & 1.90 \\
\hline 379 & 8.38 & 4.22 & 4.16 & 1430 & 8.09 & 6.19 & 1.90 \\
\hline 397 & 9.56 & 4.64 & 4.92 & 1450 & 9.18 & 6.66 & 2.52 \\
\hline 419 & 10.45 & 5.02 & 5.43 & 1460 & 9.42 & 7.04 & 2.38 \\
\hline
\end{tabular}


Appendix 1. Results of carbon analyses.-Continued

\begin{tabular}{|c|c|c|c|c|c|c|c|}
\hline $\begin{array}{c}\text { Depth } \\
\text { (centimeters) }\end{array}$ & $\begin{array}{r}\text { Total C } \\
\text { (percent) }\end{array}$ & $\begin{array}{l}\text { Inorg. } \\
\text { (percen } \\
\end{array}$ & $\begin{array}{l}\text { Org. C } \\
\text { percent) }\end{array}$ & $\begin{array}{c}\text { Depth } \\
\text { (centimeters) }\end{array}$ & $\begin{array}{c}\text { Total C } \\
\text { (percent) }\end{array}$ & $\begin{array}{l}\text { Inorg. C } \\
\text { (percent) }\end{array}$ & $\begin{array}{c}\text { Org. C } \\
\text { (percent) }\end{array}$ \\
\hline 1466 & 8.57 & 5.64 & 2.93 & 3.3 & 14.45 & 9.16 & 5.29 \\
\hline 1477 & 9.75 & 7.12 & 2.63 & 3.4 & 12.60 & 8.85 & 3.75 \\
\hline 1494 & 10.45 & 8.50 & 1.95 & 3.5 & 13.58 & 9.33 & 4.25 \\
\hline 1505 & 11.03 & 8.63 & 2.40 & 3.6 & 13.21 & 8.01 & 5.20 \\
\hline 1517 & 11.40 & 8.97 & 2.43 & 3.7 & 13.70 & 8.52 & 5.18 \\
\hline 1534 & 11.42 & 8.59 & 2.83 & 3.8 & 13.50 & 8.73 & 4.77 \\
\hline 1553 & 11.54 & 9.14 & 2.40 & 3.9 & 13.60 & 7.77 & 5.83 \\
\hline 1563 & 11.29 & 8.80 & 2.49 & 4 & 14.14 & 8.57 & 5.57 \\
\hline 1569 & 11.43 & 9.44 & 1.99 & 4.1 & 13.59 & 8.54 & 5.04 \\
\hline 1576 & 11.32 & 8.58 & 2.74 & 4.2 & 15.91 & 7.20 & 8.71 \\
\hline 1583 & 11.26 & 9.22 & 2.04 & 4.3 & 14.83 & 4.75 & 10.08 \\
\hline 1601 & 9.07 & 4.92 & 4.15 & 4.4 & 13.93 & 8.09 & 5.84 \\
\hline 1622 & 7.41 & 4.58 & 2.83 & 4.5 & 12.12 & 8.63 & 3.49 \\
\hline 1637 & 5.01 & 2.95 & 2.06 & 4.6 & 11.91 & 8.71 & 3.20 \\
\hline 1642 & 5.20 & 1.84 & 3.36 & 4.7 & 13.43 & 6.40 & 7.04 \\
\hline 1681 & 4.25 & 2.67 & 1.58 & 4.8 & 15.37 & 6.18 & 9.19 \\
\hline 1692 & 2.72 & 1.31 & 1.41 & 4.9 & 13.58 & 8.31 & 5.27 \\
\hline 1695 & 8.68 & 3.94 & 4.74 & 5 & 14.56 & 6.37 & 8.19 \\
\hline Blacktail Pond & & & & 5.1 & 15.05 & 6.88 & 8.17 \\
\hline 1 & 14.58 & 7.55 & 7.03 & 5.2 & 14.55 & 7.27 & 7.27 \\
\hline 1.1 & 13.33 & 8.36 & 4.97 & 5.3 & 13.17 & 7.85 & 5.32 \\
\hline 1.2 & 13.10 & 9.04 & 4.06 & 5.4 & 23.09 & 3.65 & 19.44 \\
\hline 1.3 & 13.02 & 9.12 & 3.90 & 5.43 & 13.91 & 8.72 & 5.19 \\
\hline 1.4 & 13.06 & 9.30 & 3.76 & 5.5 & 13.39 & 8.56 & 4.82 \\
\hline 1.5 & 14.00 & 8.50 & 5.50 & 5.6 & 14.17 & 8.07 & 6.11 \\
\hline 1.6 & 13.31 & 9.09 & 4.21 & 5.8 & 13.40 & 8.58 & 4.82 \\
\hline 1.7 & 12.85 & 9.48 & 3.37 & 6 & 12.43 & 5.18 & 7.24 \\
\hline 1.8 & 13.26 & 8.84 & 4.42 & 6.08 & 14.79 & 2.85 & 11.94 \\
\hline 1.9 & 13.45 & 8.96 & 4.49 & 6.18 & 12.89 & 3.94 & 8.96 \\
\hline 2 & 14.00 & 9.10 & 4.90 & 6.28 & 18.00 & 5.65 & 12.35 \\
\hline 2.1 & 13.80 & 8.60 & 5.20 & 6.38 & 14.83 & 8.32 & 6.51 \\
\hline 2.2 & 12.93 & 9.36 & 3.57 & 6.48 & 13.67 & 9.60 & 4.07 \\
\hline 2.3 & 13.80 & 9.80 & 4.00 & 6.58 & 14.81 & 8.90 & 5.90 \\
\hline 2.4 & 13.03 & 10.28 & 2.75 & 6.68 & 14.23 & 8.49 & 5.74 \\
\hline 2.5 & 12.97 & 9.42 & 3.55 & 6.78 & 13.57 & 7.99 & 5.58 \\
\hline 2.6 & 12.79 & 9.71 & 3.08 & 6.9 & 14.04 & 8.12 & 5.92 \\
\hline 2.7 & 12.84 & 9.54 & 3.30 & 7 & 9.60 & 6.20 & 3.40 \\
\hline 2.8 & 13.24 & 9.05 & 4.19 & 7.1 & 2.96 & 1.58 & 1.38 \\
\hline 2.9 & 13.78 & 9.76 & 4.02 & 7.2 & 1.56 & 0.31 & 1.25 \\
\hline 3 & 13.00 & 9.79 & 3.22 & 7.3 & 1.66 & 0.18 & 1.48 \\
\hline 3.1 & 13.48 & 9.73 & 3.74 & 7.4 & 1.91 & 0.80 & 1.11 \\
\hline 3.2 & 13.26 & 9.30 & 3.96 & 7.5 & 0.67 & 0.21 & 0.46 \\
\hline
\end{tabular}


Appendix 1. Results of carbon analyses.-Continued

\begin{tabular}{|c|c|c|c|c|c|c|c|}
\hline $\begin{array}{c}\text { Depth } \\
\text { (centimeters) }\end{array}$ & $\begin{array}{c}\text { Total C } \\
\text { (percent) }\end{array}$ & $\begin{array}{l}\text { Inorg. } \\
\text { percen }\end{array}$ & $\begin{array}{l}\text { Org. } \mathrm{C} \\
\text { percent) }\end{array}$ & $\begin{array}{c}\text { Depth } \\
\text { (centimeters) }\end{array}$ & $\begin{array}{c}\text { Total C } \\
\text { (percent) }\end{array}$ & $\begin{array}{l}\text { Inorg. C } \\
\text { (percent) }\end{array}$ & $\begin{array}{c}\text { Org. C } \\
\text { (percent) }\end{array}$ \\
\hline 7.6 & 0.58 & 0.31 & 0.27 & 4.25 & 13.67 & 3.62 & 10.05 \\
\hline 7.7 & 0.51 & 0.29 & 0.23 & 4.35 & 8.86 & 2.18 & 6.68 \\
\hline \multicolumn{4}{|l|}{ Slough Creek Pond } & 4.45 & 12.91 & 3.70 & 9.21 \\
\hline 0.16 & 23.84 & 3.14 & 20.70 & 4.55 & 14.17 & 1.72 & 12.45 \\
\hline 0.24 & 19.99 & 4.02 & 15.97 & Trail Lake & & & \\
\hline 0.34 & 19.07 & 4.11 & 14.96 & 1 & 15.20 & & \\
\hline 0.44 & 18.08 & 3.08 & 15.00 & 9 & 13.30 & & \\
\hline 0.54 & 19.04 & 3.72 & 15.32 & 19 & 10.80 & & \\
\hline 0.64 & 22.08 & 3.48 & 18.60 & 29 & 11.20 & & \\
\hline 0.74 & 21.99 & 2.30 & 19.69 & 39 & 9.40 & & \\
\hline 0.84 & 20.38 & 3.49 & 16.89 & 49 & 9.30 & & \\
\hline 0.91 & 22.01 & 2.98 & 19.03 & 59 & 11.70 & & \\
\hline 1.01 & 21.30 & 1.68 & 19.62 & 69 & 9.20 & & \\
\hline 1.11 & 18.06 & 3.22 & 14.84 & 79 & 10.80 & & \\
\hline 1.21 & 20.10 & 4.54 & 15.56 & 89 & 12.20 & & \\
\hline 1.31 & 14.99 & 4.86 & 10.13 & 99 & 10.30 & & \\
\hline 1.41 & 20.11 & 3.89 & 16.22 & 109 & 10.00 & & \\
\hline 1.45 & 18.69 & 3.14 & 15.55 & 119 & 8.80 & & \\
\hline 1.51 & 16.49 & 4.27 & 12.22 & 129 & 7.50 & & \\
\hline 1.74 & 18.48 & 2.17 & 16.31 & 139 & 10.20 & & \\
\hline 1.84 & 18.38 & 1.46 & 16.92 & 149 & 9.20 & & \\
\hline 1.94 & 15.99 & 3.37 & 12.62 & 159 & 9.80 & & \\
\hline 2.04 & 15.84 & 3.04 & 12.80 & 169 & 10.80 & & \\
\hline 2.14 & 15.52 & 3.62 & 11.90 & 179 & 12.00 & & \\
\hline 2.24 & 13.86 & 3.09 & 10.77 & 189 & 10.00 & & \\
\hline 2.34 & 14.17 & 4.61 & 9.56 & 199 & 7.20 & & \\
\hline 2.55 & 16.26 & 4.55 & 11.71 & 209 & 6.10 & & \\
\hline 2.65 & 26.87 & 5.62 & 21.25 & 219 & 6.00 & & \\
\hline 2.75 & 20.95 & 4.70 & 16.25 & 229 & 5.60 & & \\
\hline 2.85 & 19.56 & 6.18 & 13.38 & 239 & 9.60 & & \\
\hline 2.95 & 22.56 & 4.46 & 18.10 & 249 & 8.00 & & \\
\hline 3.05 & 19.41 & 5.20 & 14.21 & 259 & 7.30 & & \\
\hline 3.13 & 17.84 & 4.39 & 13.45 & 269 & 5.30 & & \\
\hline 3.4 & 18.00 & 4.82 & 13.18 & 279 & 6.30 & & \\
\hline 3.45 & 16.74 & 4.04 & 12.70 & 289 & 8.00 & & \\
\hline 3.55 & 17.10 & 4.54 & 12.56 & 299 & 6.40 & & \\
\hline 3.65 & 16.91 & 4.11 & 12.80 & 319 & 5.50 & & \\
\hline 3.75 & 15.49 & 3.45 & 12.04 & 329 & 6.00 & & \\
\hline 3.85 & 12.64 & 3.78 & 8.86 & 339 & 4.20 & & \\
\hline 3.95 & 18.01 & 3.67 & 14.34 & 349 & 4.90 & & \\
\hline 4.05 & 16.46 & 3.45 & 13.01 & 359 & 7.90 & & \\
\hline 4.11 & 15.24 & 3.82 & 11.42 & 369 & 5.10 & & \\
\hline
\end{tabular}


Appendix 1. Results of carbon analyses.-Continued

\begin{tabular}{|c|c|c|c|}
\hline $\begin{array}{c}\text { Depth } \\
\text { (centimeters) }\end{array}$ & $\begin{array}{c}\text { Total C Inorg. C Org. C } \\
\text { (percent) (percent) (percent) }\end{array}$ & $\begin{array}{c}\text { Depth } \\
\text { (centimeters) } \\
\end{array}$ & $\begin{array}{c}\text { Total C Inorg. C Org. C } \\
\text { (percent) (percent) (percent) }\end{array}$ \\
\hline 379 & 8.80 & 789 & 5.30 \\
\hline 389 & 9.50 & 799 & 8.60 \\
\hline 399 & 10.40 & 809 & 8.00 \\
\hline 409 & 9.10 & 819 & 7.50 \\
\hline 419 & 8.20 & 829 & 7.10 \\
\hline 429 & 9.00 & 839 & 7.10 \\
\hline 439 & 9.90 & 849 & 7.20 \\
\hline 449 & 11.10 & 859 & 6.40 \\
\hline 459 & 9.60 & 869 & 8.80 \\
\hline 469 & 8.70 & 869 & 8.60 \\
\hline 479 & 7.90 & 879 & 9.30 \\
\hline 489 & 11.70 & 889 & 6.50 \\
\hline 499 & 5.10 & 899 & 5.50 \\
\hline 509 & 5.40 & 909 & 6.50 \\
\hline 529 & 8.90 & 919 & 4.50 \\
\hline 539 & 8.50 & 929 & 3.40 \\
\hline 549 & 6.80 & 939 & 2.20 \\
\hline 559 & 10.00 & 949 & 2.80 \\
\hline 569 & 6.10 & 959 & 0.90 \\
\hline 579 & 6.80 & 969 & 0.60 \\
\hline 589 & 9.10 & 979 & 0.70 \\
\hline 599 & 10.50 & 989 & 0.70 \\
\hline 609 & 12.20 & 999 & 0.70 \\
\hline 619 & 9.70 & Cygnet Lake & \\
\hline 629 & 9.40 & 0 & 12.57 \\
\hline 639 & 10.50 & 10 & 13.94 \\
\hline 649 & 10.10 & 24 & 12.84 \\
\hline 659 & 10.50 & 30 & 10.14 \\
\hline 669 & 9.80 & 40 & 9.15 \\
\hline 679 & 9.20 & 50 & 12.48 \\
\hline 689 & 5.50 & 60 & 8.17 \\
\hline 699 & 9.20 & 70 & 8.63 \\
\hline 709 & 5.30 & 80 & 10.32 \\
\hline 719 & 5.40 & 90 & 10.54 \\
\hline 729 & 4.30 & 100 & 10.02 \\
\hline 739 & 5.00 & 110 & 10.48 \\
\hline 749 & 7.50 & 120 & 9.43 \\
\hline 749 & 7.30 & 130 & 10.14 \\
\hline 759 & 9.60 & 140 & 10.95 \\
\hline 769 & 9.00 & 150 & 10.09 \\
\hline 779 & 8.10 & 154 & 10.38 \\
\hline 789 & 5.40 & 159 & 10.58 \\
\hline
\end{tabular}


Appendix 1. Results of carbon analyses.-Continued

\begin{tabular}{|c|c|}
\hline $\begin{array}{c}\text { Depth } \\
\text { (centimeters) }\end{array}$ & $\begin{array}{c}\text { Total C Inorg. C Org. C } \\
\text { (percent) } \\
\text { (percent) (percent) }\end{array}$ \\
\hline 170 & 9.36 \\
\hline 180 & 8.64 \\
\hline 190 & 9.15 \\
\hline 202 & 10.84 \\
\hline 210 & 10.27 \\
\hline 220 & 9.07 \\
\hline 230 & 9.94 \\
\hline 241 & 13.10 \\
\hline 252 & 10.28 \\
\hline 261 & 10.70 \\
\hline 270 & 10.80 \\
\hline 283 & 12.52 \\
\hline 292 & 14.08 \\
\hline 315 & 13.57 \\
\hline 322 & 12.99 \\
\hline 330 & 3.08 \\
\hline 331 & 13.91 \\
\hline 340 & 12.42 \\
\hline 367 & 12.91 \\
\hline 371 & 12.31 \\
\hline 382 & 13.47 \\
\hline 391 & 12.68 \\
\hline 397 & 13.00 \\
\hline 400 & 11.36 \\
\hline 410 & 13.70 \\
\hline 420 & 14.11 \\
\hline 430 & 14.17 \\
\hline 440 & 15.60 \\
\hline 450 & 17.63 \\
\hline 460 & 16.18 \\
\hline 470 & 15.65 \\
\hline 480 & 16.44 \\
\hline 490 & 13.85 \\
\hline 504 & 14.64 \\
\hline 510 & 11.36 \\
\hline 526 & 3.08 \\
\hline 539 & 2.62 \\
\hline 550 & 2.65 \\
\hline 560 & 3.75 \\
\hline 570 & 2.84 \\
\hline 580 & 1.80 \\
\hline 590 & 2.05 \\
\hline
\end{tabular}

\begin{tabular}{cc}
\hline $\begin{array}{c}\text { Depth } \\
\text { (centimeters) }\end{array}$ & $\begin{array}{c}\text { Total C Inorg. C } \\
\text { (percent) } \text { (percent) } \text { (percent) }\end{array}$ \\
\hline 600 & 4.01 \\
610 & 1.29 \\
620 & 0.75 \\
630 & 0.74 \\
640 & 0.61 \\
649 & 0.49 \\
660 & 0.26 \\
670 & 0.62 \\
680 & 0.40 \\
690 & 0.45 \\
\hline
\end{tabular}


Appendix 2. Results of Rock-Eval pyrolysis.

\begin{tabular}{ccccccc}
\hline Depth & Org. C & S1 & S2 & S3 & HI & OI \\
& & (milligram & (milligram & (milligram & (milligram & (milligram \\
(centimeters) & (percent) & per gram) & per gram) & per gram) & per gram) & per gram) \\
\hline
\end{tabular}

Spectacle Lake

$\begin{array}{ccccccc}2 & 27.9 & 6.6 & 216.3 & 34.0 & 774 & 121 \\ 62 & 59.2 & 10.2 & 549.2 & 50.0 & 928 & 84 \\ 153 & 44.2 & 8.0 & 401.9 & 40.8 & 909 & 92 \\ 183 & 49.1 & 5.7 & 440.8 & 43.0 & 898 & 87 \\ 334 & 50.6 & 6.5 & 458.6 & 42.3 & 907 & 83 \\ 374 & 46.9 & 6.9 & 430.3 & 40.4 & 917 & 86\end{array}$

Lake Minnetonka

$\begin{array}{ccccccc}20-23 & 8.1 & 0.8 & 42.9 & 25.3 & 532 & 313 \\ 30-33 & 10.3 & 0.9 & 59.2 & 30.6 & 573 & 296 \\ 40-43 & 11.8 & 0.8 & 64.5 & 33.3 & 548 & 283 \\ 50-53 & 12.2 & 0.9 & 74.3 & 31.9 & 609 & 261 \\ 60-63 & 12.6 & 0.9 & 76.0 & 31.0 & 601 & 245 \\ 70-73 & 8.1 & 0.5 & 35.6 & 28.1 & 441 & 349 \\ 80-83 & 2.5 & 0.2 & 10.3 & 15.0 & 414 & 606 \\ 90-93 & 7.0 & 0.6 & 36.2 & 25.2 & 518 & 361 \\ 100-103 & 19.7 & 1.3 & 125.1 & 38.0 & 634 & 192 \\ 110-113 & 21.7 & 1.3 & 143.2 & 39.0 & 658 & 179 \\ 120-123 & 25.3 & 1.6 & 176.2 & 40.4 & 695 & 159 \\ 130-133 & 25.7 & 1.4 & 172.9 & 39.0 & 672 & 151 \\ 140-143 & 25.3 & 1.7 & 175.0 & 37.4 & 691 & 147 \\ 150-153 & 21.4 & 1.2 & 144.4 & 33.6 & 673 & 156 \\ 160-163 & 20.4 & 1.1 & 136.4 & 31.7 & 668 & 155 \\ 170-173 & 19.5 & 1.1 & 128.1 & 33.1 & 655 & 169 \\ 180-183 & 14.2 & 0.5 & 73.0 & 37.2 & 515 & 262 \\ 200-203 & 17.6 & 1.0 & 115.9 & 36.2 & 659 & 205 \\ 210-213 & 18.1 & 0.9 & 112.5 & 36.0 & 620 & 198 \\ 220-223 & 19.8 & 1.2 & 131.7 & 43.4 & 665 & 219 \\ 230-233 & 17.4 & 1.4 & 106.0 & 40.2 & 608 & 230 \\ 240-243 & 21.9 & 2.0 & 161.3 & 36.9 & 736 & 168 \\ 250-253 & 22.6 & 2.0 & 163.8 & 34.7 & 723 & 153 \\ 260-263 & 22.9 & 1.5 & 156.9 & 36.1 & 685 & 157 \\ 270-273 & 22.0 & 2.3 & 152.5 & 38.4 & 691 & 174 \\ 280-283 & 20.6 & 2.9 & 139.0 & 43.1 & 675 & 209 \\ 290-293 & 18.9 & 0.8 & 122.6 & 43.0 & 649 & 227 \\ 300-303 & 22.7 & 1.8 & 165.6 & 41.0 & 731 & 180 \\ 310-313 & 21.1 & 1.4 & 152.1 & 37.0 & 721 & 175 \\ 320-323 & 20.5 & 1.2 & 147.3 & 33.2 & 719 & 162 \\ 330-333 & 20.6 & 1.9 & 144.3 & 35.2 & 701 & 171 \\ 340-343 & 12.7 & 1.0 & 81.1 & 27.8 & 636 & 218 \\ 350-353 & 15.3 & 1.3 & 104.9 & 32.1 & 687 & 210 \\ 360-363 & 14.4 & 1.4 & 90.4 & 30.1 & 629 & 209\end{array}$


Appendix 2. Results of Rock-Eval pyrolysis.-Continued

\begin{tabular}{|c|c|c|c|c|c|c|}
\hline Depth & Org. C & S1 & S2 & S3 & HI & OI \\
\hline (centimeters) & (percent) & $\begin{array}{l}\text { (milligram } \\
\text { per gram) }\end{array}$ & $\begin{array}{c}\text { (milligram } \\
\text { per gram) }\end{array}$ & $\begin{array}{l}\text { (milligram } \\
\text { per gram) }\end{array}$ & $\begin{array}{l}\text { (milligram } \\
\text { per gram) }\end{array}$ & $\begin{array}{l}\text { (milligi } \\
\text { per gra }\end{array}$ \\
\hline $370-373$ & 16.0 & 1.1 & 104.1 & 31.1 & 651 & 194 \\
\hline $380-383$ & 11.5 & 0.6 & 70.8 & 26.9 & 617 & 234 \\
\hline $390-393$ & 11.0 & 0.7 & 69.8 & 26.9 & 632 & 243 \\
\hline $400-403$ & 9.4 & 0.5 & 56.3 & 25.5 & 599 & 271 \\
\hline $410-413$ & 10.2 & 0.6 & 57.6 & 26.1 & 566 & 256 \\
\hline $420-423$ & 8.5 & 0.6 & 46.9 & 25.2 & 552 & 297 \\
\hline $430-433$ & 8.4 & 0.5 & 45.1 & 25.4 & 538 & 303 \\
\hline $440-443$ & 6.6 & 0.3 & 28.0 & 24.7 & 423 & 373 \\
\hline \multicolumn{7}{|c|}{ Lake Pepin, core D2 } \\
\hline $0-20$ & 3.3 & 0.1 & 6.8 & 5.1 & 250 & 186 \\
\hline $40-44$ & 9.1 & 0.1 & 5.1 & 5.2 & 171 & 175 \\
\hline $60-64$ & 9.0 & 0.1 & 5.6 & 4.7 & 186 & 158 \\
\hline $76-80$ & 9.0 & 0.1 & 4.3 & 5.2 & 150 & 182 \\
\hline $92-96$ & 9.1 & 0.1 & 4.9 & 5.4 & 169 & 186 \\
\hline $116-120$ & 8.2 & 0.1 & 2.9 & 4.8 & 119 & 197 \\
\hline $140-144$ & 6.2 & 0.0 & 2.2 & 3.7 & 120 & 206 \\
\hline $164-168$ & 5.9 & 0.0 & 1.9 & 2.9 & 118 & 180 \\
\hline $196-200$ & 6.1 & 0.0 & 1.6 & 3.2 & 101 & 201 \\
\hline $228-232$ & 6.2 & 0.0 & 1.6 & 3.1 & 98 & 193 \\
\hline $256-260$ & 6.0 & 0.0 & 1.8 & 2.9 & 107 & 179 \\
\hline
\end{tabular}

Elk Lake (Dean and Stuiver, 1993)

$\begin{array}{ccccccc}50 & 7.0 & 1.2 & 13.1 & 15.9 & 188 & 228 \\ 100 & 6.7 & 0.1 & 18.6 & 18.0 & 277 & 268 \\ 220 & 5.7 & 1.6 & 12.4 & 20.4 & 218 & 358 \\ 240 & 6.0 & 0.8 & 12.0 & 18.1 & 201 & 304 \\ 400 & 5.7 & 1.0 & 9.8 & 22.0 & 174 & 384 \\ 410 & 5.7 & 1.2 & 10.9 & 18.2 & 193 & 321 \\ 490 & 4.6 & 1.1 & 7.9 & 13.3 & 170 & 287 \\ 570 & 4.4 & 0.9 & 9.0 & 16.0 & 205 & 363 \\ 600 & 4.3 & 0.9 & 7.7 & 14.2 & 178 & 331 \\ 610 & 4.0 & 1.0 & 9.7 & 12.9 & 242 & 322 \\ 700 & 3.7 & 1.6 & 8.7 & 9.4 & 235 & 253 \\ 710 & 3.9 & 0.0 & 5.5 & 13.2 & 139 & 335 \\ 1000 & 2.6 & 0.0 & 3.8 & 5.0 & 149 & 195 \\ 1010 & 2.1 & 0.6 & 4.6 & 3.6 & 223 & 176 \\ 1080 & 2.8 & 0.1 & 3.9 & 4.0 & 140 & 143 \\ 1220 & 2.8 & 1.0 & 7.3 & 4.2 & 257 & 150 \\ 1320 & 2.2 & 1.2 & 5.5 & 3.1 & 249 & 137 \\ 1330 & 2.4 & 1.2 & 7.2 & 3.2 & 298 & 134 \\ 1520 & 2.0 & 0.5 & 4.9 & 3.3 & 241 & 161 \\ 1680 & 2.5 & 1.0 & 6.6 & 3.4 & 268 & 136\end{array}$


Appendix 2. Results of Rock-Eval pyrolysis.-Continued

\begin{tabular}{|c|c|c|c|c|c|c|}
\hline Depth & Org. C & & & S3 & HI & OI \\
\hline (centimeters) & (percent) & $\begin{array}{l}\text { (milligram } \\
\text { per gram) }\end{array}$ & $\begin{array}{l}\text { (milligram } \\
\text { per gram) }\end{array}$ & $\begin{array}{l}\text { (milligram } \\
\text { per gram) }\end{array}$ & $\begin{array}{l}\text { (milligram } \\
\text { per gram) }\end{array}$ & $\begin{array}{l}\text { (milligr } \\
\text { per gra }\end{array}$ \\
\hline 1700 & 2.4 & 0.5 & 5.3 & 2.8 & 219 & 116 \\
\hline 1820 & 2.2 & 0.5 & 4.5 & 4.1 & 204 & 185 \\
\hline 1920 & 2.8 & 0.8 & 4.5 & 6.1 & 162 & 221 \\
\hline 2000 & 3.5 & 1.8 & 6.2 & 10.0 & 180 & 290 \\
\hline \multicolumn{7}{|l|}{ Trail Lake } \\
\hline 1 & 10.7 & 5.1 & 67.0 & 18.1 & 628 & 169 \\
\hline 19 & 17.0 & 8.9 & 119.1 & 23.4 & 701 & 137 \\
\hline 39 & 8.4 & 2.6 & 48.2 & 19.0 & 573 & 226 \\
\hline 59 & 11.2 & 3.8 & 75.1 & 20.9 & 670 & 186 \\
\hline 79 & 10.6 & 3.6 & 62.4 & 18.7 & 588 & 176 \\
\hline 99 & 9.9 & 3.0 & 61.2 & 18.4 & 617 & 185 \\
\hline 119 & 7.3 & 2.0 & 38.7 & 15.7 & 531 & 215 \\
\hline 139 & 9.0 & 3.0 & 53.2 & 18.0 & 593 & 201 \\
\hline 159 & 8.7 & 2.3 & 52.0 & 18.0 & 595 & 206 \\
\hline 179 & 12.1 & 3.1 & 74.7 & 18.4 & 618 & 152 \\
\hline 199 & 6.4 & 1.7 & 31.0 & 13.8 & 487 & 217 \\
\hline 219 & 5.4 & 1.8 & 29.2 & 12.6 & 540 & 232 \\
\hline 239 & 8.7 & 2.5 & 51.6 & 16.3 & 589 & 186 \\
\hline 259 & 6.4 & 2.1 & 35.1 & 13.3 & 551 & 208 \\
\hline 279 & 5.2 & 2.7 & 27.5 & 11.6 & 533 & 224 \\
\hline 299 & 5.1 & 2.4 & 27.6 & 12.3 & 542 & 242 \\
\hline 319 & 4.2 & 1.7 & 19.6 & 9.3 & 470 & 223 \\
\hline 339 & 2.9 & 1.4 & 11.7 & 7.4 & 400 & 255 \\
\hline 359 & 7.1 & 2.1 & 36.4 & 12.4 & 511 & 174 \\
\hline 379 & 8.2 & 2.8 & 41.7 & 11.5 & 512 & 141 \\
\hline 399 & 9.9 & 2.3 & 47.0 & 14.4 & 475 & 145 \\
\hline 419 & 6.9 & 2.4 & 27.7 & 11.6 & 399 & 166 \\
\hline 439 & 9.1 & 2.4 & 43.0 & 13.6 & 472 & 149 \\
\hline 459 & 8.8 & 2.1 & 42.2 & 13.5 & 481 & 153 \\
\hline 479 & 6.6 & 2.7 & 25.2 & 10.9 & 384 & 165 \\
\hline 499 & 6.2 & 3.0 & 30.2 & 11.0 & 484 & 175 \\
\hline 539 & 7.9 & 2.0 & 35.6 & 13.5 & 451 & 171 \\
\hline 559 & 9.6 & 1.1 & 45.8 & 15.2 & 478 & 159 \\
\hline 579 & 5.2 & 0.7 & 14.5 & 10.4 & 280 & 200 \\
\hline 599 & 10.4 & 1.3 & 53.2 & 14.0 & 512 & 134 \\
\hline 619 & 9.6 & 1.0 & 50.6 & 13.5 & 526 & 140 \\
\hline 639 & 9.5 & 1.0 & 44.8 & 15.1 & 474 & 160 \\
\hline 659 & 10.1 & 1.5 & 47.7 & 15.5 & 473 & 153 \\
\hline 679 & 8.9 & 2.3 & 48.8 & 12.5 & 548 & 141 \\
\hline 699 & 8.1 & 2.2 & 39.7 & 13.5 & 492 & 167 \\
\hline 719 & 4.5 & 1.5 & 22.4 & 9.7 & 497 & 216 \\
\hline 739 & 3.9 & 1.6 & 17.3 & 7.8 & 442 & 201 \\
\hline 759 & 8.4 & 1.7 & 40.3 & 13.1 & 480 & 156 \\
\hline
\end{tabular}


Appendix 2. Results of Rock-Eval pyrolysis.-Continued

\begin{tabular}{|c|c|c|c|c|c|c|}
\hline Depth & Org. C & S1 & S2 & S3 & HI & OI \\
\hline (centimeters) & (percent) & $\begin{array}{l}\text { (milligram } \\
\text { per gram) }\end{array}$ & $\begin{array}{l}\text { (milligram } \\
\text { per gram) }\end{array}$ & $\begin{array}{l}\text { (milligram } \\
\text { per gram) }\end{array}$ & $\begin{array}{l}\text { (milligram } \\
\text { per gram) }\end{array}$ & $\begin{array}{l}\text { (milligra } \\
\text { per gran }\end{array}$ \\
\hline 779 & 7.8 & 2.1 & 43.2 & 11.3 & 553 & 144 \\
\hline 799 & 7.7 & 0.8 & 35.9 & 12.1 & 464 & 156 \\
\hline 819 & 6.4 & 0.9 & 33.3 & 11.5 & 522 & 180 \\
\hline 839 & 6.6 & 0.9 & 33.3 & 11.7 & 505 & 177 \\
\hline 859 & 5.8 & 1.0 & 28.8 & 10.5 & 499 & 182 \\
\hline 879 & 9.1 & 1.8 & 54.8 & 14.2 & 601 & 155 \\
\hline 899 & 4.9 & 1.6 & 26.5 & 8.9 & 542 & 181 \\
\hline 919 & 3.5 & 1.0 & 13.3 & 6.6 & 380 & 189 \\
\hline 939 & 1.7 & 0.5 & 4.3 & 2.3 & 254 & 134 \\
\hline 959 & 0.5 & 0.4 & 1.5 & 0.9 & 282 & 163 \\
\hline 979 & 0.4 & 0.2 & 1.1 & 0.8 & 302 & 210 \\
\hline 999 & 0.4 & 0.2 & 0.8 & 0.7 & 186 & 161 \\
\hline Slough Creek Ponc & & & & & & \\
\hline 16 & 20.7 & 2.0 & 138.2 & 37.2 & 654 & 175 \\
\hline 24 & 16.0 & 0.5 & 83.2 & 36.2 & 553 & 240 \\
\hline 34 & 15.0 & 0.6 & 82.0 & 33.3 & 602 & 244 \\
\hline 44 & 15.0 & 0.9 & 96.2 & 34.0 & 635 & 224 \\
\hline 54 & 15.3 & 1.3 & 116.7 & 33.7 & 724 & 208 \\
\hline 64 & 18.6 & 1.0 & 112.3 & 37.0 & 593 & 195 \\
\hline 74 & 19.7 & 1.0 & 117.2 & 36.4 & 571 & 177 \\
\hline 84 & 16.9 & 0.7 & 81.4 & 37.0 & 514 & 234 \\
\hline 91 & 19.0 & 1.2 & 130.8 & 38.0 & 646 & 187 \\
\hline 101 & 19.6 & 2.0 & 150.5 & 35.6 & 672 & 159 \\
\hline 111 & 14.8 & 1.1 & 95.0 & 30.2 & 637 & 202 \\
\hline 121 & 15.6 & 0.9 & 84.3 & 32.9 & 581 & 226 \\
\hline 131 & 10.1 & 0.3 & 49.8 & 27.6 & 541 & 300 \\
\hline 141 & 16.2 & 0.7 & 95.6 & 34.7 & 584 & 211 \\
\hline 145 & 15.6 & 1.5 & 105.3 & 32.9 & 674 & 211 \\
\hline 151 & 12.2 & 0.7 & 89.1 & 29.8 & 695 & 232 \\
\hline 174 & 16.3 & 0.6 & 94.0 & 34.1 & 609 & 221 \\
\hline 184 & 16.9 & 0.9 & 119.2 & 32.6 & 677 & 185 \\
\hline 194 & 12.6 & 0.5 & 68.9 & 29.3 & 624 & 265 \\
\hline 204 & 12.8 & 0.8 & 90.2 & 30.3 & 727 & 244 \\
\hline 214 & 11.9 & 0.8 & 88.6 & 28.5 & 758 & 243 \\
\hline 224 & 10.8 & 0.6 & 77.2 & 27.8 & 766 & 275 \\
\hline 234 & 9.6 & 0.5 & 59.0 & 26.8 & 738 & 335 \\
\hline 255 & 11.7 & 1.3 & 74.2 & 27.0 & 786 & 286 \\
\hline 265 & 21.3 & 1.3 & 74.2 & 27.0 & 786 & 286 \\
\hline 275 & 16.3 & 2.3 & 91.7 & 33.7 & 780 & 286 \\
\hline 285 & 13.4 & 1.8 & 78.6 & 26.8 & 787 & 268 \\
\hline 295 & 18.1 & 2.4 & 146.6 & 26.3 & 896 & 160 \\
\hline 305 & 14.2 & 2.4 & 103.8 & 19.4 & 898 & 168 \\
\hline 313 & 13.5 & 2.6 & 94.8 & 21.5 & 864 & 195 \\
\hline
\end{tabular}


Appendix 2. Results of Rock-Eval pyrolysis.-Continued

\begin{tabular}{ccccccc}
\hline Depth & Org. C & $\begin{array}{c}\text { S1 } \\
\text { (milligram }\end{array}$ & $\begin{array}{c}\text { S2 } \\
\text { (milligram }\end{array}$ & $\begin{array}{c}\text { S3 } \\
\text { (milligram }\end{array}$ & $\begin{array}{c}\text { HI } \\
\text { (milligram }\end{array}$ & $\begin{array}{c}\text { OI } \\
\text { (milligram }\end{array}$ \\
\hline 340 & 13.2 & 2.7 & 77.9 & 21.1 & 757 & 204 \\
pentimeters) & (percent) & per gram) & per gram) & pram & per gram) & per gram) \\
345 & 12.7 & 4.4 & 93.7 & 21.8 & 849 & 197 \\
355 & 12.6 & 3.4 & 74.0 & 18.7 & 795 & 201 \\
365 & 12.8 & 2.9 & 94.5 & 20.2 & 821 & 175 \\
375 & 12.0 & 2.5 & 72.0 & 19.2 & 732 & 195 \\
385 & 8.9 & 1.0 & 25.7 & 11.7 & 718 & 327 \\
395 & 14.3 & 3.5 & 91.0 & 23.6 & 739 & 192 \\
405 & 13.0 & 2.9 & 87.5 & 20.7 & 774 & 183 \\
411 & 11.4 & 2.7 & 72.5 & 19.7 & 799 & 217 \\
425 & 10.1 & 1.5 & 56.8 & 17.2 & 776 & 235 \\
435 & 6.7 & 1.6 & 39.9 & 18.3 & 658 & 301 \\
445 & 9.2 & 1.7 & 50.1 & 21.4 & 782 & 334 \\
455 & 12.5 & 2.0 & 80.1 & 24.4 & 779 & 237 \\
463 & 8.6 & 2.3 & 52.2 & 20.4 & 682 & 266 \\
475 & 6.7 & 1.6 & 35.4 & 19.7 & 616 & 342 \\
485 & 1.1 & 0.5 & 1.3 & 0.1 & 928 & 85 \\
495 & 7.5 & 1.0 & 27.6 & 15.8 & 726 & 415 \\
\hline
\end{tabular}


Appendix 3. Results of carbon-and nitrogen-isotope analyses.

\begin{tabular}{ccc}
\hline $\begin{array}{c}\text { Depth } \\
\text { (centimeter) }\end{array}$ & $\begin{array}{c}\boldsymbol{\delta}^{\mathbf{1 3}} \mathbf{C} \\
\text { (per mil) }\end{array}$ & $\begin{array}{c}\boldsymbol{\delta}^{\mathbf{1 5}} \mathbf{N} \\
\text { per } \mathbf{~ m i l})\end{array}$ \\
\hline & & \\
Williams Lake & & \\
910 & -23.9 & -2.37 \\
957 & -25.8 & -2.07 \\
997 & -25.0 & -2.52 \\
1034 & -24.7 & -2.23 \\
1072 & -24.5 & -2.58 \\
1132 & -26.3 & -1.02 \\
1211 & -26.5 & 0.77 \\
1260 & -26.0 & 1.93 \\
1300 & -25.4 & 1.42 \\
1339 & -26.6 & 1.58 \\
1436 & -27.1 & 2.04 \\
1460 & -28.1 & 2.83 \\
1505 & -30.2 & 3.13 \\
1538 & -34.2 & 3.93 \\
1564 & -31.4 & 3.40
\end{tabular}

\begin{tabular}{ccc}
\hline $\begin{array}{c}\text { Depth } \\
\text { (centimeter) }\end{array}$ & $\begin{array}{c}\boldsymbol{\delta}^{\mathbf{1 3}} \mathbf{C} \\
\text { (per mil) }\end{array}$ & $\begin{array}{c}\boldsymbol{\delta}^{\mathbf{1 5}} \mathbf{N} \\
\text { (per } \mathbf{~ m i l})\end{array}$ \\
\hline 610 & -30.3 & 3.25 \\
640 & -30.2 & 2.64 \\
709 & -29.7 & 1.80 \\
749 & -30.9 & 2.44 \\
789 & -32.5 & 2.76 \\
826 & -32.2 & 2.47 \\
866 & -32.6 & 1.83 \\
899 & -33.2 & 1.79 \\
931 & -33.7 & 1.08 \\
956 & -33.6 & 2.75 \\
& & \\
Spectacle Lake & & \\
2 & -24.1 & 0.14 \\
62 & -22.2 & -0.47 \\
153 & -22.2 & 1.08 \\
183 & -21.9 & 0.80 \\
334 & -22.5 & 1.05 \\
374 & -22.6 & 1.53
\end{tabular}

Shingobee Lake

$\begin{array}{ccc}14 & -31.4 & 0.79 \\ 48 & -31.4 & 2.74 \\ 88 & -31.2 & 2.57 \\ 128 & -30.5 & 2.91 \\ 168 & -30.5 & 2.44 \\ 205 & -30.0 & 1.51 \\ 230 & -29.8 & 3.66 \\ 260 & -30.2 & 3.39 \\ 304 & -29.5 & 3.80 \\ 340 & -29.5 & 3.15 \\ 430 & -29.7 & 2.93 \\ 470 & -29.9 & 2.24 \\ 510 & -30.2 & -0.88 \\ 530 & -30.3 & 1.51 \\ 570 & -30.9 & 1.80\end{array}$

Lake Pepin, core D2

$\begin{array}{ccc}10 & -27.6 & 2.93 \\ 42 & -27.3 & 4.29 \\ 62 & -27.0 & 4.15 \\ 78 & -26.7 & 5.54 \\ 94 & -27.2 & 6.19 \\ 118 & -27.2 & 4.04 \\ 142 & -28.2 & 5.06 \\ 166 & -28.1 & 4.63 \\ 198 & -28.2 & 3.80 \\ 230 & -27.8 & 9.93 \\ 258 & -28.2 & 11.97\end{array}$

Lake Pepin

long core

$\begin{array}{ccc}12 & -28.2 & 6.05 \\ 52 & -28.0 & 4.94 \\ 92 & -27.8 & 5.34 \\ 132 & -29.0 & 5.79 \\ 172 & -29.6 & 5.50 \\ 212 & -29.5 & 4.98 \\ 252 & -29.4 & 5.01 \\ 287 & -28.8 & 5.08 \\ 442 & -28.9 & 4.56 \\ 482 & -29.2 & 4.61\end{array}$


Appendix 3. Results of carbon-and nitrogen-isotope analyses.-Continued

\begin{tabular}{ccc}
\hline $\begin{array}{c}\text { Depth } \\
\text { (centimeter) }\end{array}$ & $\begin{array}{c}\boldsymbol{\delta}^{\mathbf{1 3}} \mathbf{C} \\
\text { (per } \mathbf{~ m i l )})\end{array}$ & $\begin{array}{c}\boldsymbol{\delta}^{\mathbf{1 5}} \mathbf{N} \\
\text { (per } \mathbf{~ m i l})\end{array}$ \\
\hline 522 & -29.6 & 5.05 \\
559 & -29.7 & 3.90 \\
602 & -28.8 & 4.28 \\
642 & -28.6 & 4.60 \\
682 & -28.5 & 3.44 \\
722 & -28.7 & 1.43 \\
772 & -28.8 & 4.02 \\
812 & -29.0 & 4.07 \\
852 & -29.1 & 4.92 \\
892 & -29.0 & 4.56 \\
932 & -29.2 & 3.32 \\
972 & -29.8 & 3.03 \\
1012 & -29.7 & 3.73 \\
1052 & -30.0 & 2.38 \\
1092 & -29.7 & 2.86 \\
1132 & -30.1 & 2.72 \\
1172 & -29.9 & 2.93
\end{tabular}

Pickerel Lake

$\begin{array}{ccc}39 & -24.43 & 4.19 \\ 119 & -23.41 & 3.76 \\ 198 & -24.32 & 4.22 \\ 279 & -24.16 & 2.98 \\ 359 & -24.91 & 3.57 \\ 439 & -23.66 & 3.24 \\ 539 & -24.57 & 2.67 \\ 619 & -25.53 & 3.86 \\ 779 & -24.19 & 3.45 \\ 909 & -24.34 & 3.42 \\ 989 & -24.34 & 2.89 \\ 1120 & -24.93 & 2.99 \\ 1230 & -23.66 & 3.21 \\ 1335 & -24.61 & 2.26 \\ 1390 & -26.02 & 2.89 \\ 1450 & -26.48 & 3.33 \\ 1494 & -26.67 & 2.25 \\ 1569 & -30.95 & 2.05 \\ 1622 & -30.43 & 3.45 \\ 1695 & -24.73 & 2.02\end{array}$

Blacktail Pond

$\begin{array}{lll}101 & -25.5 & -0.35 \\ 121 & -25.3 & 0.45 \\ 141 & -24.6 & 0.77\end{array}$

Slough Creek Pond

\begin{tabular}{|c|c|c|}
\hline $\begin{array}{c}\text { Depth } \\
\text { (centimeter) }\end{array}$ & $\begin{array}{c}\delta^{13} \mathrm{C} \\
\text { (per mil) }\end{array}$ & $\begin{array}{c}\delta^{15} \mathrm{~N} \\
\text { per mil }\end{array}$ \\
\hline 161 & -24.5 & -0.30 \\
\hline 181 & -24.1 & 0.02 \\
\hline 201 & -24.4 & -0.41 \\
\hline 221 & -24.8 & 0.31 \\
\hline 241 & -25.1 & 0.39 \\
\hline 281 & -27.4 & -0.29 \\
\hline 301 & -26.1 & -0.59 \\
\hline 321 & -26.0 & 0.25 \\
\hline 341 & -26.4 & -0.13 \\
\hline 361 & -26.6 & -0.22 \\
\hline 381 & -26.9 & 0.39 \\
\hline 401 & -26.9 & 0.26 \\
\hline 421 & -28.5 & 0.59 \\
\hline 441 & -27.2 & 0.44 \\
\hline 461 & -27.2 & -0.35 \\
\hline 481 & -28.6 & -0.20 \\
\hline 501 & -28.7 & -0.95 \\
\hline 521 & -28.2 & -0.32 \\
\hline 541 & -28.0 & -0.24 \\
\hline 561 & -28.3 & 0.12 \\
\hline 581 & -27.4 & 0.36 \\
\hline 609 & -25.0 & -0.24 \\
\hline 629 & -29.1 & 0.39 \\
\hline 648 & -29.1 & 0.36 \\
\hline 669 & -29.6 & -0.01 \\
\hline 691 & -27.4 & 0.43 \\
\hline 701 & -26.7 & -0.11 \\
\hline 731 & -26.6 & 0.48 \\
\hline 751 & -30.1 & 0.32 \\
\hline 771 & -30.5 & 0.48 \\
\hline \multicolumn{3}{|l|}{ Slough Creek Pond } \\
\hline 16 & -30.6 & -0.96 \\
\hline 34 & -30.9 & -1.40 \\
\hline 54 & -32.0 & -0.91 \\
\hline 74 & -30.0 & -0.30 \\
\hline 91 & -30.2 & -1.53 \\
\hline 111 & -31.3 & -1.22 \\
\hline 131 & -30.4 & -1.46 \\
\hline 145 & -29.9 & -1.35 \\
\hline 174 & -28.2 & -1.33 \\
\hline 194 & -29.0 & -1.71 \\
\hline 214 & -28.5 & -1.70 \\
\hline 234 & -28.4 & -1.77 \\
\hline
\end{tabular}


Appendix 3. Results of carbon-and nitrogen-isotope analyses.-Continued

\begin{tabular}{ccc}
\hline $\begin{array}{c}\text { Depth } \\
\text { (centimeter) }\end{array}$ & $\begin{array}{c}\boldsymbol{\delta}^{\mathbf{1 3}} \mathbf{C} \\
\text { (per mil) }\end{array}$ & $\begin{array}{c}\boldsymbol{\delta}^{\mathbf{1 5}} \mathbf{N} \\
\text { (per } \mathbf{~ m i l} \text { ) }\end{array}$ \\
\hline 265 & -27.8 & -1.04 \\
285 & -28.0 & -1.34 \\
305 & -28.1 & -1.73 \\
340 & -29.0 & -1.39 \\
355 & -28.3 & -0.93 \\
375 & -29.2 & -0.58 \\
395 & -29.2 & -0.78 \\
411 & -28.9 & -1.53 \\
435 & -27.8 & -1.68 \\
455 & -26.0 & -1.39 \\
475 & -29.0 & -0.30 \\
495 & -28.7 & -1.18
\end{tabular}

\begin{tabular}{ccc}
\hline $\begin{array}{c}\text { Depth } \\
\text { (centimeter) }\end{array}$ & $\begin{array}{c}\boldsymbol{\delta}^{\mathbf{1 3}} \mathbf{C} \\
\text { (per mil) }\end{array}$ & $\begin{array}{c}\boldsymbol{\delta}^{\mathbf{1 5}} \mathbf{N} \\
\text { per } \mathbf{~ m i l )}\end{array}$ \\
\hline 619 & -25.1 & 1.95 \\
639 & -24.7 & 1.88 \\
659 & -25.1 & 0.21 \\
679 & -25.0 & 0.59 \\
699 & -27.0 & 0.37 \\
719 & -26.1 & 1.43 \\
739 & -25.1 & 1.41 \\
759 & -25.5 & 1.75 \\
779 & -24.8 & 0.53 \\
799 & -24.7 & 1.58 \\
819 & -24.1 & 1.32 \\
839 & -24.9 & 1.94 \\
859 & -24.7 & 1.73 \\
879 & -25.0 & 1.84 \\
899 & -24.6 & 1.06 \\
919 & -24.7 & 1.02 \\
939 & -25.7 & 2.66 \\
959 & -26.7 & 3.97 \\
979 & -25.5 & 2.20 \\
999 & -25.7 & 2.72
\end{tabular}

Trail Lake

$\begin{array}{ccc}1 & -25.5 & -4.14 \\ 19 & -24.7 & -4.38 \\ 39 & -24.3 & -3.98 \\ 59 & -24.5 & -2.48 \\ 79 & -25.9 & -2.84 \\ 99 & -25.7 & -2.99 \\ 119 & -25.9 & 0.62 \\ 139 & -25.6 & 0.57 \\ 159 & -26.7 & 0.97 \\ 179 & -25.6 & 0.64 \\ 199 & -25.7 & 0.56 \\ 219 & -25.7 & 1.86 \\ 239 & -26.4 & 2.26 \\ 259 & -25.9 & 2.14 \\ 279 & -25.8 & 3.21 \\ 299 & -26.9 & 2.12 \\ 319 & -27.6 & 1.97 \\ 339 & -26.3 & 2.11 \\ 359 & -26.5 & 2.55 \\ 379 & -26.3 & 2.05 \\ 399 & -27.0 & 3.35 \\ 419 & -26.8 & 1.57 \\ 439 & -26.6 & 2.16 \\ 459 & -26.6 & 2.78 \\ 479 & -26.7 & 1.39 \\ 499 & -26.2 & 1.93 \\ 539 & -26.1 & 1.15 \\ 559 & -25.8 & 0.88 \\ 579 & -25.5 & 1.98 \\ 599 & -25.3 & 0.66\end{array}$

Cygnet Lake

$\begin{array}{ccc}0 & -28.3 & 2.27 \\ 20 & -28.2 & 1.39 \\ 40 & -27.8 & 1.77 \\ 60 & -28.1 & 2.65 \\ 80 & -26.6 & 1.59 \\ 100 & -25.3 & 2.38 \\ 120 & -23.9 & 1.44 \\ 141 & -23.4 & 1.90 \\ 154 & -22.8 & 2.63 \\ 159 & -21.9 & 1.66 \\ 180 & -21.8 & 0.37 \\ 202 & -21.5 & 1.97 \\ 220 & -21.2 & 1.64 \\ 252 & -21.5 & 3.14 \\ 270 & -22.9 & 2.11 \\ 292 & -23.7 & 2.28 \\ 315 & -22.5 & 2.18 \\ 330 & -22.3 & 3.55 \\ 367 & -21.6 & 3.53 \\ 382 & -20.3 & 3.06 \\ 400 & -21.6 & 2.32 \\ 420 & -21.5 & 1.33\end{array}$


Appendix 3. Results of carbon-and nitrogen-isotope analyses.-Continued

\begin{tabular}{ccc}
\hline $\begin{array}{c}\text { Depth } \\
\text { (centimeter) }\end{array}$ & $\begin{array}{c}\boldsymbol{\delta}^{\mathbf{1 3}} \mathbf{C} \\
\text { (per } \mathbf{m i l})\end{array}$ & $\begin{array}{c}\boldsymbol{\delta}^{\mathbf{1 5}} \mathbf{N} \\
\text { (per } \mathbf{~ m i l})\end{array}$ \\
\hline 440 & -21.2 & 0.90 \\
460 & -21.1 & 0.47 \\
480 & -18.0 & 1.80 \\
504 & -17.5 & 1.08 \\
526 & -21.4 & 1.71 \\
\hline
\end{tabular}

